\title{
DIVERSIFICATION OPPORTUNITIES AND EFFECTS OF ALTERNATIVE POLICIES ON COSTA RICAN COFFEE FARMS
}

\author{
By \\ JOHN LEWIS BIEBER
}

\begin{abstract}
A Dissertation PRESENTED TO THE GRADUATE COUNCIL OF THE UNIVERSITY OF FLORIDA

IN PARTLAL FULFILLMENT OF THE REQUIREMENTS FOR THE DEGREE OF DOCTOR OF PHILOSOPHY
\end{abstract}


31.42

B586d

AQRI.

CULTURAL

LIBRARV

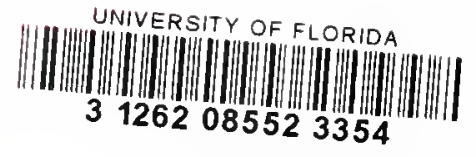


ACKNOWLEDGENTS

The author wishes to express his sincere appreciation to Dr. W. W. McPherson, Chairman of the Supervisory Comnittee, for his guidance and supervision throughout all phases of this research and for his valuable suggestions and criticisms in preparing this manuscript.

Thanks are also due Dr. C. E. Murphree, Dr. C. W. Fristce, Dr. K. C. Gibbs and Dr. L. H. Myers for reviewing the manuscript and offering assistance. The author also wishes to thank Dr. H. L. Fupenoe, Director of the University of Florida's Center for Tropical Agriculture, for his assistance in obtaining funds for support of the project. The assistance of the University of Florida's Computing Center is recognized and appreciated. The author also wishes to express thanks to Mr. D. W. Parvin for his aid in interpleting the computer manuals.

Special thanks are also due numerous peopie in Costa Rica who graciously supplied information and insights necessary to the completion of ihis wark. The oficina del café under tho direction of sr. Alvaro Castro Jiménez supplied transportation, office facilities, and technical assistance. The author dependicd heavily on the advice of lng. Hugo Castro, Ing. Rogelio Acosta and log. Ecimin Marín in the inicial phases of the study.

The cooperation of the Ertension Service of the Costa isica Ministry of Agricul bure is also appreciated. Acknowledgnent and thanks ale due the and people who supplied input-uttput information. 
Addiional assistance was given by others including Carlos Arroyo, Hester Barres, James Ross, Russel Desrosiers, Oscar Benavides, Robert F. Voertman, J. Robert Hunter, and Ernesto Sanarrusia. Special thanks are also due Miss Linda DiDuonni and Mrs. Sandi Davis for typing the first draft and to Mrs. Lillian Ingenlath for typing the final manuscript. 
TABLE OF CONTENTS

Page

ACKNOWLEDGMENTS . . . . . . . . . . . . . . . .

LIST OF TABLES

$\vee \mathbf{i}$

INTRODUCTION ........................... I

An Economic Background . . . . . . . . . . . . 1

The importance of Coffee to Costa Rica . . . . . . 3

The Marketing Situation for Coffee . . . . . . . 5

The Pros and Cons of Diversification . . . . . . . 9

Approaches and Attitudes toward Diversification . . . 12

The Problem and Objectives . . . . . . . . 17

SLOPE AND METHOD OF STUDY . . . . . . . . . . . . . . 20

Selection of Areas and Farms . . . . . . . . . 20

Description of Farms Studied . . . . . . . . . 22

Palmares-San Ramón . . . . . . . . . . 22

Alajuela............. . . . . . . 26

Acosta............... . . . . 28

The Linear Programing Model . . . . . . . . . 30

The Enterprises and Restraints . . . . . . . . . 41

The Sources of the Budgets . . . . . . . . . . 48

Assumptions of the Model . . . . . . . . . . 55

PESULTS . . . . . . . . . . . . . . . 57

optimal Cropping Plans . . . . . . . . . 57

Farm l................... . . 57

Farm 2. . . . . . . . . . . . . 58

Farm 3................. . . 58

Farm 4 ................ . . 59

Farm 5. . . . . . . . . . . . . . . 60

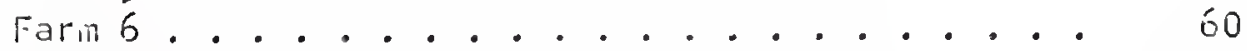

$\operatorname{Farm} 7 . .0 .0 .0 .0 .0 .061$

Farm 8........................... 62

Farm 9................. . . . 62

Fam $10 . .0 .0 .0 .0 .0 .0 .063$

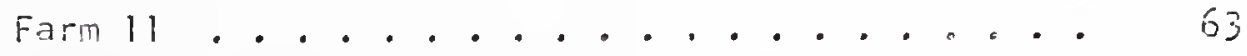




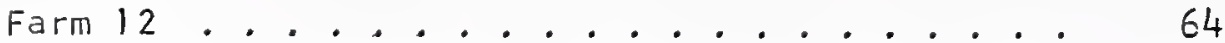

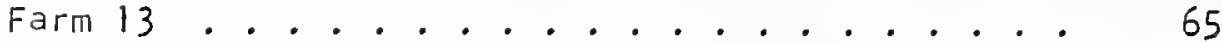

Farm $14 . . .0 . .0 . .0 .066$

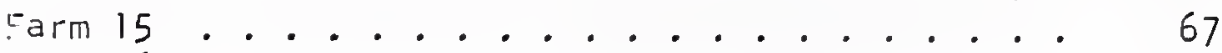

Farm $16 . .0 . .0 .0 .0 .0 .068$

Policy Analysis................. 69

Education for Better Farm Management . . . . 69

Taxation or Price Reduction ........ 75

Payments for Coffee Removal ........ . 81

Price Differentiation ....... . . 87

Reduction of Credit .......... 90

Movement of Labor ............ . 93

Extra Credit . . . . . . . . . . 98

Subsidies for Al ternatives........... 101

Stability of Alternative Crops ........ 103

Comparative Costs of Coffee Removal ........ 110

SUMMARY AND CONCLUSIONS .................................. 134

Effects of Improved Resource Allocation...... 134

Effects of Taxes or Price Declines ........ 136

Effects of Credit Reduction .......... . 137

Effects of Price Differentiation ........ 138

Effects of Increased Credit........... 139

The Choices of Alternative Crops ........ . 140

Comparative Costs of Coffee Removal ....... . 143

Potential Effects of Technological Advances

in Coffee Production ........... 144

The Qualifications of an Acceptable filternative... 145

Giversification Versus Production Control..... 146

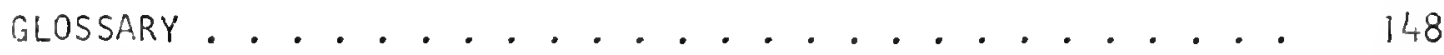

APPENDIX...................................... 149

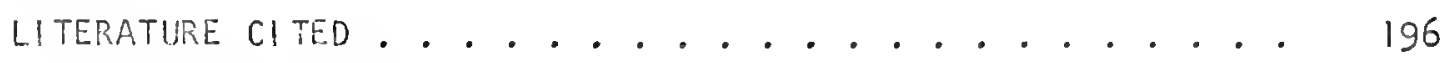

BIOCRAPHICAL SKETCH .................... 202 


\section{LIST OF TABLES}

Table

Page

1. Partial matrix of coffee selling activities ...

2. Comparisons between reported and optimal incomes and coffee output . . . . . . . .

3. The effects of improving coffee production technology on coffee production and income

4. Comparisons of optimal incomes and coffee outputs with traditional versus new enterprises on farms in Alajuela and Acosta ....

5. Optimal coffee production with specified price declines per fanega of coffee......

6. Optimal manzanas in coffee with specified price declines per fanega of coffee.........

7. Optimal net farm income with specified price declines per fanega of coffee.........

8. Alternative crops increased first by declines in coffee prices . . . . . . . . . .

9. Coffee production with annual payments for coffee removal ...............

10. Net farm income with annual payments for coffee removal

11. The alternative crops increased first by annual payments for coffee removal . . . . .

12. Comparisons of income and coffee production for differentiated prices versus single prices . . . . . . . . . . . .

13. Dptimal coffee production with various levels of reduced credit ..........

14. Optimal net income with various levels of reduced credit 
15. Optimal manzanas in coffee with various levels of reduced credit... . . . . . . . . 94

16. Marginal returns to credit with various levels of reduced credit.............

17. Optimal family income with and wi thout offfarm employment opportunities........

18. Optimal farm income and the reduction of permanent labor . . . . . . . . . . .

19. Effect of additional credit on income and coffee production.............

20. Optimal farm outputs of various crops on Alajuela farms given base capital and credit constraints and extra credit equaling $\xi 400$ and $\xi 2,000$ per manzana .....

21. Optimal output of various crops on Acosta farms with high fruit prices given base capital and credit and extra credit equaling $\$ 400$ and \$2,000 per manzana ...........

22. The effect of a blackberry subsidy on optimal coffee output . . . . . . . . . . . .

23. The effect of a strawberry subsidy on optimal coffee output...............

24. Relationships between long-term interest rates and manzanas planted to limes . . . . .

25. Lime prices and lime production ........ 106

26. Prices of oranges necessary to initiate orange production on farms in Alajuela and Acosta . . . . . . . . . . . .

27. Alternative methods of reducing coffee output on farm l..............

28. Comparative costs of various methods of coffee output reduction on farm $2 . . . .$. .

29. Alternative methods of reducing coffee output on farm 3

30 .

Alternative methods of reducing coffee output on farmi 4 
31. Comparative costs of various methods of reducing coffee output on farm 5 . . . . .

32. Comparative costs of various methods of reducing coffee output on farm $6 . . . .116$

33. Comparative costs of various methods of reducing coffee output on farm 7 ......

34. Comparative costs of various methods of reducing coffee output on farm 8 ......

35. The comparative costs of various methods of reducing coffee output on farm $9 . . .$. .

36.

The comparative costs of various methods of reducing coffee output on farm $10 \ldots .$.

37. The comparative costs of various methods of reducing coffee output on farm ll ....

The comparative costs of various methods of reducing coffee output on farm $12 . .$. .

The comparative costs of various methods of reducing coffee output on farm 13 , given high fruit prices...........

40. The comparative costs of various methods of reducing coffee output on farm 14 , given high fruit prices...........

41. The comparative costs of various methods of reducing coffee output on farm 15 , given high fruit prices...........

42. The comparative costs of various methods of reducing coffee output on farm 16 , given high fruit prices..........

43. The comparative costs of various methods of reducing coffee output on farm 13 , given low fruit prices ..........

44. The comparative costs of various methods of reducing coffee output on farm 14 , given low fruit prices ...........

45. The comparative costs of various methods of reducing coffee output on farm 15 , given low fruix price 
46. The comparative costs of various methods

of reducing coffee output on farm 16 ,

given low fruit prices .......... 


\section{NTRODUCTION}

\section{An Economic Background}

Costa Rica is a small country in Central America with a population of 1.6 million people living on an area of 19,700 square miles (46, p. 11). The economy is dominated by agriculture which amployed over 56 percent of the active work forcs in 1963 (45, p. 13). In addition, agricultural products accounted for approximately 30 percent of the gross national product in 1966 and about 80 percent of the value of Costa Rica's exports (17, P. 3). Allegar described costa Rica as a nation of small farmers (3, 2.33$)$. This characterization does not mean that land is evenly distributed among the population, since farms of over 100 manzanas represent only 10.5 percent of all farms and cover 70 percent of the total farmland area (23, p. 46). Nevertheless, the land distribution figures must be interpreted with a realization that many iarge farms are in remote areas and that, except for sugarcane and bananas, the intensively grown crops are dominated by small and middle-sized fams.

In recent years, Costa Rica enjoyed the highest per capita income in Central America. The estimated gross national product per person in 1965 was $\$ 415$ compared to an average of \$303 for a!l of Contral America (55, p. 3).

In recent years costa kica has had a balance of payments problem. Foreign debts have had to be continually romegotiated. From 1950 to 
1967 the value of exports of coffee, bananas, cocao, cotton, beef, and sugar increased from 592.1 to $702.8 \mathrm{million}$ colones (56, p. 34 ). While the value of exports has increased despite unfavorable price trends, the value of imports has increased at a much faster rate. The value of exports exceeded the value of imports by 24.3 percent in 1967 and by 12.2 percent in 1968 (24).

Froduction of the basic food crops has exhibited erratic growth since 1950. Corn imports exceeded exports in 1951, 1954, 1956, 1959, 1964 and 1966. Per capita consumption of corn in 1966 was below the 1950 level (56, p. 42). Rice production has almost tripled since 1950, with a stronger upward trend occurring after 1958. While the change is largely due to an increased acreage, the average yields have increased since 1955 (56, p. 5). Per capita conslimption of rice has increased. Bean production has also increased significantly, doubling the 1950 output in 1967. However, net imports of beans occurred in 1951, 1956, 1957, 1959, 1961, 1962 and 1964. Per capita consumption has increased 25 percent since 1950 (56, p. 28).

The Costa Rican population increased from 1,028,175 in 1955 to $1,648,815$ in $1960(15, p .2)$, an annual average increase of more than 4 percent. While population growth increases the demand for food, this demand is also increased by a rise in per capita incomes. If food output is to keep pace with the demands of both population and income growth, further changes in inputs and technology will be required (13). The allocation of scarce foreign exchange to food imports limits the ability of a developing nation to furchase capital goods needed for conomic growth (48, p. 5).

Another probiem facing Costa Rican plarners is public finances. 
The costs of governmental services are increasing. Education is an example (55, p. 33). Schools are being expanded but more and more children crowd them. With over 35 percent of the population under ten years old, education is costly (19, p. 47). Rapid population growth slows occupational changes (1).

Thus while the costa Rican economy has given the nation the highest per capita income in Central America and supports the most advanced social and educational programs in the region, it faces demanding requirements if it is to continue to grow.

\section{The Importance of Coffee to Costa Rica}

Coffee is Costa Rica's leading agricultural commodity, the chief export crop, and a major user of agricultural credit and labor. Coffee has historically accounted for 17 to 26 percent of the value of agricultural output (54, p. 37). Despite a long history of production, coffee output has increased markedly in recent years. From 1955 to 1963 coffee output was doutled. Yields increased 27 percent while acreage increased over 58 percent (53, p. 10). Considerable effort was put into research and extension work which emphasized the use of modern inputs in coffee production. Higher coffce prices in the 1950's encouraged the expansion of coffee onto new lands. The modernization of coffee production is indicated by the fact that in 1963, 27 percent of the farms reported fertilizer use on 53 percent of the land planted to coffee (23, p. 176). Fertilizer responses gave 18 to 233 percent increases in coffee yields in triels running from 1952 to 1957 (69, p. 60). Since 1963. production iricreases indicate an even lerger use of off-farm inputs. In 1967, coffee output 
was more than three times the average output in the 1948 to 1952 period (29, p. 63). Thus coffee production has led in a change from traditional toward modern farming methods.

Coffee is the major source of foreign exchange for costa Rica. It accounted for 38.9 percent of total value of exports in 1966, 41.2 percent in 1965 and 42.2 percent in 1964 (15, p. 13). Thirty percent of the economically active population is associated with the coffee industry (54, p. 37). This underestimates coffee's importance as a source of wage earnings since many children harvest coffee and are not considered part of the economically active population. The harvest season usually coincides with school vacations. Also, earnings from coffee picking greatly exceed other farm labor earnings. Another benefit that comes from coffee production is soil conservation. A weli-cared-for coffee planting protects the soil from driving rain and contour ridges that s!ow runoff are permanent and reinforced with woody root systems. Much of the land utilized by coffee is unsuitable for annual cropping unless very elaborate terracing is used (67).

Lastly, coffee is a source of tax revenue. Taxes of $\$ 0.45$ per quintal of exported coffee, $\$ 2.00$ per quintal of coffee consumed internally, and $\$ 0.20$ per fanega of coffee fruit processed at the beneficios support the operations of the oficina del café. In addition, an advalorum tax contributes to the national treasury. This advalorum tax is graduated in the following manner: 10 percent if the average price exceeds $\$ 2.50$ per quintal, $7 \frac{1}{2}$ percent if the àverage price falls between $\$ 40.00$ and $\$ 42.50$ per quintal, 5 percent if the average price falls between $\$ 37.50$ and $\$ 40.00$ per quintal, and $2 \frac{1}{2}$ percent if the average price fallis between $\$ 35.00$ and $\$ 37.50$ per 
quintal. No advalorum tax is paid if the price falls below $\$ 35.00$ per quintal (54, p. 56).

Declines in coffee prices are burdensome to governments which depend upon coffee earnings for foreign exchange and tax revenue (30, p. 15). This is particularly true in Costa Rica where a 14 percent decline in price resulted in a 57 percent loss in tax revenue per quintal and a 3 percent decline in price resulted in a 53 percent loss in tax revenue per quintal in the marketing years from 1965-66 to 1966-67 to 1967-68. The price decline from 1966 to 1968 brought about a drop in tax revenue estimated at 24 million colones ( 55 , p. 10)

\section{The Marketing Situation for Coffee}

Historically, coffee production has gone through highly cyclical price periods. Prices fluctuated in a cyclical pattern accentuated by pariodic unplanned changes in supply caused by unfavorable weather conditions in Brazil (32, p. 454). When drought and frost cut Brazil's output the price would rise. This high price encouraged renovation of old coffee orchards and the planting of rew ores. Later, when recovery of damaged groves occurred, output surpassed the earlier level. Prices then were pushed to new lows causing abandonment or neglect of coffee farms until unfavorable weather again stimulated high prices. Over the years, there have been short rericds of shortage and high prices followed by long periods of surplus and low prices (59, p. 8). These drastic price fluctuations stimulated coffee producers to seek remedial schemes. The first of these was a Brazilian law blocking new plantings in 1902. Foliticaliy 
unpopular, this law was repealed and followed by valorization schemes with which large quantities of coffee were purchased and held off the market (32, p. 456). Brazil borrowed from British banks to make coffee purchases in 1906, 1917, 1921 and 1927. Larger and larger crops were encouraged which became more and more difficult to store. Brazil burned over 78 million bags of surplus coffee from 1931 to $1944(73$, p. 423).

Coffee production in other Latin American countries expanded in response to Brazil's price supporting activities. Growth elsewhere caused Brazil to market a smaller percentage of the world coffee (73, p. 425)

International agreement to control coffee output was first attempted in Bogatá in 1936. Later, the Inter-American Coffee Agreement was signed by 14 producing countries and the United States. Selling quotas werc established and the agreement lasted from 1941 to $1943(73$, p. 423). In 1957, coffee producing nations agreed upon a voluntary system of export regulation. This agreement failed to check the downward price movement (59, p. 13). Finally, the International Coffee Agreement received the support of 46 producing and consuming countries in 1963. By chance, a severe frost cut the Brazilian output that year and, as a result, quotas were increased to give help to the coffee consumers as prices rose (59, p. 14). The demand for coffee is believed to be inelastic with respect to price. If this is true, a free-market solution would rosult in lower gross income to producers than would occur if output. Were limited by some kind of a cartel arrangement. Econonists generally vicu trate agreenients with a skeptic eye. Both experiches and theory show that, with 
price maintenance at or above a free-trade level, pressures and temptations arise to break or by-pass the agreement since high prices tend to encourage more production (37, p. 108).

Nevertheless, the International Coffee Agreement has reduced price fluctuations and is considered to be effective enough to justify extension for five more years from 1968 (8, p. 188). However, the reduction in world output from 1965-66 to 1966-67 occurred mostly in Brazil where weather has historically caused wide production variation. The 1963 Agreement was concerned with regulating sales and made no attempt to regulate production.

In 1968, a new article was written into the International coffee Agreement setting up the Diversification Fund (34). This change provides for compulsory payments (U. S. \$0.60 per bag in excess of 100,000 bags) into the Fund. This acts as a tax on coffee. Extra incentive is given to coffee producing nations to devise crop diversification projects. Eighty percent of the compulsory payments can be used within the producing country on approved projects. If not used domestically, the unused payment mist be paid to the fund in freely convertible currency. Thus each country will be motivated to devolop local diversification projects by the desire to conserve scarce foreign exchange.

Producing countries have used different programs to check coffee output. As mentioned earljer, Brozil first attempted to control output in 1902 with a law prohibiting new plantings. More recently payments have been made for coffee removal (60). Participation in the frogram has been voluntary, with 648 million coffee trees pulled out from Jure, 1962 to December, 1965. Plans had called for the removal 
of two billion trees and part of the lack of response was blaned on inflation which lowered the value of the fixed payments from $\$ 0.04$ to \$0.01 per tree. The effect on coffee output was small. The program included no restriction on planting. In Colombia, International Development Bank (IDB) loans have been used to further credit, infrastructure, education, comercialization and industrialization of alternative products. In Mexico, rubber, citrus and avocado plantings are being promoted in a program directed at the small coffee producer (27). In El Salvador, sugar, corn and rice production has been expanded. Modern corn and rice production gave returns reported to range between $\$ 3.00$ and $\$ 7.50$ per $\$ 1.00$ spent on new inputs. Nevertheless, the expansion of cereals was accompanied by a reduction in cotton and beans, rather than coffee (74). In Guatemala, pilot tests of tea, citrus, dairy and oil palm have been initiated. Over $\$ 1.9$ million in foreign money has been invested in the program. Total costs surpassed $\$ 5.8$ million invested on 282 farms covering 3,900 hectares (6). Guatemala also is developing a rubber industry. In 1965, rubber was planted on 26,000 acres. Projections estimate gross returns of $\$ 24$ million from 80,000 acres (75).

In Costa Rica, credit for new coffee plantings has been restricied. In addition, the Universidad de Costa Rica, the U. S. AlO Mission, the University of Florida, and the Centro para la Promoción de Exportaciones and Inversiones cooperated in a series of obscrvation trials in six locations scattered throughout the wastern part of the coffee giowing region. The municipality of Turrialba has initiated a regional diversification program with the Instituto lnteramericano de Ciencas Agrícolas. Financial support from the oficina del Café and 
the Agency for International Development ( $A \mid D)$, plus technical assistance from the Instituto Interamericano de Ciencas Agrícolas, the Peace Corps, and the Ministerio de Agricultura, makes this a truly cooperative venture. The emphasis is primarily on research with a rapid follow-up of pilot commercial plantings. The project began with basic studies of fast growing trees, Tilapia fish ponds, and macadamia nut production. The stated main purpose of the project was to institutionalize an attitude of dynamic change (9). While it is still too early to evaluate results, leaders in another municipality have talked of imitating Turrialba with a diversification project of their own.

In sumary, a review of the literature on Latin American coffee diversification showed more discussion and hypothesizing than practical results.

\section{The Pros and Cons of Diversification}

There has been much discussion of diversification in recent years as a method to foster economic development. In a comprehensive study, Dalrymple (22) has compared monoculture and diversification. The advantages of moncculture include the following:

1. In sone cases the monoculture crop has a Glear comparative advantage both at domestic and international levels. The finencial gap between the monoculture crop and next best alternative has been found to be too wide to permit rational change.

2. It may be easier to raise yields to give higher returns f:om an established crop than to press for more complex cropping systems. The short..run returis to incraased specializaticn with economies of 
scale may be quite high. The new kncwledge arid skills required to improve production of an existing crop may be easier to learn than the technical requirements of a totally new crop.

3. Monoculture is generally focused on export crops which provide a developing country with needed foreign exchange and an easily administered tax system.

4. Certain crops have more prestige and social status than others.

The disadvantages of monoculture bring out accompanying economic difficulties:

1. Producers under monoculture are subject to high risk induced by technical change and insect and disease problems. This is often labeled "putting a lot of eggs in one basket."

2. Because many of the mcnoculture crops are perennials, a production lag may follow a decision to increase output. By the time the crop comes into production considerable investment has already been made. Excessive reaction to favorable price situations may occur when this lag follows a major change in rasource allocation. Readjustment of suppiy to face'a lowered price will be sluggish cven in the face of losses since marginal costs may be easily covered.

3. The low price elasticity of demand for coffee results in sharp, short-term price fluctwations caused by wather and biological iactors. The resultirg high prices in the short run may trigger ir.peversib!e investmonts. These investments plus technological advances can be experted to increase supply ahi le demand is not likely to increase faste! thon population glowth. As a result, prices are Bxbecied to weiken over tima. 
4. Trade agreements limit sales to key markets and therefore increase both price and gross returns for the commodity with an inelastic demand. Unless each producing country takes actions to correct the internal distortions of high incentives for the commodity covered by trade agreements, an imbalance encouraging overproduction of that commodity will result $(53$, p. 9).

The advantages and disadvantages of diversification are roughly the inverse of those of monoculture. Diversification may be advantageous if it more fully utilizes labor and reduces econonic risk ( 48 , p. 24). A number of different sources of income gives protection against severe loss caused by insects, disease or bad weather conditions which may affect one particular crop but not others. Labor requirements may be spaced in such a way that one crop uses labor when another has a slack work period. Shifting from an export crop to food crops can load to improved nutritional levels, especially if more fruits and vegetables are introduced into the diet. Also, import substitution may save scarce foreign exchalige (22, p. 27).

Or the other hand diversification faces certain limitations. Research has been focused on a few major export srops (22, p. 39). Without much experience or local sciertific investigation to support a new enterprise, the innovating producer facos higher uncertainties with respect to the crop response to ansyorebie factors and conditions (4), p. 1). The morket for the a? ternative arop mey not be sufficient to aboor expancing production at profitabla prices (22, p. 41). Even if a potentiai demand exisis, the marketing facilities liay not be adegiate to move the new oufput to consumers. The econ omies of scaie may result in poor efficiency as a grader number of crops are produced and volume of some rrops is reduced. This is 
particularly a hazard for a new crop introduced wi thout sufficient volume to utilize efficient processing machinery.

In cases where the estab!ished crop is a perennial, a high percentage of the costs are fixed. Therefore, replacement by an alternative requires that total costs, since all costs are variable, be considered in comparison with the variable costs in the case of the established crop. Also, costs associated with removing the old crop must be added into the cost of establishing the new enterprise. Another problem arises if a new crop uses either more o: less labor than the established crop (22, p. 38). If the labor requirement is much higher, labor scarcity may prevent adequate handling of the new crop. If much less labor is used, unemployment has social ramifications that may be prejudicial to the establishment of a new industry.

The quantity of research, extension work and information services will hise to be expanded if changes require more complex agricultural systenis (48, p. 24). Diversification projects are likely to fail on farms where administration and managemant indeguacies greatly limit the returns to coffee because the new enterprises are likely to be even more difficult io manage (27).

\section{Approaches and Attitudes towerd Diversification}

Crop diversification is defined as a movement away from monoculture with the grouing of new or additional crops (22, p. i). Hore detailed descriptions may be comflicting and the evaluation of diversification as a policy measure depenis grently upon just what meaning is used. A most restrictive definition, and one oflen thought of, is the transer of land from ricnoculture to aiternative uses. Homper, 
other resources besides land may be shifted from one use to another. Thus, diversification occurs if operating capital or labor is put to alternative use. For instance if labor or fertilizer is applied to strawberries rather than to coffee, diversification occurs. Diversification may even occur without a shift in resources or a reduction in primary crop output. This is possible if unused resources are asscciated with monocultural production. Therefore, if a farm were to begin to grow a crop of dasheen on swampy ground formerly unused, using surplus family labor and operating capital, this would be an example of diversification. Thus for the purposes of this study, diversification is defined as a positive action which reduces the relative importance of the primary crop.

Crop diversification may occur at either the farm level or the nationai levei. A recent advisory group proposed that costa Rica should concentrate diversification efforts on areas unsuited for coffee, where mechanization was feasible (68, p. 3). The program in this case would be to expand output using resources not now used to grow coffee.

Crop diversification may either expand domestically consumed crops or promote new export crops. Although import substitution is reccgnired as beneficial, planners seek to increase earnings of foreign exchange with rew exports. The export demard for a product facing a small country is often highty price elastic $(5 i, p .1)$. Thus, generally the new export crop has an advantace over donestic crops in that price will remin mure stable as oulput is expanded. The small size of the domestic market is coupled with a shortage of capital funds and modern know-how to limit diversified economic potential (16, p. 33). 
Furthermore, overproduction of basic food crops may result in government losses if high support prices are coupled with export subsidies (61)

Others suggest that domestic elops offer better diversification possibilities because benefits of technological change are passed on to the consuming countries $(66, \mathrm{p} .432)$. Since a particular good from one country has perfect or close substitutes produced in other countries, the demand curve facing each country is elastic. However, the common agricultural export crops are inclastic when the entire world market is considered since they do not have close substitutes, do not have many uses, and do not take a large share of the consumer's income (44, p. 41). After a technological change is widely adopted, the result of increased output is often lower gross revenue. In this situation, the corsumer benefits from iower prices and a higher real income.

The innovator may initiaily supply the donestic market when low early yields are compensated by high prices. Later, costs may be reduced to permit export or industrial use at much lower pirices. In addition, the scale of operations needed for new export ventures axreeds the capacity of existing producing units and marketing facilities (17, p. 12). The development of a new export ciop requires efficiency if it is to meat the estabitshed competition.

Another area of dabate coniers around the question of who should diversify. Two nearly opposite views have developed: an eficiency criterion of marginality proposes to remue the low proit producers. In opposition, a criterion of welfare seeks the removal of those least hart by shifting to alternative production. 
The removal of marginal producers is deemed desirable by both the Oficina del Café in Costa Rica and the Asociación National del Café in Guatemala (54, p. 32; 27). Fernández (27) defined marginal farms as those where costs exceed returns and also small farms where returns are low. One may note that this approach avoids antagonizing the politically influential in Guatemala as marginal farms are "liberated" for cther uses. In Costa Rica, selective credit restrictions were used to limit the expansion of coffee, particularly into areas producing low quality-low yield crops. The oficina del Café favors this policy because $i t$ helps to maintain a higher average of quality as well as to restrain production.

Newman (53, 9.14 ) has criticized the marginal producer definition for being concerned with absolute rather than comparative advariages. Small farms are unsuited for such alternatives as dairying and fruit production because they cannot take advantage of economies of scale open to large operators. Small farms also lack reserve capital or credit availability to enable them to invest in the more productive alternatives. They are less able to withstand possible loss of a new ventire. The opportunity cost associated with removing coffee includes interest charges on foregone income, which may be limiting for farms near the subsistence level of income when perennial aiternatives are considered.

Welfare considerations cannot be quantified for interpersonal comparisons. However, vaiue judgments need not be made if the level of alcernative output is used to evaluate different policies of diversification. The problem then becomes the calculation of the net costs of removal of a quanticy of coffee from production on different farms. 
If the means of production control is alternative use of land, this may be stated algebraically as follows:

$$
c_{r}=P_{c}-c_{c}-v_{a}+c_{a}+c_{s}
$$

where

$$
\begin{aligned}
c_{r}= & \text { net cost of removing one fanega of coffee, } \\
P_{c}= & \text { price of coffee, } \\
c_{c}= & \text { cost of producing one fanega of coffee } \\
v_{a}= & \text { value of alternative product produced with resources made } \\
& \text { available as coffee is reduced by one fanega, } \\
c_{a}= & \text { cost associated with producing } v_{a},
\end{aligned}
$$

and

$\mathrm{C}_{\mathrm{S}}=$ cost of removing trees producing one fanega of coffee.

Thus, the comparative advantage in coffee production may differ from the absolute advantage where $C_{r}=P_{c}-C_{c}$. If coffee is purchaseci and destroyed, the cost is higher as $C_{r}=P_{C}$.

A more general formula can be stated for calculating the unit cost of coffee removal.

$$
c_{r}=\frac{1_{1}-1_{2}}{Q_{1}-Q_{2}}
$$

where

$$
\begin{aligned}
& c_{r}=\text { net cost of coffee renoval } \\
& l_{i}=\text { net incone before change } \\
& l_{2}=\text { net incone after change } \\
& Q_{1}=\text { coffee produstion besore change } \\
& Q_{2}=\text { coffee production ofter change }
\end{aligned}
$$

Weally, diversification would seek to roduce coffee wi thout rew ducing income. However, given a frice situaticn which stimulides 
excess use of resources in coffee production, a more practical policy would attempt to minimize the costs of controlling output.

\section{The Problem and Objectives}

Although coffee is Costa Rica's most important comodity, continued dependence on that one crop is considered detrimental to prospects for economic growth. This harsh statement is supported by a political-economic situation in which the sales of coffee to the high consumption markets is now limited by international agreement. Thus if substantial growth is to be achieved, it must occur in some other segment of the national economy.

Technological changes are occurring in coffee production. These changes enable coffee to be produced at lower unit costs as modern inputs are added to traditional land and labor. The result is to increase yields. If resources are not shifted away from coffee, this increases production. The problem then arises as to which resources should be shifted to what alternative uses. Also, what policy measures wiil facilitate changes which are both efficacious and equitable?

Cne may also ask, are Costa Rica's farmers functioning as profit maximizers? Theodore schultz has claimed that in traditional agriculture farners are not only profit maximizers but that they also are quite efficient frofit maximizers (62, r. i4t). Hovever, most of the farms studied do not truiy fic the definition of traditional agriculture used by Schultz $(63, p .30)$. Cultural techniques for coffee have not remained unchanged for senerations and furthei changes are occurring (32, p. 432). Costa Rica's emphasis on primary education already has socomplished murh toward the investment in human resources 
necessary to change traditional attitudes $(63$, p. 201). Schultz has designated the human agent as the key variable in explaining differences in agriculturai productivity $(63, \mathrm{p} .17)$. The existence of experimental farms, scattered research plots, extension agents and agricultural schools also takes Costa Rica out of the category of traditional agriculture.

Costa Rica admittedly does have many traditional farmers. However, the threat of overproduction of coffee does not come from that direction. Recent yield increases indicate non-traditional behavior, while increased coffee acreage has been relatively unimportant (15, p. 21).

Schultz describes a transitional classification of agriculture between the traditional and the modern (63, p. 107). Vast,disequilibrium is said to exist with differences in marginal productivity and overuse or underuse of factors. The expariding use of fertilizers ard pest control chemicals (15, P. 7) indicates that transitional changes toward modernization are occurring in Cosca Rica.

Nevertheless evaiuating the farm case studies with respect to expertations given by Schultz's theories may be interesting. Traditional farm situations could be expected to give marginal value products near or at current prices of resources. On the other hand, transitional farn situations may put extremely high values on certain resources. Linear programming solutions may be compared wi th actual farm operations to judge the efficiency of farm decision makers. This may be of particular interest in explaining the continuance of traditional meihods with some crops wile changes occur wi th others. Specifically the objectives of this study were to evaluate form 
income opportunities from producing coffee and from alternatives and to determine the effects that selected programs would have on coffee production, resource use and incomes. At the same time, comparisons can be made of current resource use and optimal resource use to test the hypothesis that the farmers are income maximizers and that traditional economic behavior has economic motivations. In addition, the comparisons may be used to determine what changes or adjustments in farm operations wculd be profitable. 


\section{SCOPE AND METHOD OF STUDY}

\section{Selection of Areas and Farms}

Coffee is grown in Costa Rica under a wide range of climatic and ecological conditions. Three geographic areas were included in this analysis. The data were taken from a study carried cut under a University of Florida - AlD Contract in Costa Rica, No. la-261. Budgeted comparisons between coffee enterprises and leading alternatives in 12 areas are given in An Economic Analysis of Coffee Producing Areas, Costa Rica (11).

Palmares-San Ramón, Alajuela and Acosta mers the areas selected for this intensive study. This selection was based on the following criteria:

1. Coffee and alternative crops should be found growing under similar ecological conditions.

2. Enough coffee should be produced to make changes important to national totäls.

3. Different areas should represent a vide range of coffee productivity and alternative choices.

Some consideration was given to including the furrialba area in this study. Howerer, the diversification project in that area was just beginning to generate completel; new data when this work was undertaken.

Within the Linree areas belected, the local extersion agents 
selected farms they regarded as typical of size and ciass categories common in each paricular region. Data were collected by the agents listing the resources available and the resources used on each farm. A monthly breakdown of labor was supplied for each enterprise. In addition, budgets for several crops grown in the areas were made available from the Banco Nacional de Costa Rica and the Banco de crédito Agrícola de Cartago. The list of enterprises was further supplemented by crop cost study reports of the Ministerio de Agricul tura.

It is admitted that the farm case study approach cannot be statistically supported. However, by drawing upon the prior knowledge of the local agricuitural scientists, costs could be held to a fraction of the costs of working with a large random sample. Because it is likely to be the better farmers who contact and work with the extension agents, one may expect that the "typicai farms" of the extension agents may be above average. Nevertheless, this direction of bias need not be undesirabie since it is this group of farmers Who are most likely to first respond to economic incentives with either increased coffee output or diversification to alternative products.

Furthermore, the farms selected are in no way expected to be averaged to give a quantitative measure of po!icy response for more than each farm itself. The generalizations possible must be limited to direction and nature of cliange which may in turn iead to speculations concerning the response of the total coffee industry.

Although quantitative analysis is made at the farm level, extrapoldtion to larger areas must be with descriptive or qualitative anal. 
ysis. In this manner, associations can be made between poicy responses and various resource situations or enterprise possibilities. The uniformity, irregularity or lack of response can be noted for various policy alternatives. Thus the sample may indicate the kind of farm likely to support or oppose a particular political measure.

\section{Description of Farms Studied}

The farms selected for analysis are all located on the Pacific side of the Continental Divide. Farms were selected to represent the most common size-type categories found in the three areas.

\section{Falnares-San Ramón}

This area is made up of the intensive coffec-growing districts of the cantons of the same names. The Canton of Palnares, exccpt for the districts of Candelaria and Esquipulas, which are nor well suited for coffee, reported coffee on 94 percent of the farms and 37 percent of the land in 1963 (25).

The soils are fluvio-lacustrine groups cortaining diatomite (io, p. 3). Internal drainage may be a problem on level areas. A distinct dry season extends from December into April and Cood Hard Bean (2) type of coffee is grown at elevations belween 900 and 1,200 meters. Practically no rain Falls from Decembar to February $(6 t)$. In the districts of San Isidro and Sar, Ramón of the canton of san Ramón the Eond Hard Eean type of coffee is produced at alevations of 1,000 to 1,200 metars. In these districts, coffce utilizes 12 percent of the land and is found ch 83 percent of the farms. Tobacco, corn and beans are the major crops after coffes in the combined area. According to ha 1963 crosus, corfec was grown on 2,793 manzanas, 
corn on 417 manzanas, tobacco on 314 manzanas, beans on 226 manzanas, and sugarcane on 106 manzanas. Coffee output of the districts within the area made up over 3.6 percent of the national total and yields were roughly 37 percent above the national average in 1963 (25). Eight farms were used to cover a range of smal!, medium, and large units growing coffee alone and in combinations of coffee and tobacco. Farm 1 is a small coffee-tobacco unit in San Ramón. It is situated at an elevation of 1,080 meters on land described as moderately rough. The farm owner applied modern technology in the forms of fertilizer, insecticide, herbicides, and foliage fertilizer. The farm contains five manzanas with three manzanas planted to coffee and ¿wo manzanas planted to tobacco and corn. The labor force was made up of two hired male employees plus the family labor of a man, a boy, and two girls. Fixed expenses, including permanent labor, taxes, depreciation ard maintenance, and interest on the land investment totaled ${ }^{6}, 186$. Short-term operating capital including credit was estimated at $\xi^{4}, 400$.

Net farm income was calculated as gross returns less reported annual expenses and estimaied fixed costs including rent, taxes and hired permanent labor. Net farm income was estimated at $\$ 22,500$. The faim was chosen as an example of mixed cropping using modern technology and hand iabor.

Farm 2 in San Ramón is a small farm spacializing in coffee. Coffee was grown on all its seven manzanas. Labor was supplied by five male ard two female employees plus the family iabor of two men and two boys. The fixed expenses, ircluding permarent labor, totaled \$16,690. Operating capital and siedit available for variable casts 
totaled $\mathbf{s}^{4,000}$. Net farm income was estimated at $\$ 15,250$. This farm was chosen as an example of a specialized modern coffee producer. Farm 3 in San Ramón is a larger farm producing coffee, corn and tobacco. The farm covers fifty-six manzanas of which fifty manzanas were planted to coffee. The farm has a flue-cured tobacco contract for three manzanas. There were nine permanent employees and an administrator. The fixed expenses totaled $\$ 60,100$ and combined operating capital and credit totaled 671,100 . Net farm income was estimated at $\$ 34,130$. This farm was chosen as an example of a larger farm in the process of undergoing technological change.

Farm 4 is located in Palmares on nearly level land at an clevation of 980 meters. It is a middle-sized farm growing both coffee and tobacco. The farm reported fifteen manzanas planted to coffee and five manzanas in flue-cured tobacco. The farm hired two permanent employees and family labor consisted of three men, three girls, and two boys (part-time). Fixed expenses were calculaied a: $6 ! 4,840$. Annual operating expenses were $\$ 16,900$. The net farm income was estimated at $\$ 14,700$. This unit was selected as an example of a farm specializing in tobacco with low yielding coffee grown on other iand. Farm 5 is a medium-sized coffee farm in Palmares. The land is nearly level at an elevation of 1,020 meters. All ten nanzinas were planted to coffee. The farm unork was done by four men; two were hired and two were menbers of the owning family. The fixed costs were estimated at $\$ 10,732$ and the sum of the operating capital and shortterm credit amounted to $\$ 6,400$. The riet farm incone was estimated at $\$ 15,520$. This form was representative of a level of technology common!y used on farms slowiy adopting changes. 
Farm 6, also located in Palmares, is found on gently sloping land at 1,030 meters' clevation. It is a small farm with four manzanas of land of which 3.75 manzanas were planted to coffee. The farm hired four permanent employees. It had no administrator nor family workers. The $\$ 12,480$ estimate of fixed expenses included very high permanent labor costs. There were $\$ 4,000$ available for annual expenses, including credit and operating capital. The farm operated at a loss estimated at $\$ 6,760$. This farm was chosen as an example of a small property owned by an absentee owner.

Farm 7 is located on moderately rugged land at 1,025 meters' elevation in Pa!nares. It is a small farm of six manzanas with three manzanas of coffee and one manzana of sun-cured tobacco reported. Pasture was grown on two manzanas. The farm employed one man and exira work was supplied by two members of the owning family in times of emergency. Fixed expenses were calculated at $\$ 6,000$ and $\$ 4,300$ were reportedly available for variable expenditures. The estimated net returns were $\$ 3,345$. This unit was selected to represeni a small farm with mixed production.

Farm 8 is also located on moderately rugged land in Palmares. It covers two manzanas of land of which one manzana was planted to coffee and one-hali manzana is planted to sun-cured tobacco. One permenent employee was hired and two mer. and two boys (part.otime) of the owning family worked on the farm. Fixed exponses more estimated at $\xi^{2}, 882$. Operating capital and short-mtern credit was $1 \mathrm{imited}$ to 8900. The coffee planted was not yet in production but anticipated yields gave experted annual returns of 62,653 . This farm was selacted as an sxample of a very small farm using multiple cropping. 
Alajuela

The Alajue!a area is located around the town of the same name. The land is made up of rolling hills with occasional areas of nearly level topography. In general, the soil is rich, being influenced by reoccurring ash fall, which results in andosols with high organic matter content, although considerable variation is found in both topsoils and subsoils (71, p. 26). The elevation ranges between 700 and 1,100 meters. The districts of Alajuela, San José and Desamparados were used to represent the region in the 1963 census data. I In 1963 , average coffee yields for these three Alajuela districts were 27 percent above the national average and coffee occupied 1,980 manzanas. In the same year, there were 82 manzanas of pineapples, 137 manzanas of corn, 186 manzanas of beans, 17 manzanas of tomatoes, and 14 manzanas of cassava reported (25). Coffee was reported on 76 percent of the farms and occupied 26 percent of the land area in 1963.

Although rains may occur throughout the year, a diy season extends from December into April (64). The coffee produced is the Hard Bean type (2). The representative districts selected from the 1963 census produced 2.43 percent of the national output of coffee. However, the ecological conditions of these districts extend into parts of adjacent districts.

Four farms were selected for study from this region. Farm 9 is located near ar elevation of 1,100 meters on genily rolling land in Alajuela. It is a large family farm with 40 manzanas, all in cofree.

lPolitical subdivisions do not coincide well with ecological areas; triverore, the consus data must be interpreted cautiously. 
Labor was supplied with ten permanent employees and the farnily labor of two men and two boys (part-time). The fixed expenses were estimated at $\$ 48,575$ and short-run credit and operating capital totaled $\$ 22,200$. The estimated net returns were 690,000 . This unit was chosen to represent large coffee farms with both good coffee and horticultural possibilities.

Farm 10 is located on rolling land above 1,000 meters. All of its 15 manzanas were planted to coffee. Labor was supplied by five permanent employees and two men and a boy of the family. The fixed expenses were estimated at $\$ 21,875$. The operating capital and annual credit totaled $\$ 15,750$. Estimated net returns were $\$ 17,160$ but young plants raised expected future returns to $\$ 30,000$. This färm was selected to represent the medium-sized specialized farm with good al ternatives.

Farm il covers 10.5 manzanas of nearly level land at 700 meters elevation in Alajuela. Coffee was planted on five manzanas. Fineappie was grown on the remaining land. The farm utilized the labor of cne tired employee and one man, two boys, one woman, and one girl of the family iabor force. The fixed expenses were estimated at 49,670. A sum of 68,850 was available for annual operaing expenses. Farm income was estimated at $\$ 42,980$. The horticultural crop was sold into the high-priced fresh fruit market. If the famer received processing prices for the pineapple, farm income would fall to $\$ 9,330$. Pineappies would be discontinued since raturns at processing prices would fall to about one-half of the cost of production. This fam was chosen to represent the middie-sized producei of coffee and fresh market fruit. 
Farm 12 lies on rolling land at 1,100 meters near Alajuela. The farm contains 5.5 manzanas of 1 and of which 2.5 manzanas are planted to coffece and the remainder is planted to sugarcane. Five men made up the farm's work force; two were hired and three were members of the owning family. The fixed expenses were estimated at $\$ 7,905$ and credit and capital for annual expenses summed to $\$ 1,115$. The annual net return to the reported sugar and coffee enterprises was estimated to be $\xi^{6,122}$. This farm was chosen to represent small mixed-crop farms.

\section{Acosta}

This area is around San Ignacio de Acosta. This zone lies to the south of the Central Valley on rugged, eroded latosols of an intermountain valley. The coffee of San Ignacio is mostly grown at elevations between 900 and 1,200 meters. In the 1963 census, 38 percent of the farms reported growing coffee on 15 percent of the area. In 1963, coffee was reported on 1,098 manzanas which greatly surpassed 317 manzanas of beans, 174 manzanas of corn, 65 manzanas of sugarcane, and 24 manzanas of cassava (25). Most of the land was in pasture or forest.

The dry season is less pronounced in Acosta than in Alajuela. Only January averaged less than $50 \mathrm{~mm}$ of rainfall during the period from 1961 to $1955(6 /)$. The heavier and more uniform iainfall brings about a slight rediction in quality from that which the elcvation of the area would suggest. Quality falls into the liard Bean category (2). Leaching and erosion have reduced the natural feritity of the area.

Traditional practices have fersisted in the Acosta area. Tha 
district coffee yields were 64 percent of the national average. San Ignacio produces only 0.67 percent of the Costa Rican coffee; however, conditions are similar in other districts along and beyond the southern rim of the Central Valley. The area was included in the study to represent a poorer coffee-growing region which fits a definition of "marginal land" based on low output per unit of land and labor (27). Farm 13 is a large coffee producer in Acosta. The farm covers 101.5 manzanas of rugged land averaging 1,100 meters elevation. Coffee occupied 90 manzanas and 1.5 manzanas were planted to oranges. The remaining ten manzanas were used to produce a joint crop of corn and beans. Labor was supplied by four male family members and thirteen hired men and one hired woman. Fixed costs were estimated at $\$ 47,496$ and $\$ 51,500$ were available for annual expenses. The net farm income was estimated at $\$ 66,878$. This farm was chosen to represent large farms with poor soils.

Farm 14 is a medium-sized unit in Acosta located on rough land at 900 meters elevation. The size is 16 manzanas of which 7 manzanas were planted to coffee. There were 4 manzanas of oranges and 5 manzanas of corn and beans reported. The farm had 3 aduit male family workers. The fixed expenses are $\$ 1,184$ and $\$ 5,945$ were availabie for anrual operating expenses. The estimated net returns were $11,4: 46$ on this middle-sized farm with mixed cropping.

Farm 15 is a small Acosta unit on neariy level ground at !, 100 meters. It had 2 manzanas planted to coffee with interplanted orange trees supplementing farm income. The farm fanily supplied the labor of one man and three women. The fixed costs were estimated at $\mathbf{r}^{4} \mathbf{2 4}$. Credit and operating capital totaled $\$ 225$ for shorturun expenses. 
The farm reported a net income of $\xi 1,003$. However, the costs included an abnormally high number of new plants which suggested that an investment was being made. The net income estimate was therefore adjusted to $\& 1,403$.

Farm 16 is a second small farm in Acosta. The farm contains 6.5 manzanas of which 1.5 are planted to coffee with scattered orange trees. The labor was supplied by one man and one woman of the owning family and also a hired man and a hired woman. The fixed expenses totaled ${ }_{2,988}$ and $\$ 675$ were available for variable costs. The farm income was estimated at $\$ 1,339$. This farm was considered typical of the small, mixed-crop farms of the area.

\section{The Linear Programming Model}

It would be presumptuous to claim that a study using one year's deta and manv imported or estimated production cnefficients would be sufficiently accurate to permit the calculation of optimal management plans to the five decimal places provided by the University of Florida computer, However, the lack of a high degree of accuracy of data should in no way be a deterrent to the use of the computer to solve problems of a practical nature.

Linear programing is now widely usid as a farm management analysis technique. However, in this particular study the emphasis is put upon policy rather than production analysis. The input and output coefficients may or may not represent lue possibilities for the farm groups studied. However, they do reprosent the expected possibilities open to those farmers based upon limited experimental data, reported experience: and the opinicns of the extension agents who advise them. Therefore, the mocel atiempls to predict how it would pay the farm 
decision makers to react to a series of policy measures given certain expected cost-output reiationships for coffee and various alternatives. The results were expected to provide implications with respect to actions that farmers would be likely to take in response to program changes.

The linear programming model is a computational method used to minimize or maximize a linear function given a series of linear inaqualities as restraints (33, p. 7). Net returns or profits were maximized for each farm studied. The matrix in each application of the model was comprised of the following sub-matrices: A production sub-matrix was made up of input-output coefficients for the mionthly land and labor requirements, capital requirement, rotation requirements and coffee land requirements for the various crop production activities. Costs were included as negative entries into the profit row and yields were included as negative entries in transfer rows. A selling sub-matrix consisted of price coefficients in the profit row and unitary entries in the product transfer rows. A transfer sub-matrix was comprised of coefficients of columns repiesenting labor purchasirig, coffee planting, coffee destruction, borrowing, long-term credit and fixed cost transfer.

The matrix included input coefficients for the monthly land and labor requirements of the various enterprises. Additional restraints included operating capital, rotational limitations, and coffee piantings. Production coefficients were entered in transfer rows to be soid via seling encerprises. Monthly labor purchesing was $1 \mathrm{imited}$ to a 2 to 1 ratio of adult male fabor which allowed two temporary workers to be hired for each permanert employee as a lavor 
supervision restraint. Planting and destroying coffee trees were entered with cost and investment coefficients. New investments were not limited but were given a cost through a borrowing column. Coffee harvesting was handled ty using both contract and family labor harvesting. A special family labor restriction was used during the harvest months. Excess labor was allowed to be sold during the coffee harvest but not at other times.

Parametric programming was used to estimate the effect on optimization when changes in policy and in production levels occurred. Coffee yields were programmed downward 50 percent. Ccffee price was reduced $\$ 100.00$ and printouts were made at $\$ 5.00$ intervals. A continued annual payment for coffee removal was considered. Operating capital was reduced 70 percent. A special credit row allowed the operating capital requirements of expandable alternative crops to be reduced. Credit was increased. A two-price system allowed differentiated coffee prices to reflect returns to coffee sold in traditional and in new markets. Prices and yields of certain alternatives were moved upward and downward. All new crops vere exoluded by downward price manipulation. Family labor and hired labor were permitted to be shifted off the farm. Lastly, higher yielding coffee aiternatives were allowed to enter wich additional investments.

The farms selected were analyzed using linear programing to maximize profits for a one-year period. Anruai crops were considered using land, labor, and operating capital coefficients taker directly from enterprise budyets.

Enterprises requiling new long-term investments were considered using mantonance costs and return ostimates for an annual period 
after commercial production would become statilized. Establishment costs of permanent crops were calculated with opportunity costs included as part of the investment to be considered using interest charges. Thus, loss of income during the establishment period was estimated and added to material and labor costs making up the investment calculation. The cost of making this investment was computed using a low interest rate of 6 percent which assumed special longterm credit subsidies for permanent crops.

The coefficients for intermediate length enterprises were calculated by summing the budget entries for the years of duration of the crop. Thus the unit used was a "planting unit" or that area planted each year and assumed an averaging of resource use over time. This admittedly limited the strategy of cropping plans to be considered, but this simplification greatly reduced costs of analysis while coinciding with the generally followed procedure of "evening out" inputs over time.

Presently established iong-term coffee enterprises were entered into the matrix without calculating investment costs. Additional plantings were allowed but were associated wi th long-term interest charges on the investment.

Depreciation of the investmeni was not considered for the permanent crops. If the annua! expected returns surpassed returns of other alternatives after interest costs were paid on the investment, then it was assumed that the investment was an additior: to not worth which offset the original expenditure.

To further clarify the model, the mechanics of the less conventionel manipustions are given in more dotail. Operating capital was taken as a shortutern credit restraint. All annual cosis except in- 
terest, transportation, and contract harvesting vere used to determine the requirement for operating capital of each enterprise. Reported expenditures were taken as the row constraint for each farm.

Rotational restraints for annual crops were handled in the following manner: Total farm land was used as the constraint on the right-hand side. Each manzana of permanent crop used one unit of the rotational limitation. Then the crops requiring rotation received a coefficient equal to the minimum number of years during which only one crop would be permitted. A coefficient of one allowed an average of no more than one crop of beans per year. A coefficient of five allowed only one crop of cucurbits in five years. This restraining row cannot be used to set up the sequence of a rotation but does insure that the optimal solution does not include a degree of crop Epecialization contrary to required pest control practices.

Coffee plantings were used in three different constraining rows. To insure that new coffee land was charged the cost of planting coffee, maximum coffee land was set equal to or less than reported coffee land plus land newly planted to coffee. To account for tree removal costs of shifting land from coffee to other uses, another row set optimal coffee land equal to or greater than reportad coffee land plus the land from which coffee was removed. A third constraining row set coffee removal at no more than reported coffee land to block irregular possibilities as payments were made for coffee removal in parametric operations.

Coffee harvesting requirements wore handed in the following manner: Coffee seiling enterprises vere given a coffee harvesting requirement. An option was given for haryesting, aliowing either 
contracted labor or family labor to be used. The first means of harvest used a cost of $\$ 40.00$ per fanega. The utilization of family labor used monthly labor resources and family labor resources at a level of four or five hours per fanega each month during the harvest period.

Parametric programming was used to anticipate the effect of various policy manipulations and to test the stability of the optimal plan in the face of certain price and yield changes.

The use of selling enterprises made the programming of price changes straightforward. A change row in the matrix contained coefficients of change. Programming cards determined the magnitude of change and the frequency of printout. Thus, the solution of the program was continually re-evaluated as additions or substractions were made to coefficients in the objective function. $c_{j}{ }^{\prime}=c_{j}+x_{j}$ (N) where $C_{j}^{\prime}$ is the new price, $C_{j}$ is the old price, $X_{j}$ is the change row entry and $N$ is the parametric multipiier ranging from 0 to a given maximum. Prime decline used a regative $X_{j}$ value.

Yield changes were programmed using "PARAROW" parametric additions or subtractions. The solution of the program was re-evaluated as a changing multiple of change row coefficicnts was added to the coefficients of a resignated transfer row. $P_{j}{ }^{\prime}=P_{j}+x_{j}$ (M) where $P_{j}$ ' is the changed yield, $P_{j}$ is the old yield, $x_{j}$ is the change row coefficient and $i v$ is the parameiric multiflier. Proportional changes of several enterprises producing the same produrt was allowed by setting $X_{j}^{\prime} s=P_{j} s^{\prime}$.

The effect of special credit faci:iziss to finance the production of the non-traditional cash crops was handled by a parametric reduction of the use of normal operating capitei of the favored enterprises. 
This assumes a selective policy of credit expansion for crop diversification. The "PARAROW" operation was mechanically like the yield change procedure. $k_{j}{ }^{\prime}=k_{j}+x_{j}(N)$ where $k_{j}{ }^{\prime}$ is the new credit coefficient, $k_{j}$ is the old credit coefficient, $x_{j}$ is the exchange row coefficient and $N$ is the parametric multiplier. With $\left(X_{j}\right)$ equal to $K_{j}$ and $N$ equal to one, $K_{j}{ }^{\prime}$ equals zero and the credit needs of favored crops are all supplied by the new unrestricted source of credit.

The effects of a reduction of credit were analyzed by using "PARARHS" procedures. The parametric programming of the credit constraint, a right-hand side value, used an exchange column coefficient set equal to the credit constraint. The parametric multiplier ranged from 0 to .70 . This assumed 30 percent farm supplied operating capital as the iower limit of practical credit reduction. $k_{r}{ }^{\prime}=k_{r}+$ $\left(-x_{1}\right) N$ where $K_{r}{ }^{\prime}$ is the modified credit constraint, $K_{r}$ is the old credit constraint and $-x_{r}$ is the coefficient of the exchange column. In a similar mancer, an increase in credit was programned with available credit being increased up to $\dot{2}, 000$ per manzana.

A programming procedure was devised to evaluate the effect of differentiating firm prices between sales into the new and into the craditiona! market. Since the new market price was roughly 25 percent below the traditional market price and the new market took roughly 25 percent of total output, the differentiated new markat price was set at 80 percent of the current farm price and the traditional market price set at $1062 / 3$ porcent of the current farm price. The coefficient of the new maket coffee selling anterpise was not changed by the paranetric addilions. The traditional market seliing 
enterprise was given a functional coefficient of zero. The exchange row included coefficients for both the traditional market selling enterprise and the current coffee selling enterprise. The former was the estimated price that coffee would receive were it sold only in the traditional market. The latter was a negative price coefficient devised to exclude the average or current coffee selling activity as the sale via the higher priced selling enterprise was permitted.

Table 1. Partial matrix of coffee selling activities

\begin{tabular}{|c|c|c|c|}
\hline & $\begin{array}{c}\text { Averaged } \\
\text { market }\end{array}$ & $\begin{array}{l}\text { New } \\
\text { market }\end{array}$ & $\begin{array}{c}\text { Traditional } \\
\text { market }\end{array}$ \\
\hline Profit & 200 & 1.60 & 0 \\
\hline Coffee transfer row & 1 & 1 & 1 \\
\hline Limit to traditional market & 0 & 0 & 1 \\
\hline Change row & -200 & 0 & $2.131 / 3$ \\
\hline
\end{tabular}

By referring to Table 1 , it may be seen that parametric changes will first block selling in the averaged market and then permit selling in the traditionai market. Sales in the traditional coffee market were limited to 75 percent of the reported output of each farm. The single printout of the solution was calied when the values of the change row were added to the functional. The price coefficient for the averaged market was reduced to zero. That of the new maiket was unchariged and that of the traditional market was increased to $1062 / 3$ percent of the averaged price. In this manner the marginal leturn for aditional coffee on each form was set equal to ine 
corresponding morginal returns to the country and each farm would receive a price based upon new market returns for production in excess of the quota. In this manner, the benefits of higher prices in the traditional markets could be passed on to the producers without increasing incentives for overproduction.

The payment for the removal of coffee trees was programmed as a continuing payment made after the removal of coffee trees. An activity for coffee destruction was given an annual cost to force the payoff for coffee removal to be made in five years. Subsidizing coffee tree removal was programmed with a change row entry in the coffee tree destruction column. Payments from 0 to $\xi 1,800$ per manzana were covered with printouts on 2200 intervals. The calculation of payments equal to 20 percent of coffee's gross returns per manzana was made using interpolation where there was no change in resource use between the 20 percent payment and one of the printed outputs. When the straight-line interpolation could not be made, the problem was re-run with output demanded where the payment was equal to 20 percent of the gross returns to coffee.

Algebraically, $C_{d}{ }^{\prime}=C_{d}+x_{d}(N)$; where, $C_{d}{ }^{\prime}$ is the return for destroying one manzana of coffee, $C_{d}$ is the cost of destroying one manzana of coffee, $x_{d}$ is the unitary exchange row entry and $N$ is the parametric multiplier which represents varying levels of subsidy payment. In adition, the exchange row contained a large negative entry in the coffee planting column to block new roffee plastings if payments were made for coffee remuva!.

The effect of outside employrant on family income was studied using parametric changes of the objective function. In an original 
matrix, a column represented the reduction in monthly labor supply as a man left the farm for other employment. Additional entries represented the effect on the monthly hiring of temporary labor and monthly family labor for coffee harvesting. Also, a constrained row restricted movement to adult male farnily members. Since this use of resources received no returns it would not come into the initial optimal solution. Then returns were entered with parametric changes to record the response of income and output as outside opportunities increased to the level established by minimum legal wage laws. Therefore, $c_{w}=x_{w}$ (iv); where, $c_{w}$ equals outside wage returns per man, $x_{w}$ equals the exchange row entry of the legal minimum wage, and $N$ equals the parametric multiplier ranging from zero to one.

The effect of moving permanent employees to other jobs was handled in a similar manner. The only differences were that the exchange row coefficient was smaller, reflecting the part of the calculated permanent labor cosis that are not cash expenditures, and entries for family coffee harvesting were not applicable since permanent employees are paid by the fanega for harvesting coffee. Movement was restricted to adult male employees.

Parametric changes in the interest rate for long-term investments were progranmed with the sanie procedure as price changes. The cost of borrowing was increased from 6 to 20 percent of the investment. An investment row requires that money be supplied to neet $i$ rivestment requirements via a borrowing activity. An exthange row entry is multiplied by an increasing number so that $1^{\prime}=1+x_{i}(N)$; where, $i^{\prime}$ equals the new interest rate, 1 equals the old interest rate, $x_{i}$ equals the change row element in the borrowing column and in equals 
the parametric multiplier. This procedure was used to evaluate the effect of interest rate changes on the stability of resource use.

The fact that economic development is a lorig-term phenomenon may stimulate objections to the use of a model maximizing returns to a single year. With more work and more computer expenditures, it would have been possible to build a growth model maximizing returns over a period of five, ten, or even twenty years. Such a study could quite dramatically illustrate the gains to be derived from more investment capital, cheaper interest rates, longer term loans and the cumilative effects of modern inputs.

However, there is a danger in trying to extract too much information from limited data. The data were collected with interviews in a single year. The effects of one crop on surcessive crops are not yet known. Any errors in reporting, interpretating, and evaluating the data will be multiplied not only by the simple coefficient of time but also by complex coefficients reflecting the fact that each year's output becomes part of the next year's inputs.

To be accurate, the long-term growth model also requires correct predictions of the interest rates and future credit availability. fn even more difficult prediction centers on technology. Will yields remain constant? Will they remain proportiona? if they change? Wili some resources become outdated? If changes occlir, when will they occur? Wil! technological changes be accompanied by changes in factor prices and product prices? The common conomic practice is to avoid these questions by assuming constant technology. This excludes a chief source of growth from the growth model. 
Those crops of greater economic importance are likely to receive the greater agronomic research. This means that specialization or monoculture is likely to be encouraged by technological change. Also, larger commercial farms can be expected to change faster than small, near subsistence units. Thus, while it is possible to predict the direction or tendencies of certain differences in crop technology, the magnitude of those differences will be difficult to estimate.

These statements should not be taken as a general argument against long-term planning or programming. Such an attack on problems is worthwhile despite the inherent difficulties. However, with the data and prior knowledge avai lable, it was decided that more practical information could be gleaned from a singie-year model having more a) ternatives.

\section{The Enterprises and Restraints}

One of the basic assumptions of the linear programming model is that a finite number of alternatives and resource restrictions exist. The number of combinations of factors must be limited but the degree of limitation is arbitrary and depends upon the use that is to be made of the model.

In this study, the cbjectives were to compare coffee with alternative enterprises. A number of different processes or methods of growing coffee and different processes for core of the aiternative enterprises were considered because, with differant farn resources and parametric changes, ore particular technology was nct obvicusly superior to the others. Also, an averaging of inputs and yields is not particularly meaningful since distiricty different technologies 
related to differences in yields are known to exist. In the decision as to the number of processes for an enterprise the availability and the accuracy of the data were taken into account. Activities were chosen to represent different intensities of the use of labor and operating capital as well as different levels of modernization. Activities found on the poorer farms were included in the better farms' alternatives. However, the activities requiring high levels of technical skills were blocked for the poorer farms in the initial solution and were considered only in special parametric procedures.

The activities were coded from budget data supplied by the extension agents and also from the budgets of the agricultural credit reports of the Banco Nacional de Costa Rica and the Banco de Crédito Agrícola de Cartago and the Ministerio de Agricultura y Ganadería. These soulces supplied data concerning material inputs, labor hours and timing of various work operations and expected yields of selected enterprises in particular areas. In addition, activities ivere synthesized from foreign input-output data which were modified to anticipate costa ficar, conditions by adapting labcr requirements for particular work operations froin currently grown crops. Research studies of the Universidad de Costa Rica were used to supply data for certain horticultural activities.

Activities based cn foreign or smail pesearch plor data were entered with what was believed to be "conservalive" yield estimetes. The results of plot trial yields were estimated by using the lovest variety yield which was rot significant? different dat à 5 percent ievel! from the highest varicty yidd.

One problem that arsso was the fitting of the labor requirements within the monthly labor conninits. In most cases the farm enter- 
prise reports placed the labor for each work operation within a given month; however, in a few instances the reports spread work over a two- or three-month period. Overlapping time periods would have made the computations much more costly. Instead, two processes were sometimes used for timing the input use of labor, and the labor uses in other cases were arbitrarily placed in months so as not to compete wi th coffee harvesting.

The use of operating capital and short-term credit was handled together to avoid antagonizing the cooperating farmers. The extension agents felt that loan information was personal and requested that this section be deleted from she original forms. Therefore, total short-term expenditures were used as the right-hand-side constraint for the operating capital and credit rov for each farm. This assumed that the farmers were using as much bank credit as they could get. A.s a result, the credit situation is oversimplified in the model, but the complications of overborrowing for consumptici or non-agricultural uses are thus avoided. These complications would be difficult to identify using interviews since some common practices are of questionable legality.

For the Palmares and Sari Ramón areas, the programing matrix was made up of 81 rows and 94 columns. The rows inciuded 12 for monthly labor use, 12 for monthly land use, 12 for temparary monthly labor use, 4 for monthly family harvesting labor, 1 for opcraing capital and credit use, 3 for tobacco contract, 1 for investment, 1 for fixed expenses transfer, 14 for product transfer, 3 for coffee land, I for coffee harvesting, 1 foi corn shelling, I for land transfer, 1 limiting row for traditional coffee markei sales, 2 crop 
rotation requirement rows, 2 labor movement rows, 9 exchange rows for parametric chenges, and l profit row.

The columns included 10 coffee growing activities, 9 tobacco growing activities, 8 corn growing activities, 4 joint corn ard bean growing activities, 4 bean growing activities, 2 sesame growing activities, 2 castorbean growing activities, 5 dairy activities, 2 beef activities, 1 peanut growing activity, 2 buckwheat groiving activities, I chickpea growing activity, 1 pigeon pea growing activity, 1 mixed crop producing activity, 1 annual to monthly land use transfer activity, 3 coffee selling activities, 3 tobacco selling activities, 8 grain selling activities, l calf selling activity, l milk selling activity, 4 monthly labor selling activities, 2 yearly labor selling activities, 12 temporary labor hiring activities, l borrowing activity, I coffee planting activity, l coffec-destroving activity and one fixed cost transfer column. A listing of the row entries of each of the activitiss programmed is given in the Appendix.

only farms 1 and 2 were programmed to allow the use of all the activities coded for the area. Farms 5, 6, 7 and 8 were not using the same high levei of tectinology as that found on farms 1 and 2. The tivo most productive coffee-growing activities were blocked by removing the coffee production transfer card. A changye row entry was substituted and an investment entry added so that a paremetric pro. cedure would evaluate the acceptability of the change if education were to permit its uccurrence.

Farms 3 and 4 were below-average coffec producers. They were permitted to use only the last profilahle coffecmgrowing activities of the aron. Again a paromen ic procodure allowed higher production, 
assuming that education and long-term investment could make the higher yields possible.

In the Alajuela area, the matrix was composed of 94 rows and 87 colurins. The rows included 12 for monthly labor, 12 for monthly land, 12 for temporary labor, 4 for monthly family labor for coffee harvesting, I for investment, I for operating capital, 1 for coffee harvest, 19 for product transfers, 4 for rotation limits, 1 for yearly land, 1 for fixed expenditures, 3 for coffee land, 2 for off-farm labor movement supply, I for limiting sales in the traditional coffee market, 12 for changes in parametric modifications and 1 for profit. The columns included 9 coffee growing activities, 1 lime growing activity, 1 orenge growing activity, 3 corn growing activities, 2 corn-bean growing activities, 3 bean growing activities, 1 pineapple growing activity, i strawberry growing activity, 6 sugarcane growing activities, 3 cassava growing activities, 2 cucumber growing activities, 2 sweetpotato growing activities, 2 tomato growing activities, 2 sweet pepper growing activities, I peanut growing activity, 1 chickpea growing activity, 1 buckwheat growing activity, 1 pigeon pea growing activity, 1 dairying activity, 3 coffee selling activities, 16 alternative product seliing alternatives, 2 coffee harvesting activities, 2 all-year labor selling activities, 4 monthly labor selling activities: i? monthly labor hiring activities, 1 fixed cost transfer column, I land transfer coimm, I coffee plantirg activity, I coffee destroying activity, and 1 borrowing activity for long-tem credit.

With the exception of farm 9, the two highest-yieiding coffee activities were blocked for the original solutions and allowed to 
enter with parametric changes. Lime and strawberry selling activities reflected prices estimated for processing use. These prices were \$13.00 per quintal for 1 imes and $\$ 1.00$ per pound for strawberries. These prices were conservative estimations for the Central American Common Market and were programmed both upward and downward to fit conditions of the fresh market and world market, respectively. Actually, average current prices are much higher in the local fresh fruit markets; however, these high prices would be unstable in the face of ary sizabie change in quantity.

Tomatoes and sweet peppers were also priced for processing use. The price used for sweet peppers was lower than the quoted contracting price because pepper contracts were tied to tomato contracts.

Cassava, cucumbers, and sweetpotatoes were priced at the reported market lows of the two years prior to the survey. Parametric changes lowered vegetable prices to levels competitive in the world market.

While substantial changes in technology would be required if the fruit and vegetable activities repiaced coffee, these changes were permitted in the model because the extension and research facilities seem capable in the zone. The experiment station of the Universidad de Costa Rica is located in the zone and specializes in liorticultural crops. It is easier to seil new ideas when they have been tested under local conditions and the results are being apolied by the agronomists on their private commeroial farms.

In the study of the Acosta area. the matrix contained 65 rows and 60 columns. The rows included 12 for monthly labor, 12 for monthly temporary iabor supply, I for investmens, l for operating cepita!, 3 coffee land limiting rows, 5 for monthly family labor for 
harvesting, I fixed expenditure transfer row, I row limiting coffee sales to the traditional markets, 1 coffee harvesting row, 1 yearly land supply row, 9 for product transfers, 2 for off-farm labor movement and 1 profit row.

The columns included 7 coffee growing activities, 2 joint coffeeorange growing activities, 3 joint corn-bean growing activities, 1 blackberry growing activity, 2 orange growing activities, 2 beef producing activities, 5 dairy activities, 1 lime growing activity, 3 coffee selling enterprises, 8 selling enterprises for other farm products, 2 coffee harvesting activities, 5 monthly labor selling activities, 12 monthly labor hiring activities, 1 fixed cost transfer column, 2 yearly labor selling activities, 1 coffee planting activity, 1 coffee destroying activity, and 1 borrowing activity for long-term credit.

Since the growing periods for all the crop activities programmed for Acosta overlapped, land was programimed as a single resource instead of being divicied into monthly intervals of use.

Ecologically, Acosta is poorly suited to annual cropping. Corn and beans were included because they are traditionally grown. Other annuals were exclided from the area's model in order to conform with conservation equisities.

The coffee yields in Acosta are less than the yields of the other two areas. Focrer technology may have resulted fron relative isolation in past years. However, lower fertility is chiefly responsible for lower yieids. Two higher-yieiding coffee groning activities were blocked in the initial solution but were allowed to enter in a parametric procedure representing technologica! change.

Two price ieve!s were used for fruit selling in Acosta since 
selling opportunities could be greatly affected by the nearness to market outlets. Fisks and transportation costs would be reduced if a processing plant were built in the area. Prices were discounted 30 percent for 1 imes, 25 percent for oranges and 50 percent for blackberries when local outlets were not anticipated.

In calculating production costs for the production activities, short-run interest charges of 8 percent were added to the costs of materials.

\section{The Sources of the Budgets}

It was necessary to use agronomic data from several different sources to construct the matrix of input and output data used in the study. Farm resource information and input-output data were provided by the extersion agents in each area analyzed. The extension agents collected data from the farms they considered typical of the various farm siae and type classifications found in their particular region. Most of the budgets for coffee, corn, beans and sugarcane were provided by the cooperating exiension agents. Thase were supplemented by data provided by the Banco ivacional de Costa Rica (18) and the Banco de Crédito Agrícola de carrago (53).

San Ramón and Palmares farms were grouped together in the analysis. !ng. Efraín Abarca coilected data from San Ramón includirg budgets used in the most productive coffee activities yielding 27.6 , 25.7 and 20.0 fanegas por manzana. 199. Danilo Zamora collected data froni falmares farms which reported coffec yields of $19.0,15.0$, and 5.3 tanegas per manzana. The best yields included herbicide use, three applications of fertilizers, insecticide use and moderate pruning and vecdirig labor. Somm plactices included the use of 
fertilizer and insecticides and gave yields above the national average. Coffee activities using traditional methods were programmed from data of the Banco Central de Costa Rica (7). Moderately heavy labor with few purctased inputs produced a yield of 9.0 fanegas per manzana. An activity of semi-abandoned coffee was based upon conversations with Ing. Hugo Castro. Yields up to 4.0 fanegas per manzana were obtainable without purchased inputs other than sacks and without labor except harvesting and enough weed cutting to allow the pickers to walk. The extension agents' farm budgets also included corn and bean activities. Common corn yieids ranged from 13.3 to 40.0 quintales per manzana. Higher-yielding activities were programmed from data furnished by 1 ng. Walter Vilialobos from 4.0 S Club plots at Santa Ana. Yields were modified to 70.0 quintales per manzana maximum to correspond with the reportedly poorer growing conditions. The moderate use of fertilizer and insecticide, as reported in the worksheets of the Banco Nacional, yields 48.0 quintales (18).

Bean activities were based on budgets from the following sources. Modern technology yielded 18 and 20 quintales per manzana according to budgets derived from a ministry of agriculture publication (51). The Banco Nacional supplied budgets of low-yielding bean crops from broadcast planting that yielded only 4.2 quintales per manzana and traditiona! methods that yielded 9.6 qui!ltales per manzana (18). Joint corn and bean production activities were programned ailowing combinations of the average and poorer yislding corn and bean activities comonly growin together.

Tobacco growing activities were programmes from budgets of the Junta de DeFensa dei Tobaco (36) and the Banco ivacional (18). Yields 
ranged from 18 to 20 quintales per manzana but the budgets from the Banco Nacional used lower levels of inputs.

Sesame was programmed using a budget of traditional methods supplied in Ospino's work (58). A budget of modern practices for growing sesame were synthesized using data from the United States $(21,38,39)$. An estimate of yield expectations was placed at 20 quintales per manzana despite reported yields up to 35 quintales per manzana.

The castorbean production activities were based on synthesized budgets based upon foreign agronomic data $(20,72)$. Yields were estimated at 34 quintales per manzana.

The traditional activities for producing dairy were based upon reported budgets from Atenas by 1 ng. Adrian Prado. More intensive dairy production activities were based on budgets from Heredia supplied by Ing. Carlos Norza. Production ranged from 400 to 1,200 bottles of milk fer manzana with extensive land use and from 1,000 to 2,000 bottles with more intensive operations.

An extensive beef calf producing activity and a moderately intensive beef producing activity were budgeted by Ing. Ramón Castro in San Carlos with one cow per 5.0 manzanas in the first case and one cow per 1.5 manzanas in the sccond. Much higher range productivity was reported in studies made in Puerto Rico (14). However, the cost of production. vould not be covered by Costa Rican prices.

Pigeon paa production activities were based on budgets synthes zed from agronomic data chiefly from Hawai $(31,40)$ medified by Costa Rican recommendations (50). Reported yields reached 20 quintales per mãnzana. 
Buckwheat was included as a catch crop. Yields were programmed at 8 and 20 quintales deperding upon the time of planting. Reported production in Mexico (70) and Ceylon (4) showed that this crop could be grown in tropical countries.

A peanut production activity was included although part of the soils may not be well adapted. Yield was programmed at 20 quintales per manzana as Banco Nacional data from Alajuela were used to synthesize a budget.

Chickpeas were included as a dry season catch crop. Cultivation is similar to beans ( 47 ) and the yield expectations are 5 quintales per manzana.

A mixed crop enterprise was synthesized from other budgets combining corn and legumes with high labor inputs.

Coffee price was determined by an unweighted average of the prices paid by the beneficios in Pa!mares in the 1966-67 crop year. Corn and bean prices were reported by the extension agents. Peanut and sesame prices were included in the credit worksheets of the Banco Nacional (18). Castorbean price was computed from the world dollar price. Buckwheat was priced arbitrarily low to reflect probably limited acceptance as a feed grain. The chickpea and pigeon pea prices reflected estimated wholesaie prices based upon retail prices in sin josé as compared with beans.

In the study of the Alajuela farms, budget data on coffee production were supplied by Ing. Guijlermo Montenegro. Yields ranged from 25 fanegas per manzana on the best farn to 16 fanegas per manzana on the poorest farm. The maximu yield fermited without tochnological change modifieations was 20 fanegas per nalizana except on farm 9 which had already adopted modern produrtion techingues. Traditional and 
semi-abandoned coffee production activities were included with the same coefficients used in the Palmares-San Ramón matrix.

Lime production was programmed with input-output data synthesized from Florida sources (42). Yields were 400 quintales per manzana. This approximates a U.S. yield of 462 bushels per acre. costs of establishment used $U$. S. costs but annual labor costs were modified by data from Costa Rican orange production budgats.

The orange production activity was programmed from data of modern orange production in Guatemala (49) and Florida (28). Yields vary with the age of the trees but an estimated yield of a mature grove was taken at 1,020 cien (hundred fruit). This approximates 300 boxes of fruit per acre.

Tomato production activities covered common and modern producing techniques. The common yield of 11.25 tons per manzana was reported in a budget worksheet of the Banco Nacional (18). Experimental results of agronomic trials show yields that surpass 20 tons per manzana (26).

Corn production activities were based upon 4-S Club budgets which reported yields of 90 quintales per manzana and upon extension agent reports of corn yielding 60 quintales per manzana. Corn production was also programed in joint activities with beans whare the output of 48 faregas and 20 fanegas of corn was produced jointly with 18 and 4 fanegas of beans in budgets supplied bv Ing. Guillermo Montenegro.

Bean production was programmed with three distinct levels of technology. Modern inpuss yielded 20 cuintales per nanzana (51), broadcast beans yiclded 5 quintales fer manzona anei traditionally planterl hasus yieldad io quintalas per lomeala (18). 
The strawberry producing activity used florida production data (12) modified by incomplete data from Alajuela and Heredia farms. Yields were programmed at 250 quintaies per manzana. This approximates 14,600 pounds per acre. Good California yields, for comparison, ranged from 48,000 to 60,000 pounds per acre (43) and I srael increased its average yields from 3,000 to 10,350 pounds per acre in six years (35).

Sugarcane production activities were programmed from budgets supplied by the Banco Kacional (18) and the extension agency. Production ranged from 60 tons per manzana to 100 tons per manzana per harvest. In a period ranging from 38 to 48 months, three harvests vere made. Production and inputs were totaled for the entire periods.

Three cassava producing activities were programmed. Traditional methods were represented by a budget which yielded 150 quintales in a 21-month growing period (18). Intermediate yields were received by a budgeted production lasting two years (58). Higher yields, 275 quintales per manzana, were programmed with more modern inputs and longer growing period of 26 months (26). Total production pei month increased with age but quality declined.

Cucumber production activities represented different timing of modern techniaues based upon agronomir. Jata furnished by the Alajuela experiment farm (52). Yie! ds were 140 guintales per manzana.

The sivestpotato produstion activity basad on modern inputs (5) yielded 300 quintales per manzana which tripled the yieid of traditiona! methods reported by the Banco Nacional (18).

A peanut producing activity utilized a budget reported by the Cartago bank (58). Yieidis of 25 uluintales per manzana ware expected. 
Pigeon pea, buckwheat and chickpea production activities were included, based upon the same sources as used for the Palmares-San Ramón study.

Prices were based on an unweighted average for coffee, reported lows of vegetable prices, and estimates of potential industrial prices for tomatoes, peppers, strawberries and citrus. Since the projected horticultural marketing assumed much greater volume than current sales, price predictions were lower than average prices but subject to considerable error.

In the study of the four farms in Acosta, coffee production budgets were supplied by Ing. Rodrigo Cavallini of the San Ignacio Extension Agency. The better methods used fertilizer or other purchased inputs and yielded 10 fanegas per manzana which was considered high for this region. Traditional methods yielded six fanegas and used small quantities of fertilizer and heavy labor inputs. Coffee was grown with oranges and bananas on sume farms with poor yields of both coffze and fruit. Cofiee yielded five and six fanegas and oranges yielded 1,000 to 3,000 fruit per marizana on neglected trees.

An activity used to program the possibilities of technological change was stipplied by Edwin Marín of the Oficina del Café. He budgeted production yielding 14 fanegas per manzana in an adjoining district. An activity was also included representing semi-abandonment and yieiding only two fanegas per manzana.

A high yielding orange producing activit: was included and based upon data taken from foreign sourcos $(28,49)$. This activity yielded 102,000 cranges compared to 53,300 orange's per manzana producted on a farm ir Acosta. 
Corn and bean production was reported with low to very low yields. Joint cropping ploduced $29,6.4$ and 16 fanegas of corn combined with $11,9.6$ and 6.6 fanegas of beans.

The same beef and dairy production coefficients used in the Palmares study were included in the matrix.

Lime production was included with a yield of 400 quintales per manzana based upon Florida data (42).

The inclusion of a blackberry producing activity also was based upen a composite of information from Florida (65) and Costa Rica. Yields of 16,000 pounds per manzana were anticipated.

\section{Assumptions of the Model}

There are certain assumptions and limitations of the model which should be clarified before the results are interpreted. Lirear progl:amming uses profit maximization within a set of constraints as a single criterion for al iocating resources. This would deviate from actual practice especially in those cases where the magnitude of gain is so slight as to not make a more complicated program worth the trouble when compared to a simpler, more easily managed plan of operetions. Also, the model does not take uncertainties and risks into account. Risks, that may be either real or inagined, enter into faim decision making. Yields and prices vary from year to year. The farm operator will actualiy be interesied in maximiang profits only within sone range of acceptable iisk.

The modei forces ail decisions to bo mate at once. Since it is is static model, growth possibilities are not taken into account. This is particularly troublecome in the case of short-term credit and 
operating capital restriction. Because of this feature, the model is conservative insofar as new resources are not permitted to be generated cver time.

All units are considered divisible. This does not cause a froblem except in the case of cattle and labor movement. Theoretically, part-time empioyment could explain fractional units of labor movement. 


\section{RESULTS}

\section{Optimal Cropping Plans}

In general, cropping patterns determined with the initial linear programming model did not greatly differ from the reported practices. With one exception, land was fully utilized during at least part of the year. Unused permanent labor was often available except during coffee harvest. The restrictions on hiring temporary day-wage labor were generally not constraining. Where horticultural crops were considered, operating capital was restrictive. This restriction occurred also on the smaller, poorer coffee farms. Margina! returns to short-term credit, calculated by using reported expenditures as a base, were either zero or well over the established interest rate. Parametric changes found coffee production to be stable in the face of moderate coffee price and yieid dacreases but responsive to technological improvements and credit manipulations. Changes in the availability of credit, the interest rate, the labor supply, and product prices had a much greater effect on the ailocation of resources among the various alternative crops than they had on coffee production. A brief sumary of optimal resource use will be given for each of the 16 farms.

Farmi

The optinal solution of this coffee-robacco farm coinciced with the reported production. Two manzanes were planted to thinly spaced 
corn and tobacco and three manzanas were used to produce coffee. In addition, two manzanas of buckwheat were planted in the dry season. The net returns $(\xi 19,781)$ fell slightly below the farmer-estimated returns $(\xi 22,500)$ because the model included extra labor costs and lower corn prices. Land and burley tobacco contracts were limiting rows with marginal values estimated at $\$ 4,069$ and $\$ 215$, respectively. Temporary labor was hired in October and January. Permanent labor was fully utilized in May and October as well as from November through February where the model permitted coffee harvesting to exhaust the labor supply. A slight excess ( 681 ) in operating capital occurred.

\section{Farm 2}

The second farm from San Ramón was a small specialized coffee producer. The optinal solution for the linear programming model derived for this farm situation also produced only coffee. Net returns in the moriel were $\$ 18,024$ compared to $\$ 15,250$ calculated from the farmer report. The model permitted the use of a higheryielding coffee activity which proved slightly more profitable than the technology actually used. With tobacco activities blocked, the only effective constraint was land. Permanent labor was exhausted only from November through February when coffee harvesting utilized all the labor. The farm optimal solution used $\$ 3,157$ of 44,000 available capital and credit. There were 193.2 fanegas of coffee pioduced.

\section{Farin 3}

This farm produced good coffee yields with very high costs. The model permitted traditional coffee activities on this farm but the five best coffee-producing activities of the region were blocked. The optimai solution contained less-intensive coffee production, 
more-intensive use of the non-coffee land, and no reduction in coffee acreage. Coffee output was reduced 25 percent from the reported output. This change was accompanied by an increase in net income from $\$ 34,130$ to $\$ 35,543$. The optimal plan made heavier demands on management with seven producing activities instead of three. Sales included 750 fanegas of coffee, 52.8 quintales of tobacco, 108.4 quintales of corn, 49.1 quintales of beans, and 16.3 quintales of sesame.

The flue-cured tobacco contract row was exhausted as all three mallzanas permitted for tobacco were pianted in the farm model. Permanent labor resources were exhausted in all months except May and October. Coffee harvesting exhausted the labor supply during November, December, January and February. Temporary labor was hired in March, June, July, August and September.

The optimal plan used less than $\$ 45,666$ of a $\$ 71,100$ operating capital and credit constraint.

Farm 4

The fourth farm studied produced coffee and flue-cured tobacco. Tobacco was the chief money earner with coffee grown to supplement income with very low labor inputs. The linear programming model of this farm situation resulted in considerable changes in resource use. Coffee output was increased from 80 to 225 fanegas and tobocco production was reduced from 90 to 46.8 quintales. In addition, corn, beans, and mixed crops were substituted for tobacio. Saies also included 36.7 quintales of corn, 59.9 quintales of beans, 2.6 quintales of pigeor peas, and 81 pounds of chickpeas. Net returns in the model situation were 631,667 which greatly exceeded the 414,700 estimate of income under reported resource use. 
The model used all available land from July through January, all available operating capital and credit, and all permanent labor in April, June, July, August and the harvest months from November through February.

Temporary labor was hired in January and August. Family coffee harvesting was limited by the family labor supply in Cecember. Hiring labor was not constrained by monthly supervisory limitations which allowed two temporary workers for each family or permanent employee. The tobacco contract allotment was not exhausted.

\section{Farm 5}

The fifth farm specialized in coffee. The maximization of the linear programming model gave results similar to reported resource

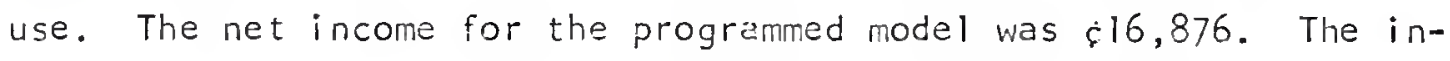
cicase over the reported income of $\$ 15.520$ was explained by shall savings in the accounting of harvesting costs and the fact that some of the reported expenditures were long-term irvestments.

In the model, permanent labor was fully employed during the harvest period from November through February. All 10 manzanas of land were used and family coffee harvesting was limited by the availability of family labor in Desember. An excess in the operating capital and credit row cccurred in the model because the reported annual expenditures included some long-term investments.

The farm produced 190 fanegas of coffee using the highest vielding coffee activity permitted in the model.

\section{Farm 6}

The sixtin farm studied was a sma?l coffee farm with an absentee owner. The fälin rodel allowed corfee yiclds slightly above those 
reported by the farm. This reduced the net loss to $\$ 760$. This loss occurred with an increase in both yield and coffee acreage above the reported numbers.

In the model, all four manzanas of land were planted to coffee for profit maximization. This occurred with 0.25 manzanas of new coffee planted.

The optimal solution maximized returns to land. Credit and operating capital were not limiting in the model, since reported preharvest expenditures were $\$ 4,000$ compared to a $\$ 2,565$ optinal preharvest expenditure. A large surplus of permanent labor occurred in all months except during the coffee harvest feriod.

The new coffee planting was not stable in the face of interest changes on the required investment. The rate initially used was 6 percent representing a minimum charge which government banks have used in a policy to subsidize agricultural investment. The new coffee was not planted if interest charges rose 0.8 percent. Beans and sesame were planted instead of coffee. The farm loss increased from $\$ 760$ to $\$ 780$.

\section{Farm 7}

The results of proglaming the seventh farm more than doubled reported net farm income from $\$ 3,345$ to $\$ ?, 147$. In the optimal solution, coffee production was expanded with 0.26 manzanas pianted to new coffee. Dther production activities included were sun-cured tobacco, corn and beans. Optimal cutput, before parametric changes, was maximized with the production of 62.0 fanegas of coffee, 19 quintaies of tobacco, 72.8 quintales of corn, and is.9 quintales of beans. 
The optimal production exhausted the credit and operating capital row, land rows from september through January, and the sun-cured tobacco contract. Permanent labor was exhausted in all months except July. Temporary labor was hired in all months except July and August. Labor supervision did not limit hiring temporary jabor in any month.

The newly planted coffee was not stable when interest charges on investments were increased. Interest charges would block new plantings when the rate was increased 0.1 percent.

\section{Farm 8}

The eighth farm model results optimized resource use with the production of 19 fanegas of coffee, 7.8 quintales of sun-cured tobacco, 24.0 quintales of corn, 5.4 quintales of beans, and 6.5 quintales of sesame. Optimal net returns were 44,005 compared with a reported income of $\$ 2,653$. Coffee acreage in the optimum program was the same as the farmer's reported acreage.

Credit was severely restricted on this small farm. The shadow price indicated that an additional colon of credit or cperating capital could return $\$ 2.96$ additional net income.

Land was fully utilized except in the month of February. Extra labor was available in all months except during the coffee harvest season. No temporary labor was hired. The restriction that alioved 0.5 manzanas of sur-cured tobacco was rot useo up.

\section{Fôrm 9}

The nintir farm produced coffee with modern inputs. The model included activitios for horticultural crop profuction. The farm maximized income with coffee monocul Lure wich yielded $\$ 86,761$ net returns. The iamer's estimete of net returns was g90,000. Expenci- 
tures for temporary labor were underestimated which limited the operating capital and credit row. The monthly labor supplies were fuily used in January, February, June, July, September, November and December. Temporary labor was hired in June, July and September. Supervision limitations did not restrict temporary labor hiring.

\section{Farm 10}

Analysis of the tenth farm showed that an increase in farm income could accompany crop diversification. Net returns were increased from $\$ 17,160$ to $\$ 29,439$ when optimal use of other crops replaced coffee. However, this farm was reportedly upgrading coffee technology in order to receive $\$ 30,000$ expected net returns with coffee monoculture. The optimal cropping pattern included five different crop-growing activities producing 213.3 fanegas of coffee, 48.0 tons of tomatoes, 148.0 tons of sugarcane, 708.0 quintales of sweetpotatoes and 3.14 quintales of chickpeas. Coffee trees were removed from 4.3 manzanas of land. The permanent labor supply was used up in January, February, April, Aligust, September, November and December. Temporary workers were hired in January, February, September and December. The operating capital and credit constraint was liniting in the model. Supervisnry capacity did not limit hiring temporary workers.

Farm 11

On the eleventh farm, programmed optimal solutions did not change coffee acrage from the reported land use. Dther crops replaced pineapples. The reported net returns of ${ }_{r}$ it? 980 exceeded the optimal incone of $\$ 21,536$ of the model. This difference occurred because the model contained fruit prices for industitial use while the farmer produced 5.5 manzanas of pireapple for the fresh fruit market in 
San José. The high domestic market prices of fruits and vegetables were not used in the model, since these prices could not be received if any significant portion of coffee resources were shifted into horticultural production.

Sales to maximize net revenue included 100.0 fanegas of coffee, 2.0 quintales of beans, 710.9 quintales of limes, 13.0 tons of tomatoes, 0.8 tons of green peppers, 236.0 tons of sugarcane and 254.5 quintales of sweetpotatoes. Land was fully utilized from November through April. Permanent labor was fully utilized in al! months except october. Temporary labor was hired in January, February, April, June, August, September and December. The capacity to supervise labor was not an effective restriction in any month; however, slack supervisory caparity was reduced to 29.4 hours in January. The operating capital and credit row limitêtion was exhausted. Rolational limitations were not restrictive.

Farm 12

The twelfth farm was programmed with only the poorer coffeeproducing activities of the Alajuela region. The farm reported poor coffee yields averaging 10 fanegas per manzana. The programmed optimal solution contained the traditiona! coffee activity which yielded nine fanegas per manzana. The activity based on the reported resourcc use was dominated by another coffee-producing activity. Net returns were maximized wi th the production of coffee, corn and beans ard limes which netted 67,078 in the model. These returns were higher than the $\$ 6,122$ calculated from the farmer report. Farm output included 22.5 fanegas of corice, 24.1 quintales of corn, 4.8 quintales of beans and 717.2 guintales of limes. 
Excess permanent labor occurred in all months except the coffee harvest period. No temporary labor was hired. All coffee was harvested with family labor. Credit was severely restricted.

\section{Farm 13}

The thirteenth farm was programmed using two different sets of fruit prices representing industrial prices with and without a processing plant located in the Acosta region. Two completely different diversification pictures are presented since it is questionable whether or not the area could support a processing plant. First, higher fruit prices were used to evaluate diversification alternatives. Limes were priced at ф́i 3.00 per quintal, blackterries at $\mathbf{l}$ l.00 per pound and oranges at $\$ 4.00$ per hundred. The results of profit maximization in the model showed a sizable departure from the reported resource use. This does not dispute a theory of farmer profit motivation since completely different horticultural alternatives were placed in the model. Nevertheless, the model shows that if fruit prices were moderately high and stable, considerable changes would occur and coffee output would be reduced on farm 13 .

Profits in the model were maximized with $\$ 89,948$ netted from mixed coffee and lime production. Coffee tree destruction was programmed for 32.94 manzanas. Credit was 1 imited, causing both semiabandoned methods and traditional lowyield methods of coffec to be used in coffee production. Permanent labor was fully utilized in January, February, May, July, August, September: October, Moventer and December. Temporary labor was hired in January, February, llay, luly, August and september. The limit on superyisior for temporary workers was not effective. 
Farm production was comprised of 195.6 faregas of coffee and 17,780 quintales of $i$ imes. This coffee output was reduced from the present output of 900 fanegas. However, wi thout favorable fruit prices, the maximum income for farm 13 was $\$ 67,694$. Therefore, the reported income of $\$ 66,878$ closely approximated the maximum of the model when only traditional crops were grown and coffee output was 900 fanegas. Other sales included 333.5 quintales of corn and 126.5 quintales of beans. In the model, a higher-yielding corn and bean activity substituted for the corn and bean activity actually reported in use.

In the second analysis, low fruit prices were programmed at \$9.00 per quintal of limes, $\$ 0.50$ per pound of blackberries and $\$ 3.00$ per hundred oranges. Wi th the lower fruit prices, the available credit and operating capital row was not a limiting factor. All coffee land remained in coffee but no new coffee was pianted. The most advanced tecinology permitted by the model was used to produce corn and bearis. Fermanent labor was exhausted in all months except April and June; however, temporary labor was hired only in January, March, July, August, September and October. All but 96 fanegas of coffee were harvested with contract labor.

Farm 1!

As with the preceding farm, the fourieenth fiam was programed using high and low fruit prices. With the higher fruit prices, optimization of the model resulted in considerable departure from reported practices. Al though no coffee trees were renoved, output of coffee was reduced from 70.0 to 13.4 fanegas with coffee production activities using low-yield and semi-abandoned methods. Nine 
manzanas of limes utilized the non-coffee land and 3,600 quintales of limes were produced. Net returns in the model were $\$ 24,222$. The farm reported income was much lower with $\$ 11,446$ netted from traditional grain crops and common coffee practices.

The operating capital and credit row were severely limited in the model with a marginal return of $\$ 1.51$ per $\$ 1.00$ of credit. Permanent labor was exhausted except in March and April. The model resulted in hired labor in January, February, liay, June, July, August and September. Labor supervision was not a limiting factor.

The optimai solution in the model for farm 14 was completely different when lower fruit prices were used to represent alternatives without a nearby processing plant. The maximization of net returns with traditional crop alternatives resulted in 70.0 fanegas of coffee outplit. Maximum net returns in the model were higher than reported returns, $\$ 16,718$ compared to $\$ 11,446$. The increase was accomplished with higher returns to corn and beans which were programmed with moderately poor yields that greatly exceeded reported farm production. Nevertheless, insofar as coffee production was concerned, the model results coincided with the actual reported production.

Maximum net returns occurred with the production of 70.0 fanegas of coffee, 261.0 quintales of corn and 99.0 quintales of beans. Operating capital vâs limiting and the family labor supply was exhausted in all moriths except March, April and June. Labor was hired in May, August, September, October, November and Dezember.

Farm 15

The fifteenth farm aiso was given two different fruit price situations. Wi hh high fruit prices used first to represent production 
potentials given a processing plant in the region, the farm model maximized net returns at $\$ 5,459$. In comparison, reported production netted only 61,403 . Profits were maximized by shifting 0.26 manzanas of coffee into lime production. Farm output included 17.4 fanegas of coffee and 105.9 quintales of limes.

The farm model used all credit and operating capital available. Labor was fully used only from October through February during the coffee harvest. Land was fully utilized and no temporary labor was hired. Of the $\$ 5,459$ netted on the farm, $\$ 2,353$ were received from off-farm coffee harvesting.

When lower fruit prices were used in the linear programming analysis of farm 15, all land was planted to coffee. Farm production in the model slightly exceeded reported coffee output. Income was above that reported because the model included cemporary outside income from coffee harvesting as part of farm income. Of the $\$ 5,209$ net returns, $\$ 2,308$ was income from coffee harvesting work on other farms. Commonly grown coffee replaced the reported poorer yielding coffee-arange activity.

Coffee production maximized the returris to land and harvest time labor. Credit vas not a limiting resource when low fruit prices were used in the model. The family labor supply excecded all rionthly demands for labor and no labor was hircd. The excess family labor was sold during the coffee harvest feriod and was unused the remainder of the year. Twenty fanegas of coffec were prorluced with the optimal use of resources.

Farm 16

The sixteenth farm was aiso programined with high and low fruit 
prices. The farm had reported 7.5 fanegas of coffee production from 1.5 manzanas of coffee. When high fruit prices were used, the maximization of profits shifted resources into lime production and coffee land was utilized in semi-abandoned coffee production. Net returns reached $\$ 4,307$ when maximized which surpassed the $\$ 1,339$ calculated as expected income with reported resource use. However, $\xi 2,273$ out of the $\$ 4,307$ represented harvest labor sales.

Credit was severely restricted when high fruit prices reflected a strong local market. Over \$5.30 marginal returns were estimated per colon of additional credit. Almost 1.2 manzanas of land were idle in the optimal solution. Output included 3.0 fanegas of coffee, 382.4 quintales of limes, 18.2 quintales of corn and 27.3 quintales of beans. Permanent lator was fully employed only during the coffee harvest and no temporary workers were hired.

When low fruit prices were used in the programming model, limes were excluded and resources were allocated to traditionally grown coffee and low-yielding corn and bean activities. Credit was severely restricted with a marginal return for operating expenditures estimated at $\$ 3.22$ per $\$ 1.00$. Profits were maximized with 0.77 manzana of land idle. Excess permanent labor occurred in all months except during the coffee harvest. No temporary viorkers weie hired. Optimal sales included 9.0 fanegas of coffee, 54.0 quintales of corn and 32.2 quintales of beans. Income was maximized at $\$ 3,612$, of which $\$ 2,145$ canle from labor seliing for coffee harvesi.

\section{Policy Analysis}

\section{Education for Better Farm Manacement}


programed resource use given the price and credit relationships faced by the farmers without a positive policy to foster crop diversification. Nevertheless, the changes in resource use may be attributed to a general policy of better farmer education and expanded extension work that would be required before part of the alternatives programed could be put into practice.

Therefore, the first policy consideration to be considered represents education for better farm management. It is often heard that farmers produce coffee because of non-econcmic motivations, that they are reluctant to change, or that they maintain traditional cropping patterns out of ignorance. Table 2 shows comparisons between the reported and optimal values for net returns and for coffee outputs. The results do not indicate that irrational cverproduction of coffee was prevalent. Of the 16 farms studied, only two farms demonstrated overproduction of coffee. Overproduction on farm 3 could be attributed to overintensification where returns could be increased by reducing inputs and yields. The huge quantities of fertilizer reported represented either mismanagement or hidden investment. Overproduction on farm 10 occurred because either sugarcane or horticulture gave returis high enough to replace part of the moderately high-yielding coffee. The lower programmed coffee output on these two farms was countered by higher output on other farms.

While the sample is too small to support broad generalizations, some overproduction of coffee beyond that quanticy dictated by strict

Hidden investment in this case may arise when increased annual expenditures occur for a short pericd before yialds are increased to full potential. 
Table 2. Comparisons between reported and optimal incomes and coffee output

\begin{tabular}{lrrrr} 
& & & & \\
\cline { 5 - 5 } Farm $^{2}$ & Reported & Optimal & Reported & Optimal \\
\hline & (colores) & (colones) & (fanegas) & (fanegas) \\
1 & & & & \\
2 & 22,500 & 19,781 & 82.8 & 82.8 \\
3 & 15,250 & 18,025 & 179.9 & 193.2 \\
4 & 34,130 & 35,543 & $1,000.0$ & 750.0 \\
5 & 14,700 & 31,667 & 80.0 & 225.0 \\
6 & 15,520 & 16,877 & 190.0 & 190.0 \\
7 & $-7,760$ & -760 & 56.3 & 76.0 \\
8 & 3,345 & 7,147 & 45.0 & 62.0 \\
9 & 2,653 & 4,005 & 15.0 & 19.0 \\
10 & 90,000 & 86,761 & $1,000.0$ & 997.2 \\
11 & 17,160 & 29,489 & 300.0 & 213.3 \\
12 & 42,980 & 24,536 & 100.0 & 100.0 \\
$13 \mathrm{~A}$ & 6,122 & 7,078 & 25.0 & 22.5 \\
138 & 66,878 & 89,948 & 900.0 & 195.6 \\
$14 \mathrm{~A}$ & 66,873 & 67,694 & 900.0 & 900.0 \\
$14 \mathrm{~B}$ & 11,446 & 24,222 & 70.0 & 18.4 \\
$15 \mathrm{~A}$ & 11,446 & 15,718 & 70.0 & 70.0 \\
$15 \mathrm{~B}$ & 1,403 & 5,459 & 10.0 & 17.4 \\
$16 \mathrm{~A}$ & 1,403 & 5,209 & 10.0 & 20.0 \\
$16 \mathrm{~B}$ & 1,339 & 4,307 & 7.5 & 3.0 \\
& 1,339 & 3,612 & 7.5 & 9.0
\end{tabular}

The letters $A$ and $B$ are used to designate different fruit pricing used in Acosta. A's are used to indicate the situations using high fruit prices and $B^{\prime}$ s are used to indicate the situations using low fruit prices. 
profit maximization is indicated. Most of the potential for income improvement occuired with the land not planted to coffee. Labor selling activities for the coffee harvest made sizable contributions to the higher optimal incomes of the smaller farms.

of the 20 farm situations studied, three reported higher incomes than the optimal permitted in the model. In farm 1 and farm 9 this difference was due to a lower wage cost estimation in the farmer report than was permitted in the model. More significantly, the reduced optimal income on farm ll came about because the model only a! lowed pineapple sales for export or industrial use while the farm produced for a much higher domestic fresh-fruit market.

Markedly increased incomes were accompanied by reductions in coffee output only when high return fruit or vegetable crops were considered as alternatives. Thus the higher incomes are asscciated with higher risks. Optimal allocation of resources reduced coffee output 3.06 percent on the eight farms of the Palmares-San Ramón area, and 6.46 percent on the four farms of the Alajuela area. For Acosta, optimal rescurce allocation increased coffes output 1.16 percent when low fruit prices were used but decreased coffee output 76.26 percent when high fruit prices were used. A sizable reduction ocrurred in the Acosta output only when high yielding alternatives were compared with low yielding coffee.

Changes which reduced coffee output brought activities into production which utilized more modern inputs than the altermative crops usually receive in Costa Rica. This gives rise to a question of whether or not the same relationships would exist if new coffee growing activities reprosented higlie: levels of technology in coffee 
production. In order to keep the model representative of current techmological proficiency, certain high-yielding coffee activities were flagged from use in 17 of the 20 farm situations. Then parametric programming was used to increase coffee transfers until reported yields of the better farms were equaled. The results showed that on some farms modernization would be justified if over 60 percent of anticipated yields were obtainable. In the Alajuela and Palmares-San Ramón areas, it would pay most farms to adopt modern inputs if over 80 percent of the recorded yields were cbtainable. In Alajuela technological change permitted yieid increases from 20 to 25 fanegas per manzana. In Paimares-San Ramón the yields were increased from 19 to 27.6 fanegas per manzana. Yields were increased from 10 to 14 fanegas per manzana in Acosta.

The resuits of the programmed technological advances are given in Table 3. In the Alajuela and Palmares-San Pamón farm situations, optimal coffee output was increased 72.4 percent and farm income was increased 110.23 percent when higher-yielding coffee activities modified the output of nine farms. In the Acosta programs, coffee output was increased 198.81 percent and net income was increased 9.38 percent when technological changes for coffee were permitted in the four farm situations when high fruit prices were used. Given low fruit prices, coffee output only increased 15.98 percent but income increased 26.98 percent in the Acosta farm sizuations.

Higher levels of tecinology brought smill increases in coffee acreage on a number of the farms. The planting of nevi coffee ias limited by credit restrictions. The gains in programma income were sufficiently high to motivate change if the improved technology can 
Table 3. The effects of improving coffee production technology on coffee production and income

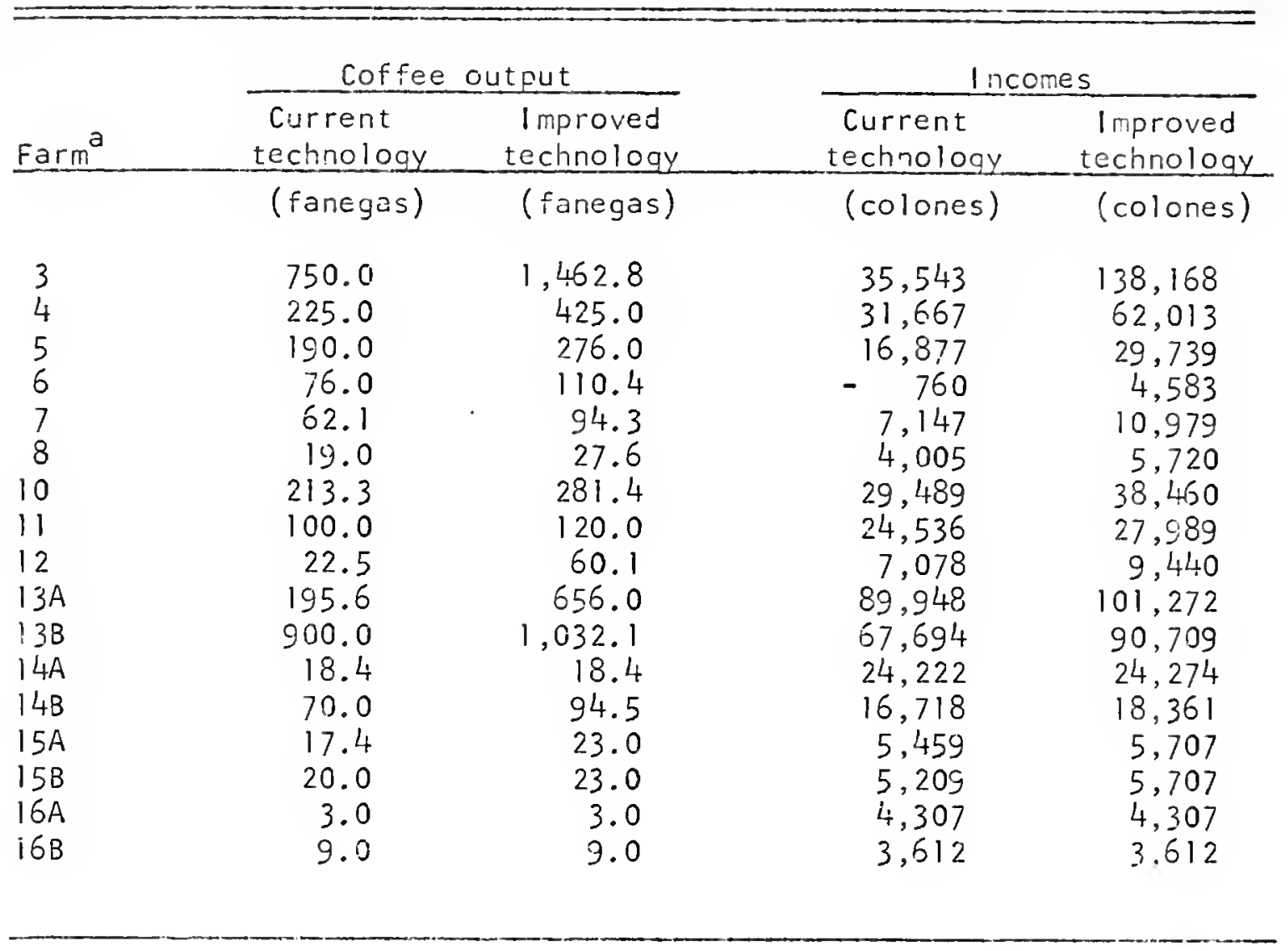

a The letters $A$ and $B$ are used to designate different fruit pricing used in Acosta. A's are used to indicate the situations lising high fruit prices and B's are used to indicate the situations using low fruit prices. 
increase production to the ievels reported on the better farms. The higher yields obtainable in Alajuela and Acosta resulted in greater increases in income in comparison with the Acosta farms. Coffee production, therefore, is expected to increase unless positive aids to diversification or production controls are put into effect.

Comparisons between optimal coffee production and maximum net returns for traditional versus new enterprises are shown in Table 4. On the Alajuela farms, returns from sugarcane approached those of horticultural crops and optimal coffee output was not reduced when the new crops were included among the alternatives. However, incomes vere increased where coffee yields were limited to 20 fanegas per manzana. Actually, the higher credit requirements of the horticultural alternatives caused the optimal coffee tree destruction to be lower when horticultural crops were included on Farm 10.

In the Acosta farm situations the exclusion of fruit production alternatives lowered optimal income and caused a sizable increase in coffee output. Farm 13 and farm 14 had sufficient capital and credit to respond to fruit production opportunities with sizable increases in income. The addicional income potential of fruits and vegetables was limited on the smaller farms by a shortage of operating capital and credit.

\section{Taxation or Price Reduction}

The stability of coffee production in farm management plans was further examined with price declines parometrically programed into each farin situation. Table 5 shows the effect of price declines cr. coffee output. Reduced cutput with 5.00 per fanega price declines was I imited to the blocking of new plantings of coffee trees and the 
Table 4. Comparisons of optimal incomes and coffee outputs with traditional versus new enterprises on farms in Alajuela and Acosta

\begin{tabular}{|c|c|c|c|c|}
\hline \multirow[b]{2}{*}{ Farm } & \multicolumn{2}{|c|}{ Coffee output } & \multicolumn{2}{|c|}{ Net income } \\
\hline & $\begin{array}{l}\text { Traditional } \\
\text { enterprises }\end{array}$ & $\begin{array}{c}\text { New } \\
\text { enterprises }\end{array}$ & $\begin{array}{l}\text { Traditional } \\
\text { enterprises }\end{array}$ & $\begin{array}{c}\text { New } \\
\text { enterprises }\end{array}$ \\
\hline & (fanegas) & (fanegas) & (colones) & (colones) \\
\hline 9 & 997.2 & 997.2 & 86,761 & 86,761 \\
\hline 10 & 163.8 & 213.3 & 22,586 & 29,489 \\
\hline 11 & 100.0 & 100.0 & 22,239 & 24,536 \\
\hline 12 & 22.5 & 22.5 & 7,003 & 7,078 \\
\hline 13 & 900.0 & 196.5 & 67,694 & 89,948 \\
\hline 14 & 70.0 & 18.4 & 16,718 & 24,222 \\
\hline 15 & 20.0 & 17.4 & 5,209 & 5,459 \\
\hline 16 & 9.0 & 3.0 & 3,612 & 4,307 \\
\hline
\end{tabular}




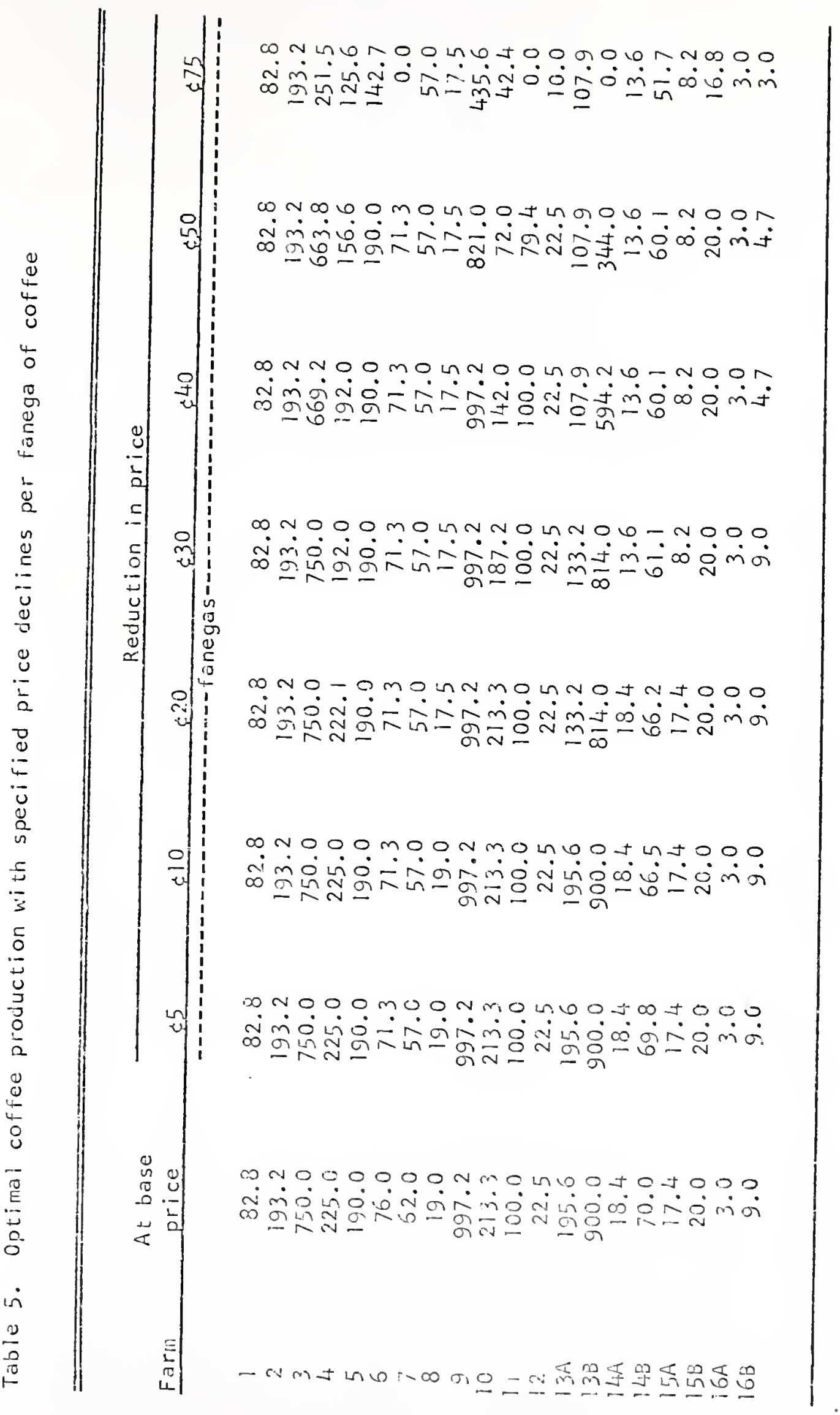


substitution of corn and beans for low-yielding coffee on farm 14 . Taxes up to $\$ 10.00$ per fanega would have little effect on coffee output of the farms programmed. Except for the newly planted coffee, coffee production was not responsive to price declines up to $\$ 20.00$ per fanega. High-yielding coffee and semi-abandoned coffee were the most stable. With high coffee yields, the alternatives are poorly competitive and with very low-yields, stability is assured by severe credit limitations. Resources were shifted away from coffee when the coffee price fell to new market price levels.

Table 6 shows the effect of price declines on coffee acreage. Coffee acreage was more stable than coffee output. Coffee land was nctably more stable on the smaller farms as price declines were programmed.

The effect of price declines on farm incomes is shown in Table 7. Price deciines reduced income more rapidly than output and had the strongest efrect on those farms highly specialized in coffee production. For example, given a $\mathbf{c}^{40}$ per fanega price decline, income fell 54 percent on the three largest coffee producing farms and on!y 22 percent on the farms with optimal production less than 100 ganegas. Met returns on farm 2, farm 5, farm 9 and farm 13B, all of which specialized in coffee production, were reduced over 50 percent by a \$50 per fanega price decline. Of those fams specializing in coffee production, only on falm lo did diversification possibilities hold income above 50 peicent of initial levels when price was reduced 25 percent. In the Acosta farm situaiions, high fruit prices resuited in both higher incomes ard greater iricome stability in the face of coffee price declines. The effect of a frice decline on income was 


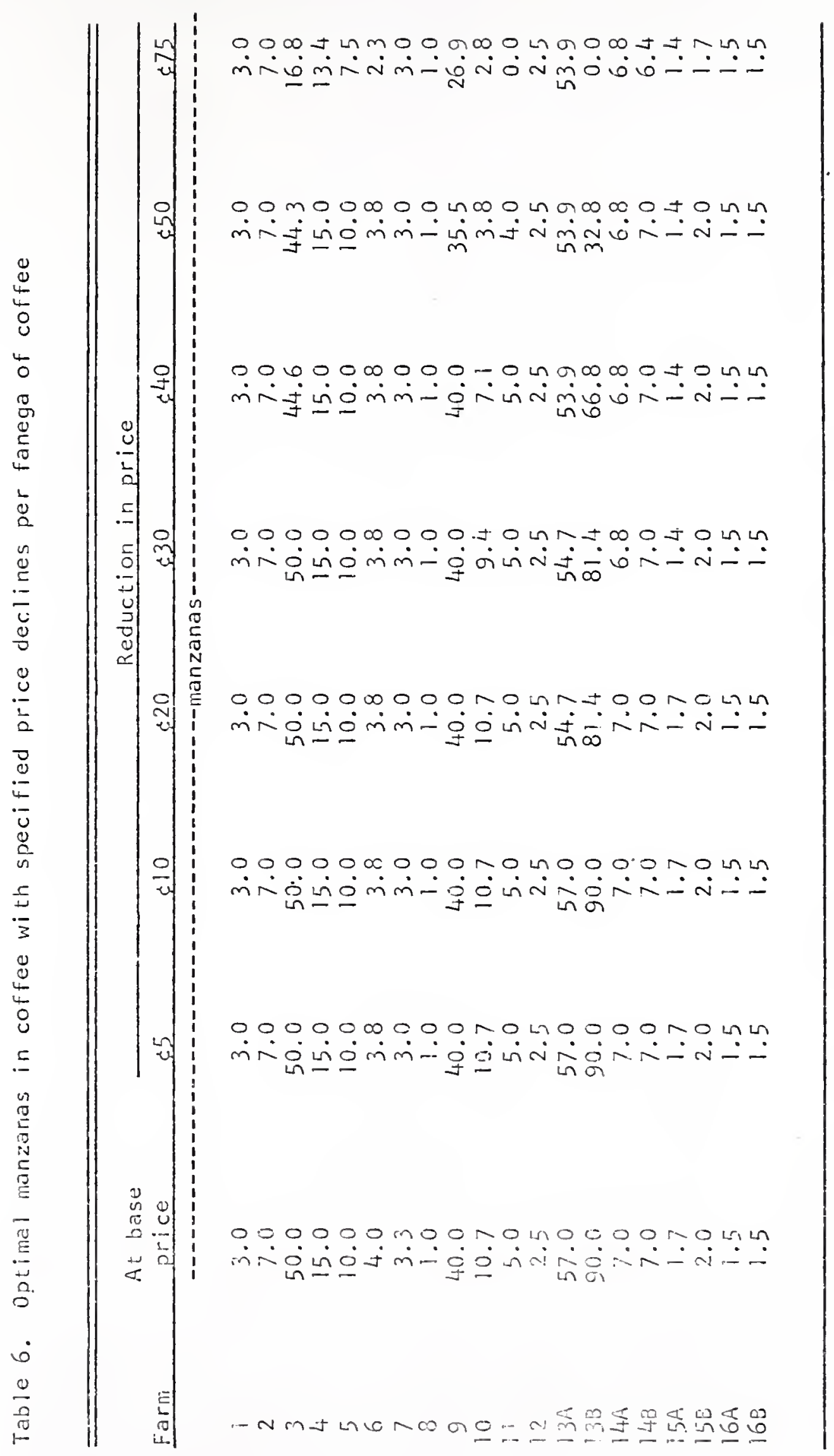


元

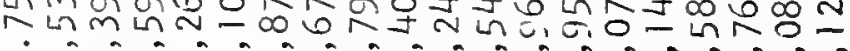

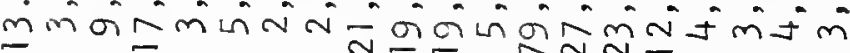
I 1

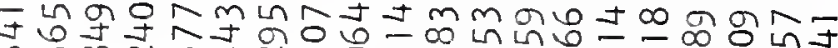
6 ma Nmm N

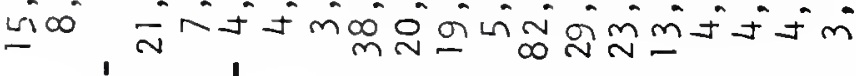

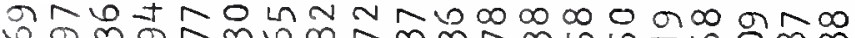
웡 OO

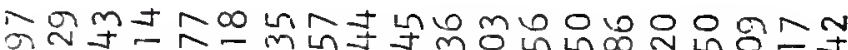

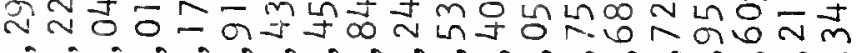
ニミm

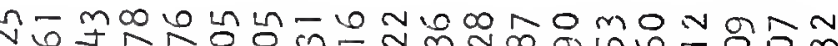
- - L - O

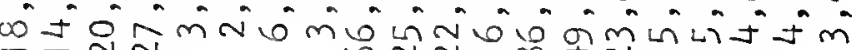

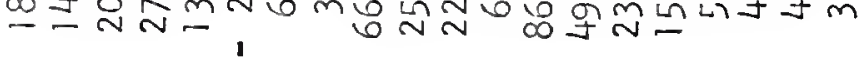

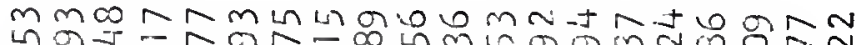

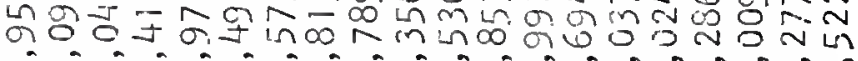
0

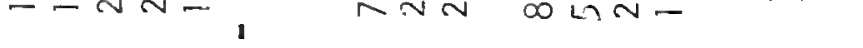

A

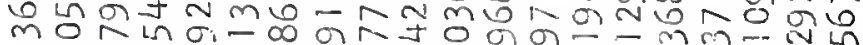

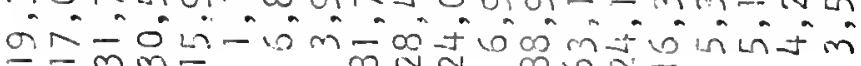
- mm- Dow

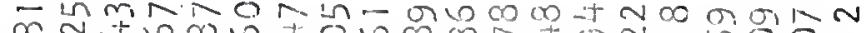

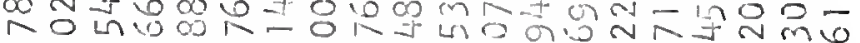
.

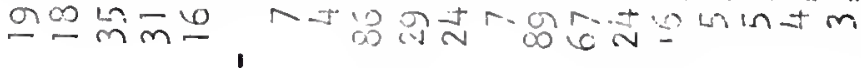


greater on the farms from the Palmares-San Ramón area where expandable alternatives fell further behind coffee in terms of net returns.

The alternative crops that increased first as coffee prices were programmed downward are shown in Table 8. In the Palmares-San Ramón area the farms first responding to a price decline were those with unused tobacco allotment. Among the Alajuela farms studied the larger farms responded first to a price decline. This also held true among the farms from Acosta although irreguiarities occurred with respect to which set of fruit prices were used.

\section{Payments for Coffee Removal}

The programmed effect upon coffee output of annual payments for coffee tree removal is shown in Table 9. Farm 1 , farm 2 and farm 9 were not responsive to removal subsidies because of high returns to coffee. Farm 16 was not responsive because of severe credit limitations.

Annual payments equal to 20 percent of gross coffee earnings per manzana were effective in changing optimal resource allocation in five of the 2.0 farm situations studied. Given a 25 percent discounted price for 25 percent of the output of coffee, the payment of 20 percent of bese gross returns ccula be made for the withdrawal of coffee production without extra taxes or loss to coffee producers. The following formula can be used for calculating a self-paying subsidy for coffee removal. Let the coffee frice be unchanged as coffee in excess of the quota is taken out of produstion.

Then:

$$
\frac{P T+(P-D P) N}{T+N}=\frac{P T}{T+S N}
$$


Table 8. Alternative crops increased first by declines in coffee prices

\begin{tabular}{|c|c|c|}
\hline Farm & $\begin{array}{c}\text { Price reduction } \\
\text { per fanega }\end{array}$ & Crop increased \\
\hline & (colones) & \\
\hline 1 & 100 & None \\
\hline 2 & 91 & Beans, sesame \\
\hline 3 & 40 & Beans, corn \\
\hline 4 & 15 & Tobacco, beans \\
\hline 5 & 57 & Beans, sesame \\
\hline 6 & 58 & Beans, sesame \\
\hline 7 & 90 & Castorbeans, milk \\
\hline 8 & 15 & Tobacco \\
\hline 9 & 21 & Sugarcane, beans \\
\hline 10 & 22 & Tomatoes, sugarcane \\
\hline 11 & 43 & Limes, peppers \\
\hline 12 & 60 & Limes \\
\hline $13 A$ & 14 & Limes \\
\hline $13 \mathrm{~B}$ & 14 & Corn, beans \\
\hline $14 \mathrm{~A}$ & 25 & Limes \\
\hline $1 ! 8$ & 55 & Corn, beans \\
\hline $1 \equiv A$ & 29 & Limes \\
\hline $15 B$ & 58 & Corn, beans \\
\hline $16 A$ & $i 00$ & None \\
\hline $16 B$ & 32 & Corn, beans \\
\hline
\end{tabular}




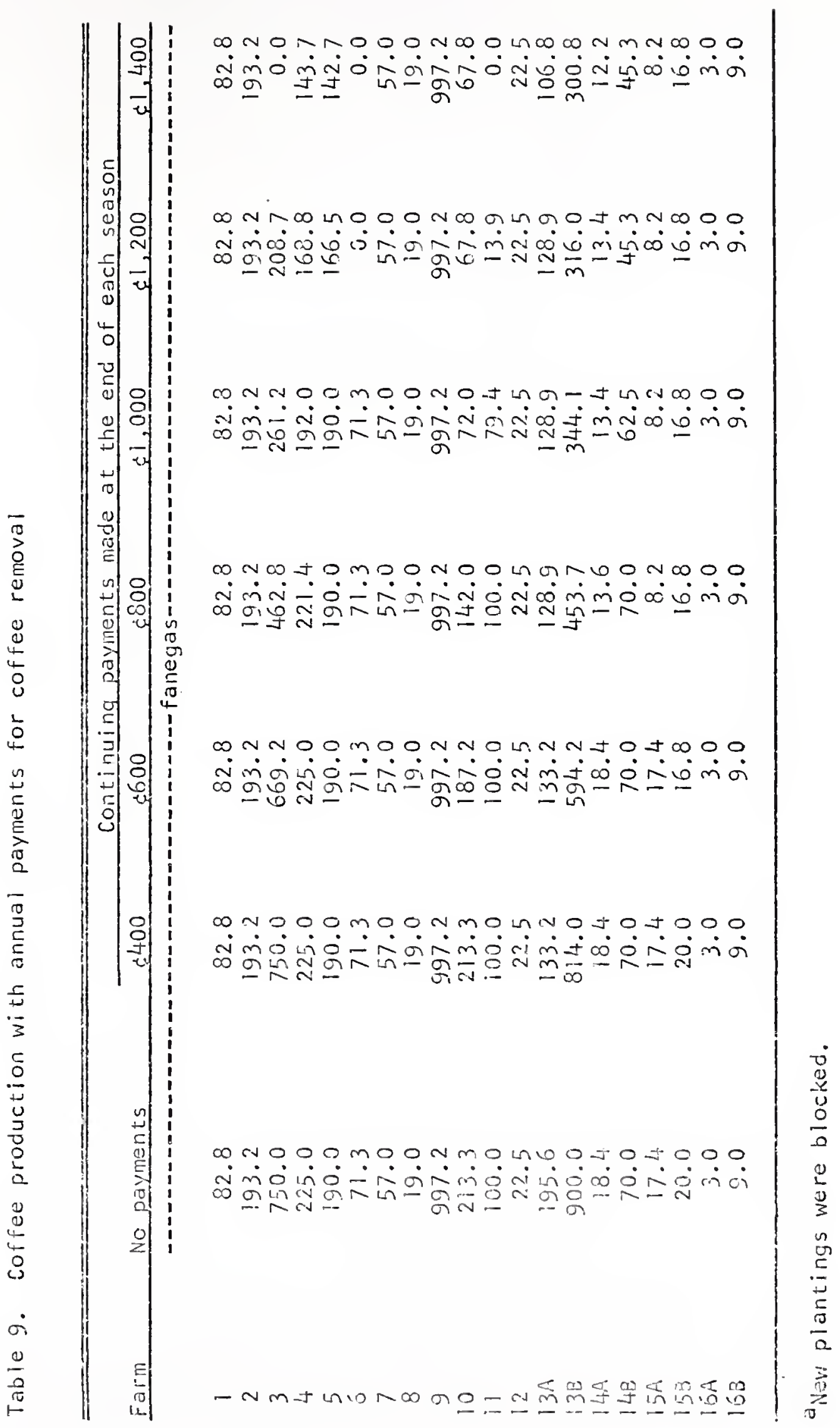


and

$$
S=\frac{T D}{T+N-N D}
$$

where:

$$
\begin{aligned}
& P=\text { price in traditional market, } \\
& D=\text { discount for sale in new market, } \\
& T=\text { traditional market quota, } \\
& N=\text { surplus over quota, } \\
& S=\text { share of payment for exiting firms. }
\end{aligned}
$$

This indicated that coffee could be removed from farm 3, farm 4, farm 10, farm $13 A$ and $13 B$ with a scheme to pay for coffee removal out of total sales revenue without lowering the average price to producers. However, such a scheme would reduce coffee cutput over 10 percent only on farm 3, farm 10 and farm 13A. A shortage of operating capital blocked coffee removal since available credit was reduced by the cost of coffee tree removal.

Arnual payments, as shown in Tabie 10 , either increased or did not affect farm income. One would expect such a program of seiffinancing allotment payments to be politically acceptabie since it would not lower the income for any farm. However, the offect upon coffee production appears to be relatively low with respect to the quantities of coffee produced above traditional market quotas. Additional money could be made available from the Diversification Fund of the International coffee Agreement but even with ihis exald subsidy the annual payments are unlikely to motivate much change. If $\$ 0.30$ per quintal of sales were made available foi this subsidy, annuai payments could be increased less than $\$ 20$ per fanega renoved, assuming that payments were spread over io percent of the base production. 


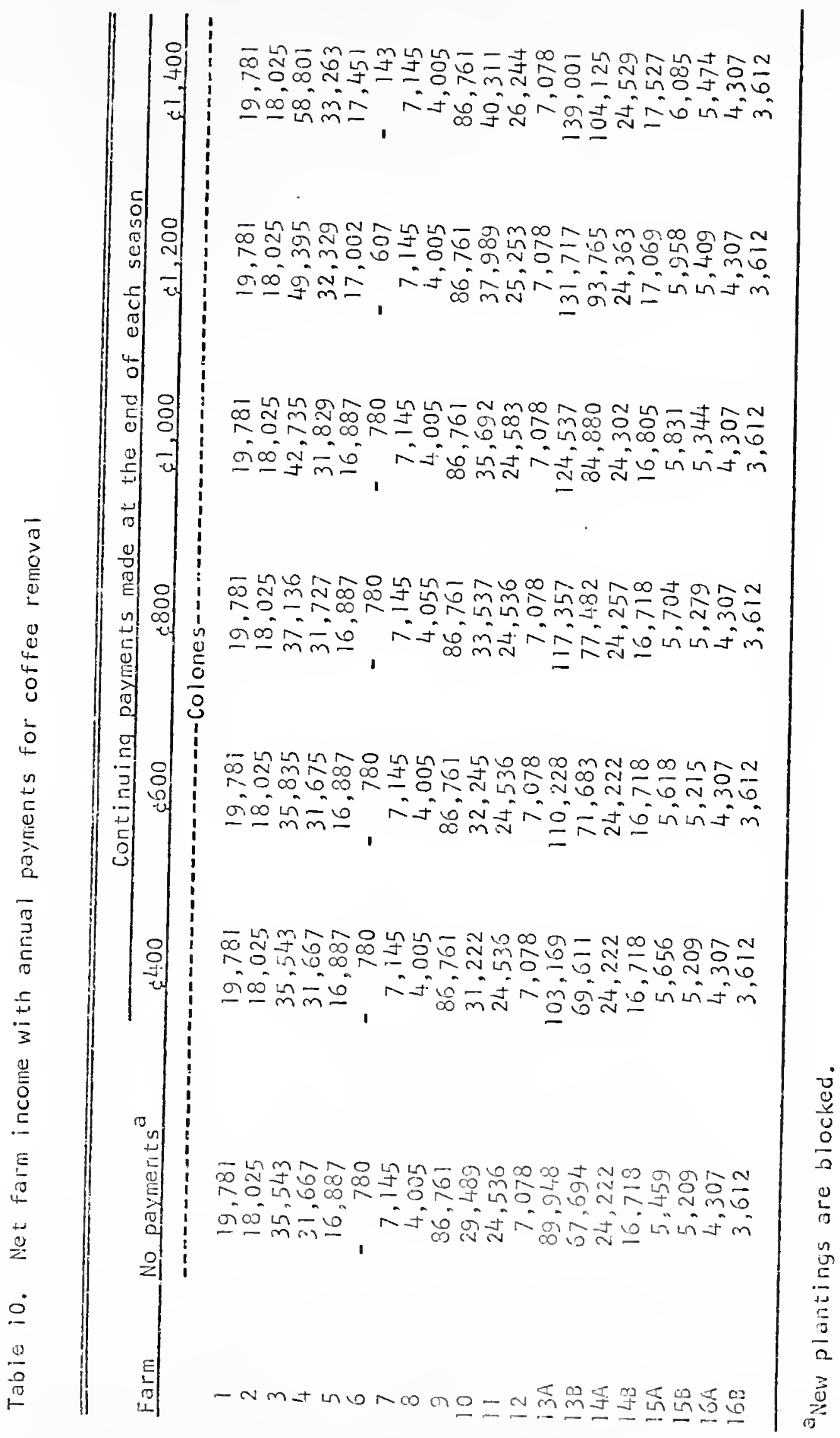


This could increase total payments to approximately $\$ 60$ per fanega. Therefore, before annual payments may effectively remove coffee, the alternative use of resources must give returns competitive with coffee and ample credit must be available to finance such alternative activities.

Payment for coffee removal could be more efficacious if made in a lump sum provided that the marginal interest rate facing the farm operat or is well above the rate at which money is available from bank sources. A lump sum payment equal to the earning differential between coffee and its next best alternative divided by the marginal interest rate for the farmer would be necessary to motivate rational change. Poorer farmers with scarce capital and poor credit standings would be most responsive to such payments if they were given the knowleoge required to change traditional cropping patterns.

The value of a lump sum payment is shown in the following example. Assume that the government can borrow money at 10 percent annually for a 10-year period and that a farmer's marginal incerest earning rate is 30 percent. Then the cost of generating a perpetual psychic income flow of $\$ 100$ per year is $\$ 50$ for each of 10 years. Higher farmer interest rates or extended pay-off periods would further reduce the annua! cost of generating a given psychic income flow.

Because of the difference between bank rates and nargina! interest rates for near stosistonce farmers, lump sum al botment payments would cheapen the payments requiled to motivate change. Instailment payments ceriputed as a share paynent for destroyed coffee couid be paid to a government fund out of coffee export sales wi thout lowering the average price paid to remaining producers. The government fund then 
could borrow to pay lump sum allotments for coffee removal. If the above example of 30 percent farmer marginal interest holds true, then the cost of generating an income flow is halved and changes in output can be motivated through a program of allotment payments in 10 -year installments from coffee sales without lowering average price. Limitations of credit affecting the outputs and incomes would be removed as the subsidy payments would be a source of operating capital.

The cropping pattern encouraged by subsidy payments for coffee removal is similar to the changed output programmed with coffee price deciines. Favored crops are listed in Table 11.

\section{Price Differentiation}

Frice differentiation is theoretically efficient in that it permits the national marginal returns for coffee to be passed back to the farmer. Output of coffee should be reduced or held constant while income is either increased or unchanged. One difficulty in applying this measure is the establishment of the quota for the traditional, higher-priced market. If optimal coffee production is above the historical base used to calculate the traditional market quota, coffee price averages will tend to be lowered. If optimal coffee froduction falls below historical production, the price averages will tend to be increased. If new crops shift resources away from coffee in the initial optimal solution, higher marginal returns to coffee may causa an increase in coffee production as some resources are shifted back into coffee production.

Table 12 shows optimal incomes and coffee outputs with single and differentiated coffee prices. Of those farms wi ih increased incomes, coffee output was unchanged on five farms, increased on two farins, 
Table 11. The alternative crops increased first by annual payments for coffee removal

\begin{tabular}{lll}
\hline & $\begin{array}{c}\text { Anriual payment } \\
\text { per manzana }\end{array}$ & Crop increased \\
\hline 1 & $\begin{array}{l}\text { (colones) } \\
2\end{array}$ & \\
2 & $3,000^{a}$ & None \\
3 & 2,900 & Mixed crops \\
4 & 600 & Corn, beans \\
5 & 600 & Corn, beans \\
6 & 1,100 & Beans, sesame \\
7 & 1,100 & Corn, beans, sesame \\
8 & 2,200 & Corn, beans, castorbeans \\
9 & 2,600 & Corn, beans, sesame \\
10 & 1,700 & Sugaicane \\
11 & 500 & Sugarcane \\
12 & 900 & Limes \\
$13 \mathrm{~A}$ & 3,000 & None \\
$13 \mathrm{~B}$ & 400 & Limes \\
$14 \mathrm{~A}$ & 200 & Corn, beans \\
$14 \mathrm{~B}$ & 700 & Limes \\
$15 \mathrm{~A}$ & 900 & Corn, beans \\
$15 \mathrm{~B}$ & 800 & Limes \\
$16 \mathrm{~A}$ & 600 & Corn, beans \\
$16 \mathrm{~B}$ & 3,000 & None \\
& 3,000 & Noneb \\
& &
\end{tabular}

When changes were not initiated by the levels of payment first programmed, additional runs extended the levels of payment.

${ }^{b}$ Land was idled as credit became more limited due to coffee removal. 
Table 12. Comparisons of income and coffee production for differentiated prices versus single prices

\begin{tabular}{|c|c|c|c|c|}
\hline \multirow[b]{2}{*}{ Farm } & \multicolumn{2}{|c|}{ Incomes } & \multicolumn{2}{|c|}{ Coffee } \\
\hline & Single price & Two prices & Single price & Two prices \\
\hline & (colones) & (colones) & (fanegas) & (fanegas) \\
\hline 1 & 19,781 & 19,781 & 82.8 & 82.8 \\
\hline 2 & 18,025 & 17,484 & 193.2 & 193.2 \\
\hline 3 & 35,543 & 45,709 & 750.0 & 750.0 \\
\hline 4 & 31,667 & 26,220 & 225.0 & 192.0 \\
\hline 5 & 16,877 & 16,877 & 190.0 & 190.0 \\
\hline 6 & -760 & $-1,389$ & 76.0 & 71.3 \\
\hline 7 & 7,147 & 6,657 & 62.0 & 57.0 \\
\hline 8 & 4,005 & 3,880 & 19.0 & 17.5 \\
\hline 9 & 86,761 & 86,870 & 997.2 & 997.2 \\
\hline 10 & 29,489 & 32,330 & 213.3 & 225.0 \\
\hline 11 & 24,536 & 24,536 & 100.0 & 100.0 \\
\hline 12 & 7,078 & 7,176 & 22.5 & 22.5 \\
\hline $13 A$ & 89,948 & 96,670 & 195.6 & 650.0 \\
\hline 138 & 67,694 & 70,792 & 900.0 & 650.0 \\
\hline $14 A$ & 24,222 & 24,448 & 18.4 & 18.4 \\
\hline $14 B$ & 16,718 & 17,056 & 70.0 & 60.1 \\
\hline $15 A$ & $5,4: 59$ & 5,975 & 17.4 & 8.2 \\
\hline i 58 & 5,209 & 4,922 & 20.0 & 20.0 \\
\hline $16 \mathrm{~A}$ & 4,307 & 4,350 & 3.0 & 3.0 \\
\hline $16 B$ & 3,612 & 3,586 & 3.0 & 5.6 \\
\hline
\end{tabular}


and reduced on three farms. Of the eight farms with reduced coffee output, five had income reduced below the single price optimum.

When differentiated coffee prices were used to separate sales into new and traditional markets, optimal output was reduced or unchanged on farms where the base used for establishing the traditional market quota was equal to or less than the initial optimal coffee output. However, in those cases where new activities replaced coffee and optimal output fell well below the historical base, then the optimal coffee output increased or was unchanged when prices were differentiated. Income increases were associated wi th above optimal production in the base period. Increased shifts toward lime or vegetable production did not occur when prices were differentiated to reflect different export earnings in new markets and traditional markets.

\section{Reduction of Credit}

The reduction of credit has been suggested as an effective means of controlling coffee output. As Table 13 shows, coffee output is reducible if this measure can be imposed. However, there are effects on farm incomes also (Table 14). In 10 of the 20 farm situations, income was first reduced by credit restrictions without affecting coffee production. In four situations where horticultural crops replaced coffee in the initial solution a reduction in operating credit actually brought increased coffee production within certain levels of constraint. The magnitude of the income reduction is grcater where the optimal solution contained alternative crops. Since credit availability was tied to coffee land in the molel, a credit restriction cut coffec production without encouraging diversification. Coffee land 


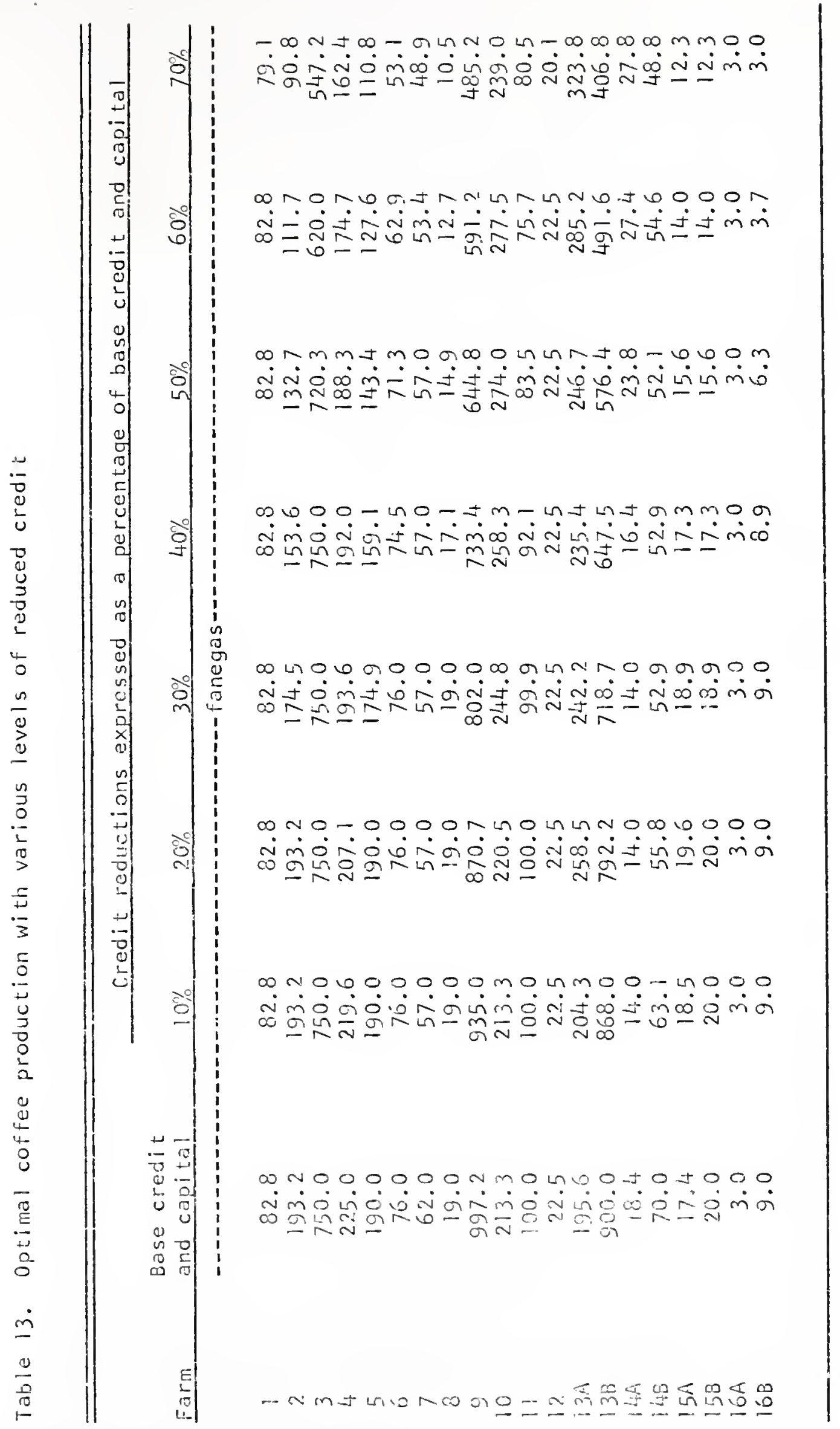




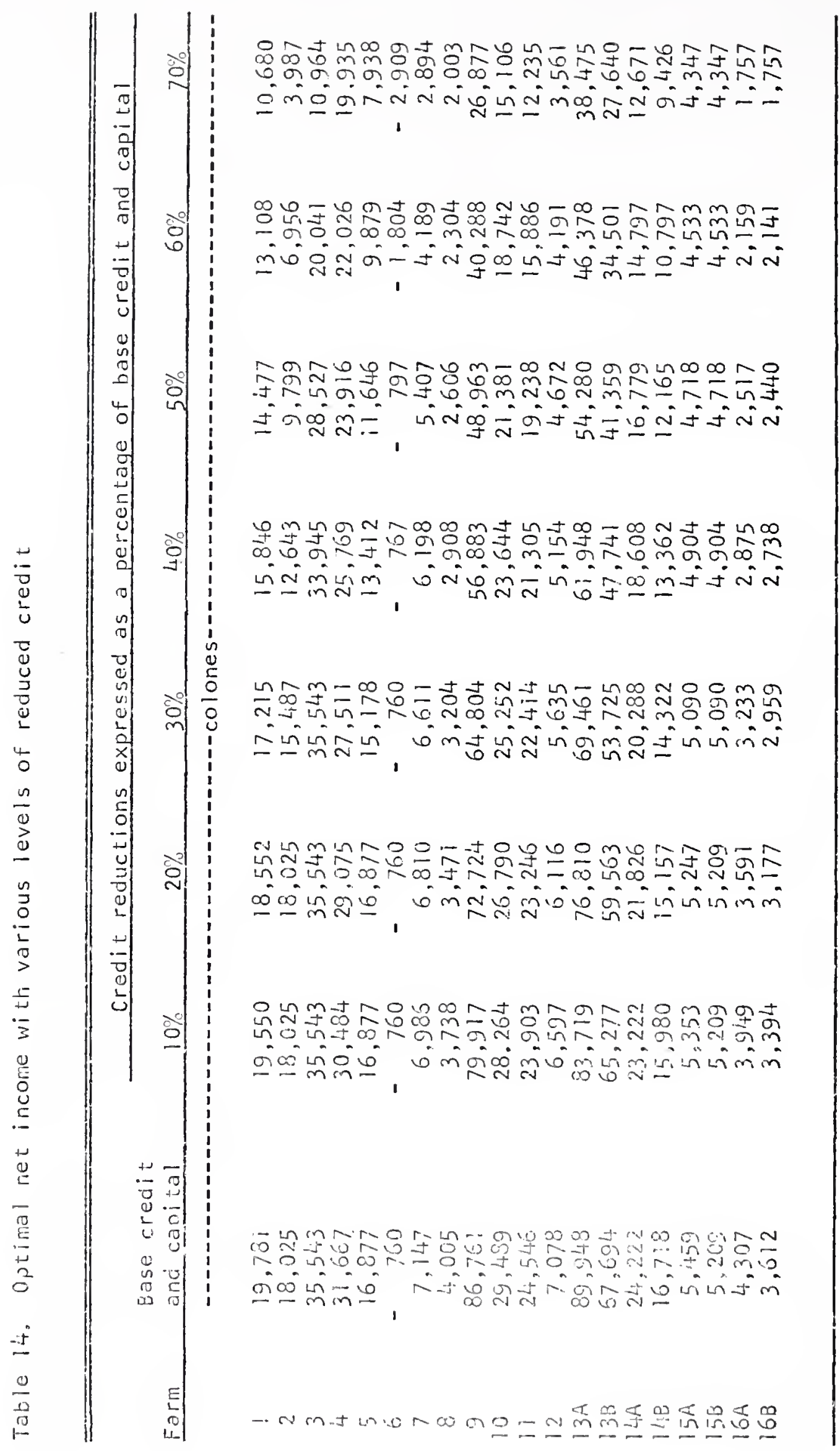


use was reduced only when new plantings occurred in the model. Semiabaridonment of coffee did not use up restricted credit and the stability of land use is stiown in Table 15.

The shadow prices of the credit row are given in Table 16. These showed very high returns to additional credit especially as credit reductions occurred. Before short-term credit effectively reduced coffee production, the marginal returns greatly exceeded the usurious rates of money lenders.

\section{Movement of Labor}

The possibility that a higher demand for off-farm labor could shift resources out of coffee production was considered. Table 17 shows a movement of family workers in 11 of 17 farm situations having family labor. However, coffee output was not changed in 15 of the 17 cases. On farm 10, moving workers would increase optimal coffee production and on farm 138 , the movement brought about a slight decrease in programmed coffee output. Higher family income from new jobs indicated that family workers received less than legal wage rates.

A similar inquiry also indicated that more permanent labor was hired than needed for maximum net returns. The relaxation of labor inflexibility showed that 12 of 20 farms coula increase profits by encouraging employee mobility to other jobs. As shown in Table 18 , coffee production was influenced on only two of 17 farms.

The movement of labor altered farm output on some farms but the effects upon coffee output was negligible. Of the farms studied, the smaller farms have larger percentages of excess labor. This may be necessary to assure ample harvesting iabor on a number of the farms al though motivations oitser than piofit naximization appear to be monifested. 
$0.000000000 \ln 000.00 \mathrm{~m} n$ mí் $00000000000 \ln m 00000 \mathrm{mn}$ ம்ட்

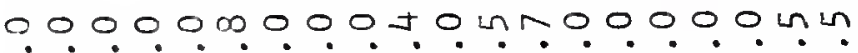

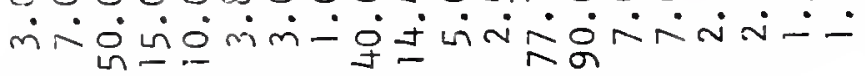

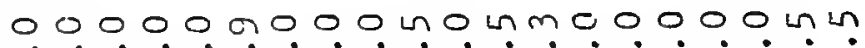

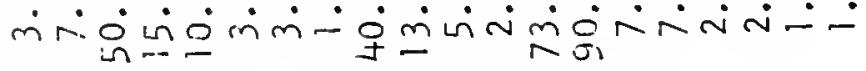

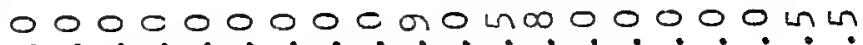

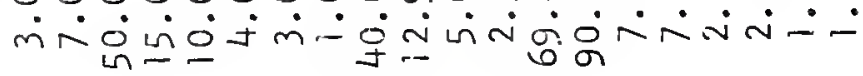

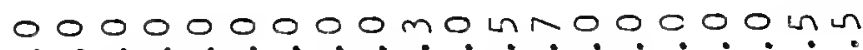

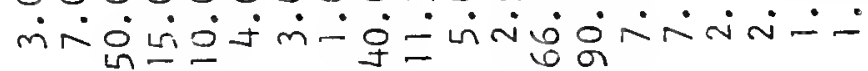

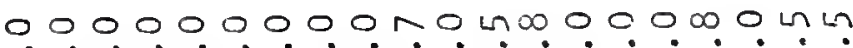

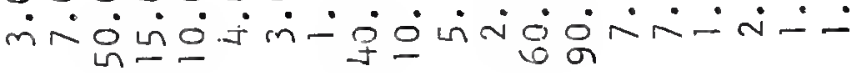

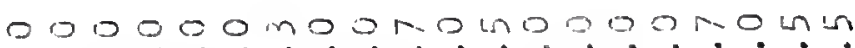

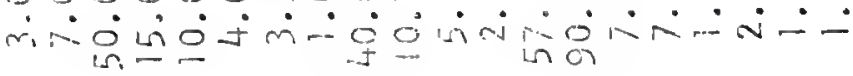




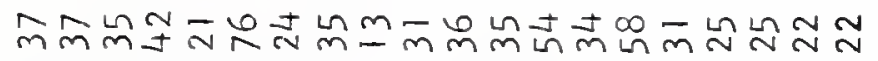

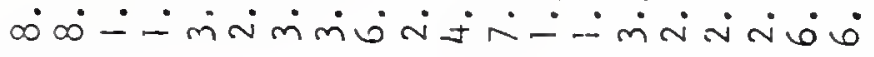

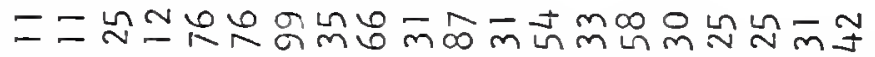

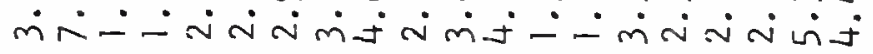

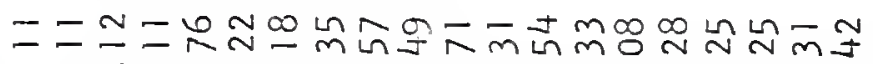

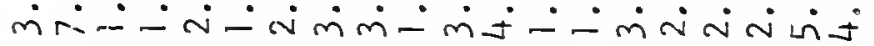

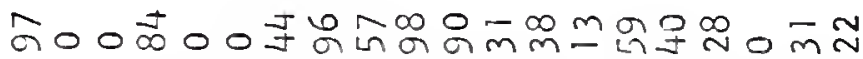
Nं0்ல0ல்

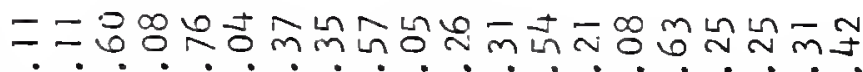

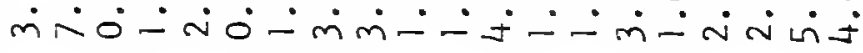

ニニ míó

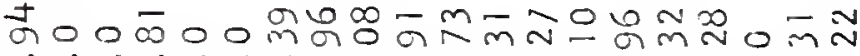

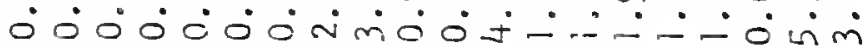

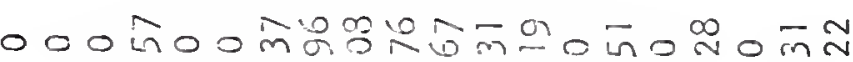

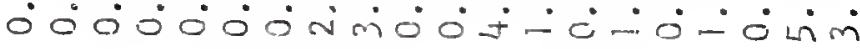




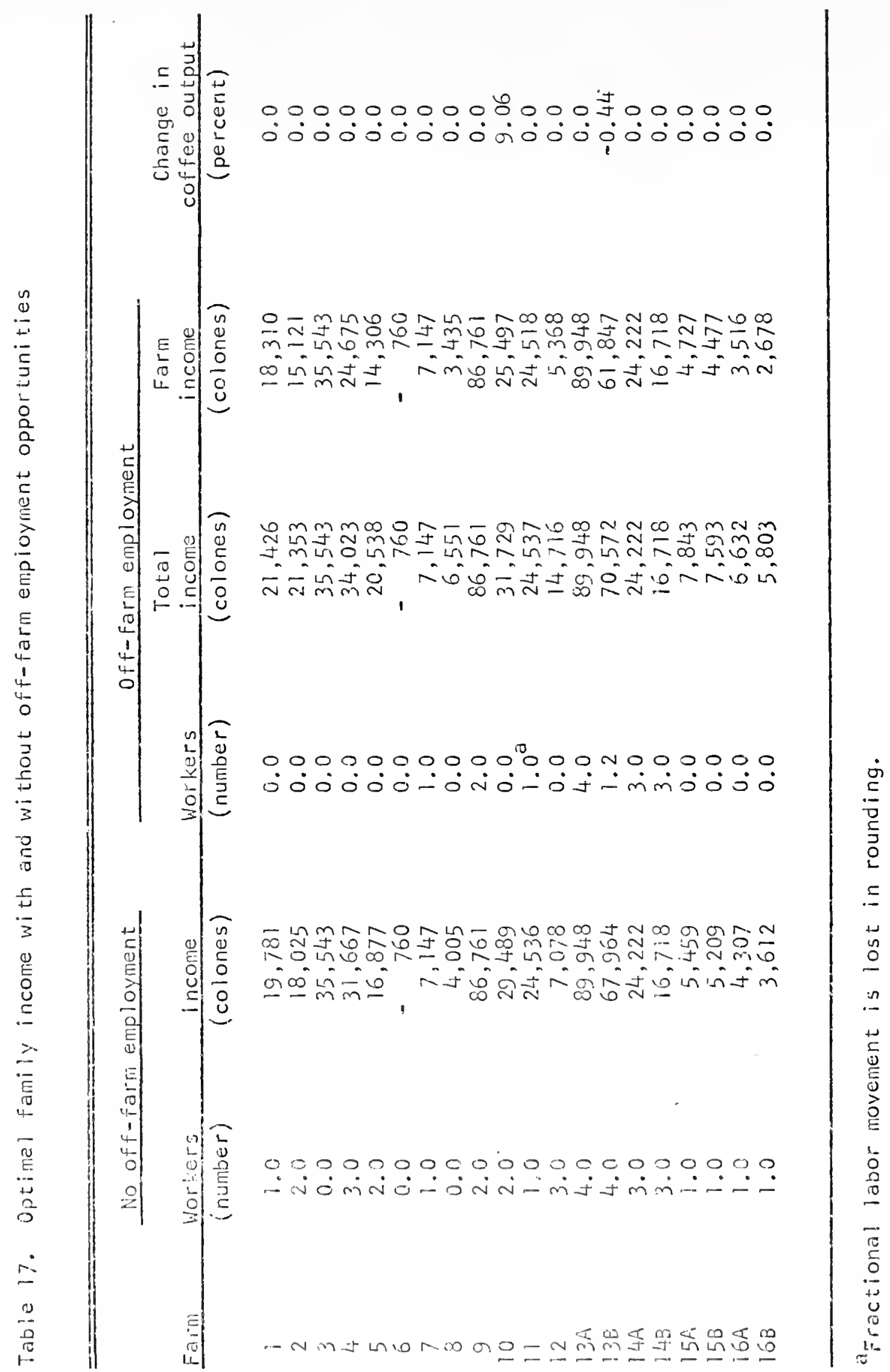




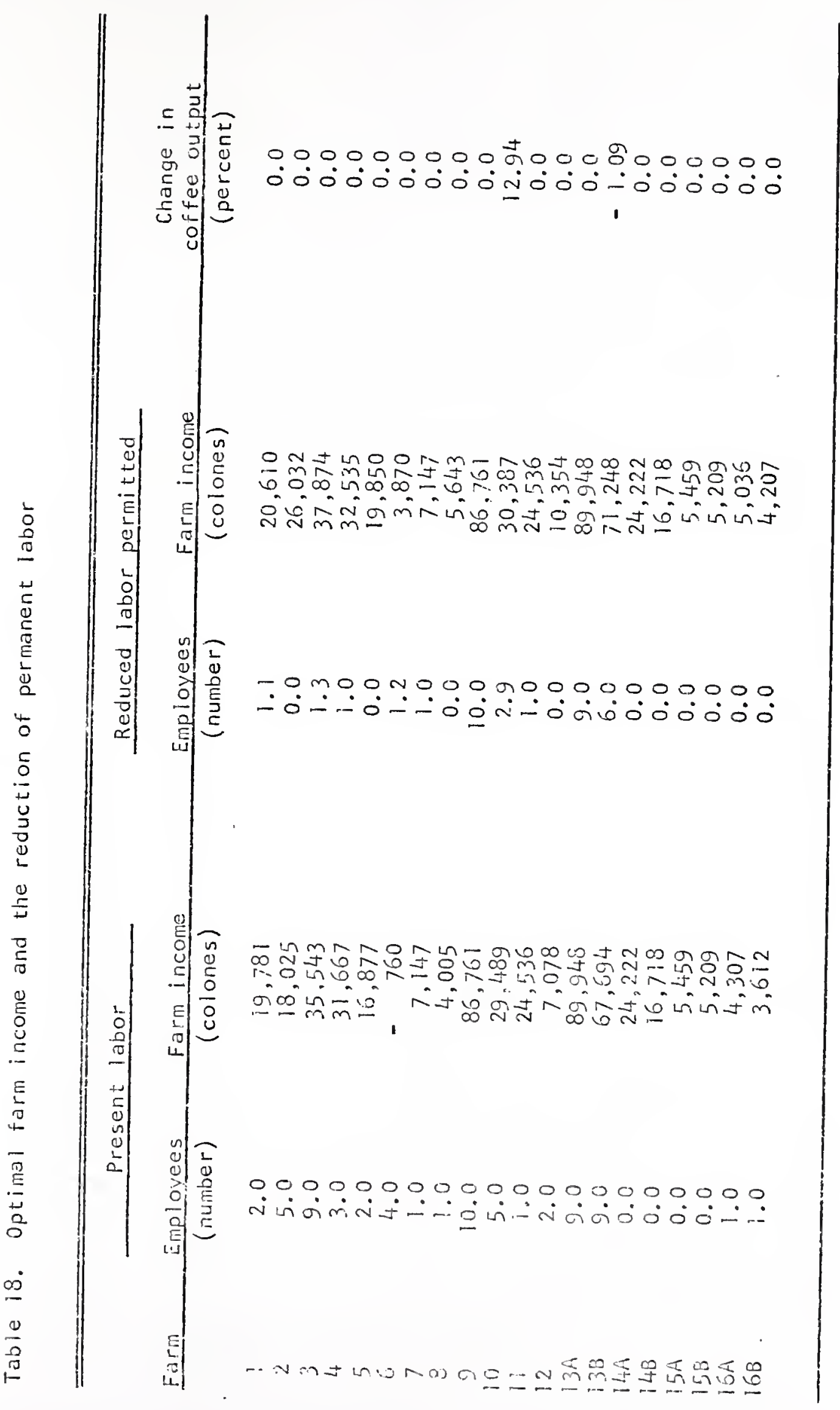




\section{Extra Credit}

Income and coffee output with special credit for crops other than coffee and expanded total credit are shown in Table 19. The poorer farms from Palmares shifted resources into coffee production and expanded coffee output with both special and extra credit. With the special credit, capital formerly used for corn and tobacco was released for coffee.

Programmed extra credit made an additional $\$ 2,000$ per manzana available for annual expenditures. The major difference between the programmed effects of special credit and extra credit was that more money was made available in the latter. The incomes for those farm situations with horticultural crops considered among the diversification alternatives were increased over 10 percent on seven of the eight farms, over 50 pereent on six of eight farms and over 100 percent on four of eight farms.

Increasing the availability of credit increased coffee production in two of the 20 farm situations studied, decreased production in seven cases and jid not affect coffee production in seven casas. In the Palmares and San Ramón situations, programmed increased credit did not cause the alternatives to substitute for coffee. This was also true in the Acosta situations with low fruit prices. Increased credit effectively reduced coffee output in the farm modeis where fruit and vegetable crops offered a higher net return per manzana than coffee. Only on farm 11 did labor supervision restrictions prevent the expansion of horticultural production onto coffee land when unlimited aredit was made available.

As shown in Table 20 the increase in crejit expanded production 


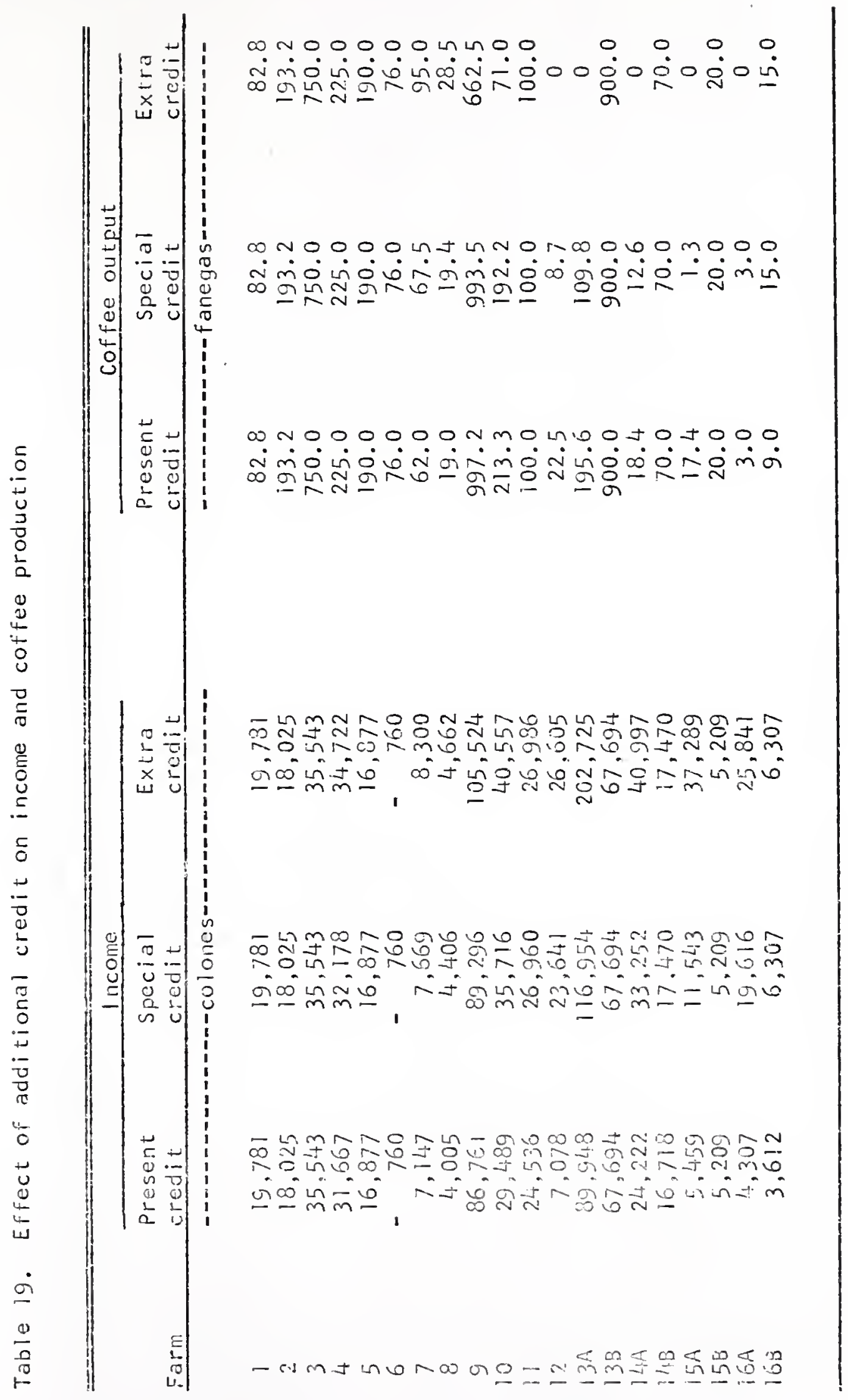




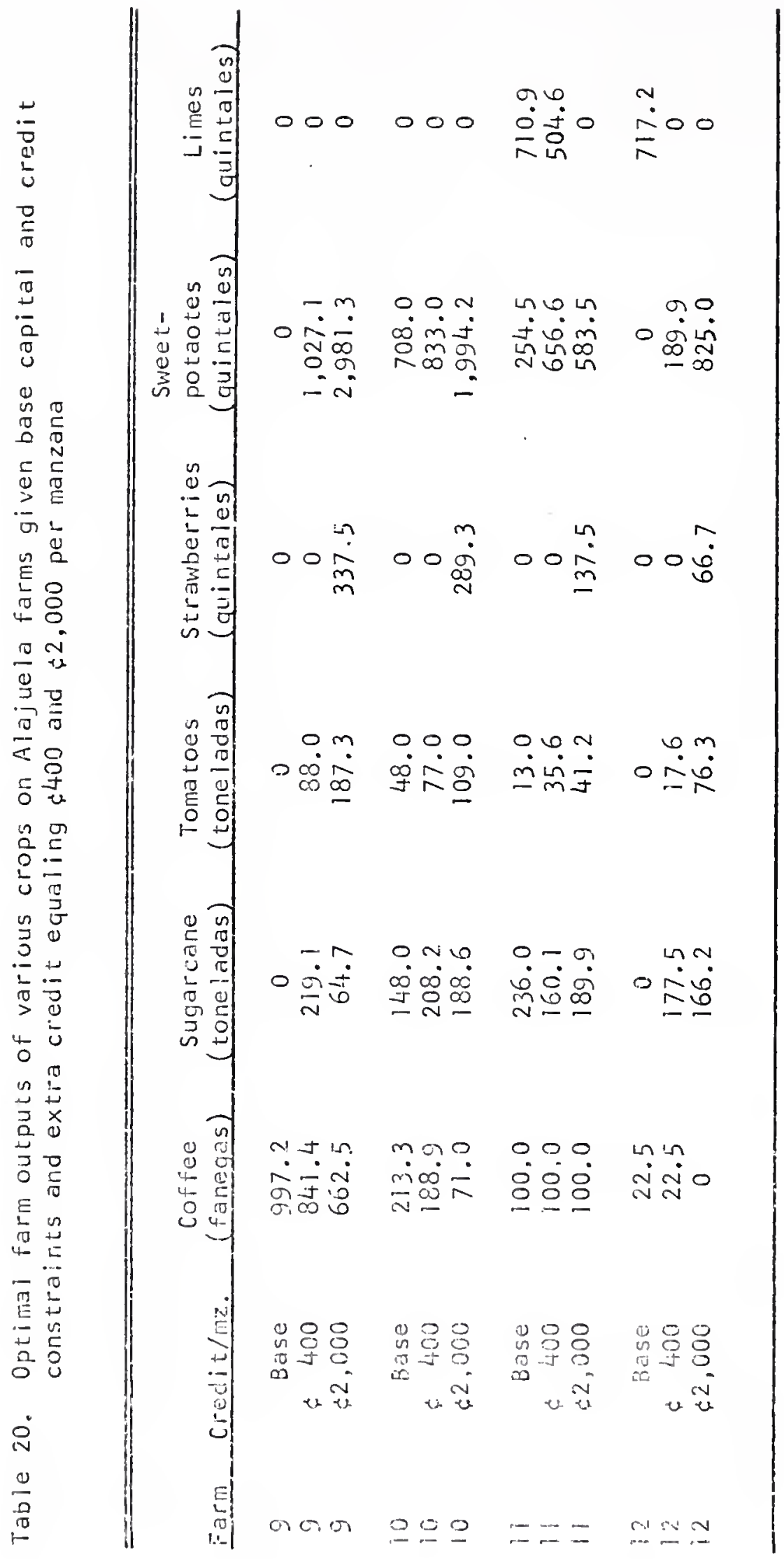


of strawberries, tomatoes and sweetpotatoes on each of the four farms studied from Alajuela. Intermediate effects of lesser increases of credit were an expansion of sugarcane and a decrease in limes. Ups and downs in production occurred with sugarcane and sweetpotatoes as credit was increased. Sugarcane and tomatoes first replaced coffee and then higher increases in credit allowed strawberries and sweetpotatoes to be expanded as labor supervision became a iimiting factor in certain months. This pattern was not the case on farm 11 because a lower labor supervision constraint was programmed. In that case, labor supervision biocked expansion of intensive horticultural crops before coffee output was affected. Those crops giving higher net returns per manzana than coffee required higher levels of labor as weil as more short-run capital than was required for coffee production.

As shown in Tabie 21 , the increase of credit availability also allowed intensive horticultural crops to substitute for coffee. Small increases in credit increased coffee output on the two farms which had the most land not planted to coffee and for which semi-abandoned coffee was part of the initial optimal solution. Coffee output was reduced to zero before labor supervisory restraints blocked the production of blackberries.

\section{Subsidies for Alternatives}

The payment of subsidies for the production of specizic alternatives is also a possible policy measure. In general, results indicated that this was less efficient than disincentives for coffee production when the same resu'ts were obtainable. Subsidies for biackberries or strawberries had no effect on coffee acreage in those situations where part of the farm :as not planted to coffee. Credit limited 
Table 21. Optima! output of various crops on Acosta farms with high iruit prices given base capital and credit and extra credit equaling $\$ 400$ and $\$ 2,000$ per manzana

\begin{tabular}{|c|c|c|c|c|}
\hline Farm & Credit/mz. & $\begin{array}{c}\text { Coffee } \\
\text { (fanegas) }\end{array}$ & $\begin{array}{c}\text { Limes } \\
\text { (quintales) }\end{array}$ & $\begin{array}{l}\text { Blackberries } \\
\text { (quintales) }\end{array}$ \\
\hline $\begin{array}{l}13 A \\
13 A \\
13 A\end{array}$ & $\begin{array}{r}\text { Base } \\
\& \quad 400 \\
\$ 2,000\end{array}$ & $\begin{array}{c}195.6 \\
162.5 \\
0\end{array}$ & $\begin{array}{l}17,780 \\
20,644 \\
36,607\end{array}$ & $\begin{array}{r}0 \\
0 \\
1,402\end{array}$ \\
\hline $\begin{array}{l}14 \mathrm{~A} \\
14 \mathrm{~A} \\
14 \mathrm{~A}\end{array}$ & $\begin{array}{r}\text { Base } \\
\& \quad 400 \\
\& 2,000\end{array}$ & $\begin{array}{c}18.4 \\
22.8 \\
0\end{array}$ & $\begin{array}{l}3,600 \\
4,175 \\
5,695\end{array}$ & $\begin{array}{r}0 \\
0 \\
294\end{array}$ \\
\hline $\begin{array}{l}15 \mathrm{~A} \\
15 \mathrm{~A} \\
15 \mathrm{~A}\end{array}$ & $\begin{array}{r}\text { Ease } \\
\& \quad 400 \\
\& 2,000\end{array}$ & $\begin{array}{l}17.4 \\
6.5 \\
0\end{array}$ & $\begin{array}{l}106 \\
541 \\
463\end{array}$ & $\begin{array}{r}0 \\
0 \\
135\end{array}$ \\
\hline $\begin{array}{l}16 \mathrm{~A} \\
16 \mathrm{~A} \\
15 \mathrm{~A}\end{array}$ & $\begin{array}{r}\text { Base } \\
400 \\
\$ 2,000\end{array}$ & $\begin{array}{l}3.0 \\
7.7 \\
0\end{array}$ & $\begin{array}{r}382 \\
2,292 \\
1,350\end{array}$ & $\begin{array}{r}0 \\
0 \\
500\end{array}$ \\
\hline
\end{tabular}


berry production even when high prices were paid. For Alajuela, higher priced strawberries repiaced tomatoes or limes in the model. Blackberries replaced limes or corn and beans in Acosta as prices were increased. The effect on coffee output was reduced yields as capital was transferred from coffee to berries or increased optimal acreage as credit limited coffee tree removal. Table 22 shows the effect of a blackberry subsidy on coffee output, and Table 23 shows the effect of a straviberry subsidy on coffee output.

With low fruit prices higher berry prices shifted resources from coffee but, with high fruit prices, resources were shifted to berry production from 1 imes and increased coffee output occurred.

\section{Stability of Alternative Crops}

Lime prociuction replaced coffee in two of eight farms when the lime price was programmed at $\$ 13.00$ per quintal. Lime production occurred in the optima! resource use in six of the eight situations. Limes did not replace coffee when other land was available. The instability of lime production in the model wher interest rates were increased indicetes that long-term credit is required at subsidized ratas. As shown in Table 24, no limes would be produced with a 14 percent long-term interest rate. Coffee was not removed when an interest rate of 10 percent was used in the program.

The prices of limes necessary to stimulate lime production in the model are given in Table 25. These pirices ale lower for Acosta farms than for Alajueia farms. The price reguired to stimulate coffee removal is aiso shown. Without extra credit the poorer farms could not replace coffee with limes at any price. A third price column 
Table 22. The effect of a blackberry subsidy on optimal coffee output

\begin{tabular}{|c|c|c|}
\hline \multirow[b]{2}{*}{ Farm } & \multicolumn{2}{|c|}{ Coffee output } \\
\hline & No subsidy & $\begin{array}{l}\text { Subsidy of } \$ 50 \text { per } \\
\text { quintal on blackberries }\end{array}$ \\
\hline & (fànegas) & (fanegas) \\
\hline $13 \mathrm{~A}$ & 195.6 & 240.2 \\
\hline $13 B$ & 900.0 & 900.0 \\
\hline $14 \mathrm{~A}$ & 18.4 & 25.7 \\
\hline $14 B$ & 70.0 & 26.0 \\
\hline $15 \mathrm{~A}$ & 17.4 & 11.1 \\
\hline $15 B$ & 20.0 & 19.5 \\
\hline $16 \mathrm{~A}$ & 3.0 & 3.0 \\
\hline $16 B$ & 9.0 & 9.0 \\
\hline
\end{tabular}

Table 23. The effect of a strawberry subsidy on optimal coffee output

\begin{tabular}{ccc} 
Coffee output \\
\cline { 2 - 3 } Farm & $\begin{array}{c}\text { No subsidy of cl00 per } \\
\text { cuintal of strawberries }\end{array}$ \\
\hline & (fanegas) & (fanegas) \\
10 & 997.2 & 997.2 \\
11 & 213.3 & 158.4 \\
12 & 100.0 & 89.6 \\
22.5 & 22.5
\end{tabular}


Table 24. Relationships between long-term interest rates and manzanas planted to limes

\section{Interest rate in percent}

\begin{tabular}{llllll} 
Farm & 6 & 8 & 10 & 12 & 14 \\
\hline 9 & 0.0 & 0.0 & 0.0 & 0.0 & 0.0 \\
10 & 0.0 & 0.0 & 0.0 & 0.0 & 0.0 \\
11 & 1.78 & 1.52 & 0.0 & 0.0 & 0.0 \\
12 & 1.79 & 0.0 & 0.0 & 0.0 & 0.0 \\
$13 \mathrm{~A}$ & 44.45 & 16.44 & 11.50 & 11.50 & 0.0 \\
$14 \mathrm{~A}$ & 9.00 & 9.00 & 8.11 & 4.14 & 0.0 \\
$15 \mathrm{~A}$ & 0.26 & 0.0 & 0.0 & 0.0 & 0.0 \\
$16 \mathrm{~A}$ & 0.96 & 0.96 & 0.60 & 0.60 & 0.0 \\
\hline
\end{tabular}


Table 25. Lime prices and lime production

Minimum price of limes per quintal

\begin{tabular}{lccc}
\hline & $\begin{array}{c}\text { For production } \\
\text { on any land }\end{array}$ & $\begin{array}{c}\text { For production } \\
\text { on coffee land }\end{array}$ & $\begin{array}{c}\text { For a } 25 \% \text { increase } \\
\text { in net returns }\end{array}$ \\
\hline 9 & 19.37 & 19.37 & 23.40 \\
10 & 14.45 & 14.45 & 16.27 \\
11 & 12.05 & 14.80 & 15.34 \\
12 & 12.90 & 11.81 & 15.34 \\
13 & 9.73 & 14.56 & 12.70 \\
14 & 10.31 & 10.64 & 12.08 \\
15 & 10.64 & a & 14.18 \\
16 & 10.63 & & 13.54
\end{tabular}

${ }^{a}$ Credit restrictions prevent planting coffee 1 and to lines regardless of price. 
gives the price necessary to increase farm net returns by 25 percent. This arbitrary level was chosen to illustrate that a difference may exist between changes that maximize net returns and changes that are significant enough to motivate action in the face of risk. These prices may be further modified by calculations to offset changes in the interest rate. Since the long-term investment is valued at $\$ 15,000$ per manzana and the yield is 400 quintales of 1 imes per manzana, each 1 percent increase in the rate of long-term interest would require the price of limes to be increased $\$ 0.375$ per quintal. Thus, if a price of $\$ 12.00$ must be paid to stimulate lime production given a 6 percent interest rate, the price must be increased to $\$ 13.50$ per quintal if the same production is to occur with a 10 percent interest rate.

Limes compete well with lower-yielding coffee but the costs of production would be less on non-coffee land.

In Alajuela sweetpotatoes, peppers and tomatoes were priced at moderately high levels for prosessor lise under the assumption that production would be on a contract basis for the Central American Common Market. The price estimates used were programmed downward to test the stability of the production of tomatoes and sweetpotatoes in the optimal solutions.

A 25 percent decrease in vegetable prices was accompanied by a shift to sugarcane, stravberry and peanut production on farm 10. Coffee acreage was reduced and sugarcane projuction was doubled. Output was comprised of 179.1 faregas of coffee, 151.2 quintales of strawberries, 16.2 quintaies of pearuts, 362.8 tcns of sugarsane and 119.5 quintaies of sweetpotatues. A 36 persent decline in vegetable 
prices blocked sweetpotato production. Strawberry output increased to 154.0 quintales and coffee output fell to 176.8 fanegas. Corn production replaced part of the sweetpotatoes. Sales included 38.3 quintales of corn, 16.1 quintales of peanuts and 369.7 tons of sugarcane. These parametric changes showed that strawberries may be a likely alternative despite their failure to appear in the optimal solution.

On farm 11, strawberries, peanuts and limes replaced sweetpotatoes and tomatoes when the prices of vegetables were programmed downward. With a 25 percent price decline for vegetables, the programmed output was 100.0 fanegas of coffee, 1.0 quintal of beans, 954.4 quintales of limes, 77.8 quintales of strawberries, 1.8 quintales of peanuts, 186.8 tons of sugarcane and 100.0 quintales of sweetpotatoes. With a further price decline to 50 percent of the vegetabie prices, corn replaced sweetpotatoes. The programmed output was 100.0 fanegas of coffee, 25.0 quintales of corn, 887.1 quintales of limes, 82.1 quintales of strawberries, 7.6 quintales of peanuts and 196.9 tons of sugarcane. Income was reduced from $\$ 24,536$ to $\$ 23,282$ when the vegetable crops were excluded from the model.

Increases in orange prices resulted in oranges first substituting for limes and only affecting coffee production on tine Alajuela and Acosta farms after other land was utilized. The orange enterprise was less competitive than limes, but if prices were stable atove só per hundred, part of the resources could be rationally diverted from coffee to oranges.

Minimum prices that encourage orange production are shown in Table 25. The pricss for orange production were calculated by adding 
Table 26. Prices of oranges necessary to initiate orange production on farms in Alajuela and Acosta

\section{Orange price per hundred}

Farm For orange production For coffee substitution (colones) (colones) 9 7.24 5.82

7.24

10

11

12

$13 \mathrm{~A}$

5.25

4.57

5.10

$13 B$

4.11

5.02

$14 B$

4.08

5.82

$15 \mathrm{~A}$

$15 B$

$16 \mathrm{~A}$

5.17

4.50

$16 \mathrm{~B}$

4.38

5.99

6.27

5.63

4.25

5.13

5.07

5.68

4.50

3.18

a

${ }^{a}$ Credit restriction blocks orange planting on coffee land regardless of price. 
the parametric change to the initial price when an iteration brought oranges into the solution. The prices for coffee removal represent the price at the first iteration where either the coffee tree destruction activity entered the basis or a coffee production activity left the basis. Overestimation of price needed to initiate coffee removal could have cccurred on those farms where coffee trees were removed in the initial optimal solution since a print-out was not called at every iteration.

The comparative profitability between oranges and limes are close enough to raise doubts as to the superiority of limes over cranges.

\section{Comparative Costs of Coffee Removal}

One means of evaluating the efficiency of various policy measures is to caiculate the costs of removing one fanega of coffee. The base for comparisons is the farm price of coffee which estimates the costs of burning harvested coffee. The comparative costs are derived by dividing the reduction of income by the number of fanegas reduced.

Tables 27 through 34 show comparative costs for various methods of reducing coffee output on farms in the Palmares-san pamón area. Higher costs for diversification were associated with higher coffee yields and greater reductions in coffee output. Even on farms 1 and 2. the costs of reducing coifee output were reduced if the released resources were puit to alternative use. The cheapest means of reducing cutput was blocking new plantings but little outplit was affected. Credic reduction was not efficient since non-cofree crops were affected. Shifting non-land resources from coffee to alternative crops froduced 
Table 27. Alternative methods of reducing coffee output on farm 1

Coffee reduction

Method

Burning coffee

Credit reduction $(70 \%)$

Mandatory abandonment ${ }^{a}$

Mandatory semi-abandonment ${ }^{a}$

Mandatory traditional output ${ }^{a}$

Tree removal and diversification

Tree removal and diversification
Cost per fánega

$\therefore 203.31$

$2,446.40$

158.72

155.06

154.37

115.30

120.63
Fanegas

Percent

$82.8 \quad 100.0$

3.7

4.5

27.6

33.3

23.6

28.5

18.6

22.5

5.0

6.0

10.0

12.1

acosts were calculated with one manzana shifted to less-intensive production as other production was held constant. 
Table 28. Comparative costs of various methods of coffee output reduction on farm 2

\section{Coffee reduction}

Me thod

Credit reduction (25\%)

Credit reduction $(30 \%)$

Credit reduction $(50 \%)$

Credit reduction (70\%)

Burning coffee

Mandatory abandonment ${ }^{a}$

Mandatory semi-abandonment ${ }^{a}$

Mandatory traditional output ${ }^{a}$

Tree removal and diversification

Tree removal and diversification

Tree removal and diversification
Cost per fanega

Fanegas

Percent

$\$ 135.86$

8. 2

4.2

135.86

18.7

9.7

135.86

60.5

31.3

137.08

102.4

53.0

203.31

193.2

100.0

137.22

27.6

14.3

135.86

23.6

12.2

135.95

18.6

9.6

91.02

10.0

5.2

91.02

20.0

10.4

91.02

40.0

20.7

${ }^{a}$ Calculated by shifting one manzana of coffee to less-productive use holding other production coristant. 
Table 29. Alternative methods of reducing coffee output on farm 3

Coffee reduction

\begin{tabular}{|c|c|c|c|}
\hline Method & Cost per fanega & Fanegas & Percen \\
\hline Reduced credit $(50 \%)$ & $\xi 236.22$ & 29.7 & 4.0 \\
\hline Reduced credit $(60 \%)$ & 119.24 & 130.0 & 17.3 \\
\hline Burning coffee & 203.31 & 750.0 & 100.0 \\
\hline Mandatory abandonment ${ }^{a}$ & 101.62 & 15.0 & 2.0 \\
\hline Mardatory semi-abandonment ${ }^{a}$ & 92.37 & 11.0 & 1.4 \\
\hline Mandatory traditional output ${ }^{\exists}$ & 59.80 & 6.0 & 0.8 \\
\hline Tree removal and diversification & 36.36 & 80.8 & 10.8 \\
\hline Tree removal and diversification & 37.12 & 86.1 & 11.5 \\
\hline Tree removal and diversification & 47.48 & 287.2 & 38.3 \\
\hline Tree removal and diversification & 51.84 & 485.8 & 64.8 \\
\hline
\end{tabular}

${ }^{a}$ Calculated by shifting one manzana of coffee to $\exists$ less-froductive use holding cther production constant. 
Table 30. Aiternative me thods of reducing coffee cutput on farm 4

Coffee reduction

Method

Cost per fanega

Fanegas

Percent

Reduced credit $(10 \%)$

$\$ 220.52$

5.4

2.4

Reduced credit $(30 \%)$

132.50

31.4

14.0

Reduced credit $(60 \%)$

191.80

50.3

22.4

Reduced credit $(90 \%)$

180.42

94.0

41.8

Burning coffee

203.31

225.0

100.0

Mandatory abandonment ${ }^{a}$

109.35

15.0

6.7

Mandatory semi-abandonment ${ }^{a}$

103.10

11.0

4.9

Mandatory traditional output ${ }^{2}$

112.38

6.0

2.6

Shifting operating capital

16.32

2.9

1.3

Shifting operating capital

27.06

33.0

14.7

Shifting operating capital

37.96

68.4

30.4

Tree removal

37.64

3.6

1.6

Tree removal

40.28

4.1

1.8

Tree removal

60.24

33.0

14.7

Trce removal

68.23

56.2

25.0

Tree removal

94.90

225.0

100.0

Price difierentiation

164.75

33.0

14.7

${ }^{a}$ Calculated by shiftirig one manzana of coffee to less-productive use holding other production constant. 
Table 31. Comparative costs of various methods of reducing coffee output on farm 5

Coffee reduction

\begin{tabular}{|c|c|c|c|}
\hline Me thod & Cost per fanega & Faneqas & Percent \\
\hline Burning coffee & $\$ 203.31$ & 190.0 & 100.0 \\
\hline Credit reduction $(25 \%)$ & 112.21 & 7.3 & 3.8 \\
\hline Credit reduction $(50 \%)$ & 112.21 & +6.6 & 24.5 \\
\hline Credit reduction $(70 \%)$ & 112.83 & 79.2 & 41.7 \\
\hline Credit reduction $(90 \%)$ & 115.69 & 118.9 & 62.6 \\
\hline Mandatory abandonment ${ }^{a}$ & 127.24 & 19.0 & 10.0 \\
\hline Mandatory sem:-abandonment ${ }^{a}$ & 120.03 & 15.0 & 7.9 \\
\hline Mandatory traditional output ${ }^{a}$ & 112.21 & 10.0 & 5.3 \\
\hline Tree removal and diversification & 57.81 & 2.3 .5 & 12.4 \\
\hline Tree removal and diversification & 60.72 & 42.4 & 22.3 \\
\hline Tree removal and diversification & 61.55 & 47.3 & 24.9 \\
\hline Tree removal and diversification & 66.19 & 59.6 & 29.9 \\
\hline Tree removal and diversification & 72.04 & 77.6 & 40.8 \\
\hline Tree removal and diversification & 75.51 & 110.8 & 58.3 \\
\hline Tree removal and diversification & 79.71 & 142.0 & 74.7 \\
\hline
\end{tabular}

${ }^{a}$ Calculated by shifting one manzana of coffee to a less-productive use while holding other production constant. 
Table 32. Comparative costs of various methods of reducing coffee output on farm 6

Coffee reduction

Me thod

Burning coffee

Credit reduction $(50 \%)$

Credit reduction $(60 \%)$

Credit reduction $(70 \%)$

Credit reduction $(80 \%)$

Credit reduction ( $90 \%)$

Mandatory abandonment ${ }^{a}$

Māndatory semi-abaridonment ${ }^{a}$

Mandatory traditional output

No new planting

Tree removal and diversification

Tree removal and diversification
Cost per fanega

Faneaas

$76.0 \quad 100.0$

६203.31

7.62

4.7

6.2

79.96

13.1

17.2

93.82

23.0

30.2

99.35

32.7

43.0

102.72

42.9

56.4

126.93

19.0

25.0

119.49

15.0

19.7

112.21

10.0

13.2

4.13

4.7

6.2

49.94

32.4

42.5

57.19

76.0

100.0

${ }^{a}$ Calculated by shifting one manzana of coffee to a lower-yielding use holding other production constant. 
Table 33. Comparative costs of various methods of reducing coffee output on farm 7

Coffee reduction

Method

Burning coffee

Credit reduction (5\%)

Credit reduction (55\%)

Credit reduction $(60 \%)$

Credit reduction ( $70 \%)$

Credit reduction ( $75 \%$ )

Mandatory abandonment

Mandatory semi-äbandonment ${ }^{a}$

Maridatory traditional output ${ }^{a}$

No new planting

Diversification of non-land resources

Tree removal and diversification

Tree removal and diversification

Tree remova! and diversification
Cost per fanega Fanegas

Percent

६203.31

62.0

100.0

15.83

5.0

8.1

399.74

5.8

9.4

341.10

8.7

13.1

325.08

13.1

21.1

266.70

18.6

30.0

118.13

19.0

30.6

117.64

15.0

24.1

197.73

10.0

16.1

0.46

5.0

8.1

63.70

16.2

2.6 .1

93.88

38.1

61.4

95.47

40.2

54.8

105.59

62.0

100.0

${ }^{a}$ Calculated by shifting one manzana of coffee to less-productive use holding other production constant. 
Table 34. Comparative costs of various methods of reducing coffee output on farm 8

Coffee reduction

Me thod

Burning coffee

Credit reduction (35\%)

Credit reduction $(50 \%)$

Credit reduction $(60 \%)$

Credit reduction (75\%)

Credit reduction (100\%)

Tree renoval

Mardatory abandonment ${ }^{a}$

Mandatory semi-abaridonment ${ }^{a}$

Mandatory traditional output ${ }^{a}$

Diversification of capital use

Diversification of capital use

Price differentiation
Cost per fanega

$\$ 203.31$

$1,183.43$

339.40

234.15

222.93

265.02

135.59

151.24

143.49

136.21

15.39

60.72

80.71
Fanegas

Percent

19.0

100.0

0.8

4.2

4.1

21.6

8.5

44.7

9.7

51.1

15.0

78.9

19.0

100.0

19.0

100.0

15.0

78.9

10.0

52.6

1.5

7.9

5.0

26.3

1.5

7.9

${ }^{a}$ Calculated by shifiing one manzana of coffee to a less-productive use holding other production constant. 
low cost reductions in coffee output. Direct output control was cheaper than credit reduction on all farms. If coffee trees were removed, then the cost per fanega of reduced coffee output could be lessened 25 to 65 percent by shifting resources into aiternative uses. The shifting of non-land resources was a cheap way of reducing coffee output when excess tobacco allotment was available.

In Alajuela the costs of coffee removal were highest for the smallest farm where the credit restriction blocked the use of higheryielding alternative crops. Normally, the cost per fanega of reduced coffee output was ircreased as larger quantities of coffee were taken out of production. However, in the cases where subsidy payments for other crops first shifted resources from the production of a noncoffee crop to the subsidized crop, the average cost per fanega of coffee removal was higher when only a small percentage of the coffee output was affected. Subsidy payments were expensive means of coffee reduction since non-coffee land was first planted to the subsidized crop. Credit reduction affected the output of other crops before it affected coffee on farms 10 , il and 12.

Tables 35 through 38 show comparative costs of removing one fanega of coffee through various methods on the Alajuela farms. Since print-outs were not called for at every iteration of parametric change, only part of the levels of change ara given. Nevertheless, the comparative costs indicate that the cheapest method of controlling coffee output: would be carried out with resource reallocation afier some direct control of output. Ar annual subsidy for coffee tree removal gives slightly higher removal costs or, two of the farms which indicates thet other factors are more easily shifted out of coffee 
Table 35. The comparative costs of various methods of reducing coffee output on farm 9

Coffee reduction

Me thod

Cost per fanega

Fanegas

Percent.

Burning coffee

Credit reduction ( $10 \%)$

Credit reduction ( $20 \%)$

$\$ 196.73$

997.2

100.0

109.96

62.2

6.2

Credit recuction $(30 \%)$

110.92

126.6

12.7

112.49

195.2

19.6

Credit reduction ( $50 \%)$

113.69

332.5

33.3

Credit reduction (70\%)

116.96

512.0

51.3

Subsidize oranges ( $\$ 3.98 / 100)$

99.01

Subsidize limes ( $\$ 6.37 / q q$.

63.46

709.5

71.2

Subsidize limes (द7.95/qq.)

67.26

259.9

26.1

Coffee tree removal

43.54

Coffee tree removal

43.91

666.6

66.8

51.92

171.5

17.2

Coffee tree removal

67.00

180.7

18.1

Coffee tree removal

117.90

309.7

454.8

31.1

Mandatory abandoment

Mandatory semi-abansonment

114.63

25.0

45.6

119.52

21.0

2.5

16.0

2.1

43.39

Resource reallocation

43.67

176.2

1.6

Resource rea!location

49.51

Resource reallocation

54.31

183.9

17.7

18.4

317.2

31.8

Resource reallccation

452.0

45.3

${ }^{a}$ Calculated by shifting one manzana from highest technology to $\bar{a}$

lower level of output holding other production constant. 
Table 36. The comparative costs of various methods of reducing coffee output on farm 10

Coffee reduction

Cost per fanega

Fanegas Percent

\section{Burning coffee}

Mandatory abandonment ${ }^{a}$

Mandatory semi-abendonmerit ${ }^{a}$

Mandatory traditional output ${ }^{a}$

Subsidize pineapples ( $6114.91 /$ T.)

Subsidize pineapples ( $\left(156.45 / T_{\text {. }}\right.$ )

Subsidize oranges $(c 1.96 / 100)$

Subsidize oranges $(\xi 4.98 /: 00)$

Subsidize strawberries ( $\$ 36.22 / 99$.

Subsidize strawberries ( $\$ 55.55 / q 9$. )

Subsidize strawberries ( $697.74 / q q$.

Subsidize limes (cl.87/qq.)

Subsic'ize limes (63.85/q9.)

Coffee tree removal ( $\$ 572 / \mathrm{mz}$.)

Coffee iree removal ( $\zeta 789 / \mathrm{mz}$.)

Coffee tree removal ( $\zeta 879 / \mathrm{mz}$.)

Coffee tree removal ( $1,588 / \mathrm{mz}$.)

Rescurce reailocation

Resource reallocation

Resource realiocation

Resource reallocation

Resource reallocation
$\$ 196.73$

114.77

114.02

115.55

181.15

311.63

121.69

159.53

71.64

67.65

63.52

46.93

57.58

24.03

31.84

36.77

38.34

23.23

24.03

36.61

40.41

46.70
213.3

20.0

16.0

11.0

17.9

58.6

141.3

213.3

26.8

32.9

55.0

141.3

213.3

26.1

71.3

141.3

149.5

15.7

26.1

141.3

171.0

192.1
100.0

9.4

7.5

5.2

8.4

27.5

66.2

100.0

12.6

15.4

25.8

66.2

100.0

12.2

33.4

66.2

70.1

7.4

12.2

66.2

80.2

90.1

${ }^{a}$ Calculated by shifting one manzana of coffee to a less-productive use holding other production constant. 
Table 37. The comparative costs of various methods of reducing coffee output on farm 11

Coffee reduction

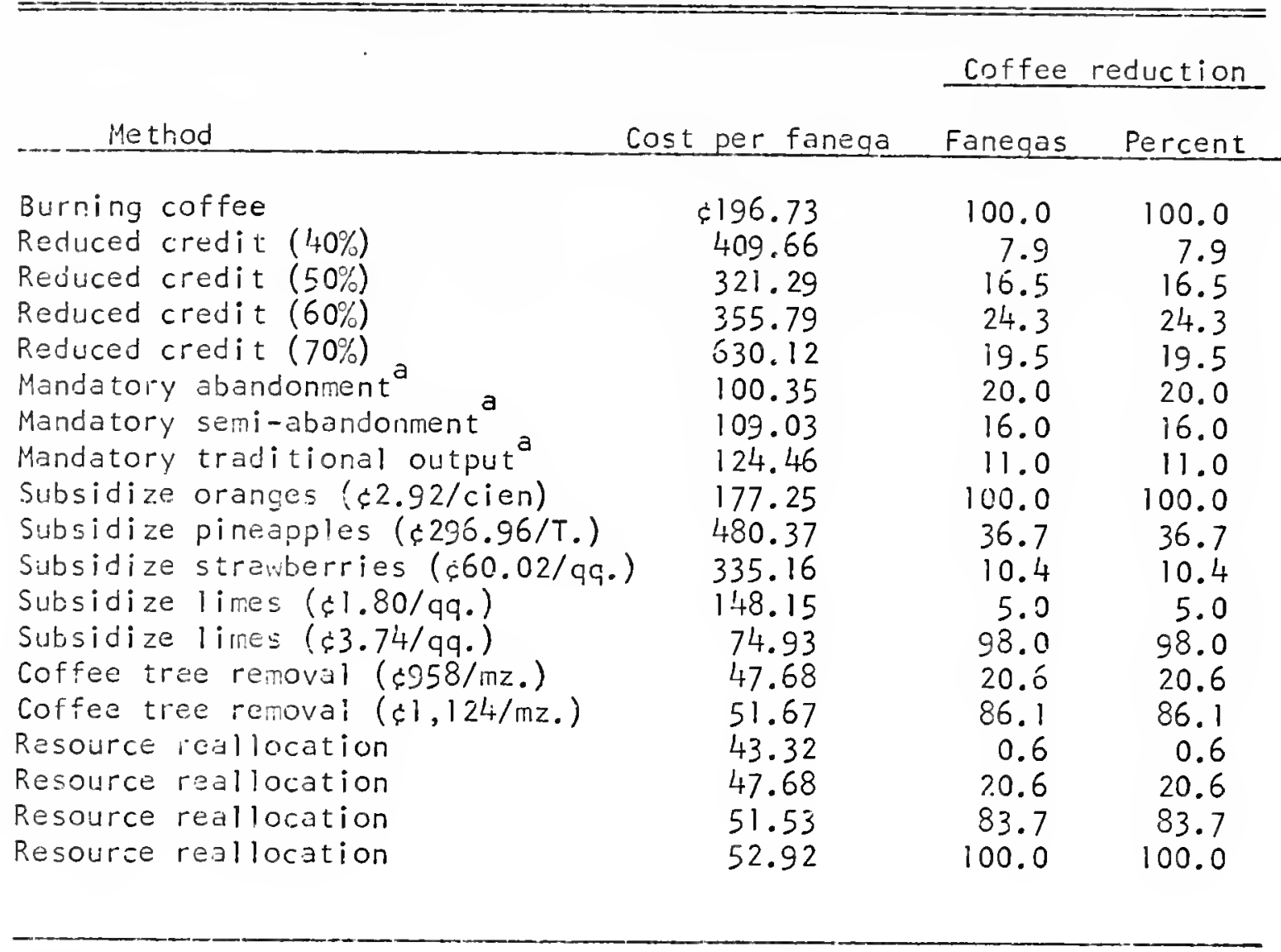

Caiculated by shifting one manzana of coffee to a less-productive use holding other production constant. 
Table 38. The comparative costs of various methods of reducing coffee output on farm 12

Coffee reduction

Method

Burning coffee

Credit reduction $(70 \%)$

Subsidize oranges ( $\$ 1.93 / 100)$

Subsidize 1 imes (\$3.10/99.)

Coffee tree removal $(\xi 3,231.95 / \mathrm{mz}) \quad 359.11$

Mandatory abaridonment ${ }^{a}$

Mandatory semi-abandorment ${ }^{a}$

Resource reallocation
Cost per fanega

$\$ 196.73$

$1,478.38$

$1,735.24$

62.60

137.37

127.48

62.60

12.5

5.0

22.2

55.6

${ }^{a}$ Calculated by shifting one manzana of coffee to less-productive use holding other production constant. 
production than is land. As in the Palmares-San Ramón area the larger reductions in output are generally associated with higher costs.

On the Acosta farms studied the initial optimal coffee production was much lower when high fruit prices were used than when low fruit prices were used. As a result, the responses to parametric changes and comparative costs of reducing coffee output from the initial optimal production also differed.

When high fruit prices were used, coffee trees were removed in the two farm situations where other land was not available. When other land was available, coffee yields were reduced as nor-land resources were shifted from coffee to limes.

Comparative costs of reducing coffee output on the Acosta farms are given in Tables 39 through 42. These costs represent the costs of reducing the initial programmed optimal coffee output and not the output reported for the farms under current practices. Lover costs for coffee removal on farm 13 reflected greater ease in shifting to limes because credit was not as restricted as in the other farm situations. Credit restrictions limited the ability of farm 16 to respond with alternative crops when price or other incentives en.. couraged the reduction of coffee output.

When low fruit prices were used to represent the alternative relationships without local processing in the ficosta area, the prodidotion of coffee approxinated the reported production on the farms studied. With the lowel fruit prices, the initial optimal ontput of coffee was higher than when high fruit prices were used. The comparative costs per fanega of coffee output reduction is given for various policy measures in reteles 43 through Lif. The cheapest method of 
Table 39. The comparative costs of various methods of reducing coffee output on farm 13, given high fruit prices

Coffee reduction

Me thod

Burning coffee

Mandatory abandonment ${ }^{a}$

Mandatory semi-abandonment ${ }^{a}$

Subsidize limes ( $\$ 1.71 / q q$.

Subsidize limes ( $\$ 4.48 / 99$. )

Coffee tree removal ( $\$ 382.60 / \mathrm{mz}$.)

Coffee tree removal (\$684.61/mz.)

Coffee tree removai ( $\$ 1,260.34 / \mathrm{mz}$.)

Resource reallocation

Resource reallocation
Cost per fanega

$\xi 215.20$

111.37

110.35

19.67

24.86

14.37

19.67

24.86

14.37

21.60
Fanegas

195.6

100.0

6.0

3.1

4.0

2.0

66.7

34.1

88.8

45.4

62.5

32.0

$66.7 \quad 34.1$

$88.8 \quad 45.4$

62.5

32.0

87.7

44.8

${ }^{a}$ Calculated by shifting one manzana of the best coffee to lessproductive use holiing other production constant. 
Table 40. The comparative costs of various methods of reducing coffee output on farm 14, given high fruit prices

Coffee reduction

\begin{tabular}{|c|c|c|c|}
\hline Method & st per fanega & Fanegas & Percent \\
\hline Burning coffee & $\$ 215.20$ & 18.4 & 100.0 \\
\hline Subsidize oranges (cl.91/qq.) & $1,492.11$ & 8.6 & 46.7 \\
\hline Subsidize limes (\$2.39/qq.) & 43.55 & 5.0 & 27.2 \\
\hline Subsidize blackberries ( $\$ 20.53 / q q$. ) & 50.41 & 4.4 & 23.9 \\
\hline Mandatory abandonment ${ }^{a}$ & 131.97 & 6.0 & 32.6 \\
\hline Mandatory semi-abandonment ${ }^{a}$ & 131.95 & 4.0 & 21.7 \\
\hline Mandatory abandorment ${ }^{b}$ & 145.00 & 2.0 & 10.9 \\
\hline Coffee tree removal $(\$ 625.02 / \mathrm{mz}$.) & 26.49 & 4.8 & 26.1 \\
\hline Coffee tree removal ( $c 9 \mathrm{l}+7.53 / \mathrm{mz}$.) & 43.55 & 5.0 & 27.2 \\
\hline Coffee tree removal (c) $389.54 / \mathrm{mz}$.) & 335.23 & 6.2 & 33.7 \\
\hline Resource reallocation & 26.49 & 4.8 & 26.1 \\
\hline
\end{tabular}

a Calculated by shifiing one manzana of the best coffee to lcssproductive use holding other production constant.

${ }^{b}$ Calculated by abandonment of one manzana of semi-abandoned coffee holding cther production constant. 
Table 41. The comparative costs of various methods of reducing coifee output on farm 15, given high fruit prices

Coffee reduction

Me thod

Bulning coffee

P.educe credit $(50 \%)$

Reduce credit $(60 \%)$

Reduce credit $(70 \%)$

Subsidize oranges ( $\$ 1.68 / 100)$

Subsidize blackberries (\$24.29/q9.)

Subsidize b!ackberries (\$85.20/qq.)

Subsidize limes (\&l.77/qq.)

Subsidize limes ( $67.24 / q 9$.

Mandatory abandonment ${ }^{a}$

Mandatory semi-abandonment

Coffee tree removal ( $6711.314 / \mathrm{mz}$.)

Resource reallocation

Resource reailocation
Cost per fanega

$\$ 215.20$

428.89

273.83

220.70

117.53

58.76

76.46

28.74

45.90

135.26

$121 . i 5$

28.74

28.74

46.90
Fanegas

Percent

17.4

100.0

1.7

9.8

3.4

19.5

5.0

28.7

10.2

58.6

6.2

35.6

13.7

78.7

9.2

52.9

14.9

35.6

10.0

57.5

8.0

46.0

9.2

52.9

9.2

52.9

14.9

85.6

${ }^{a}$ Calculated by shiftirg cne mianzana of coffee to a lessoproductive use holding other production constant. 
Table 42. The comparative costs of various methods of reducing coffee output on farm 16, given high fruit prices

Coffee reduction

Method Cost per fanega Fanegas Percent

Burning coffee

\& 215.20

3.0

100.0

Mandatory abandonment ${ }^{a}$ 185.70

2.0

65.7

Tree removal ( $\$ 3,545.77 / \mathrm{mz}$.)

$1,822.89$

1.4

46.7

Tree removal ( $\varsigma^{4}, 200.65 / \mathrm{mz}$.)

$1,927.17$

2.3

76.7

aCalculated by shifting one manzana of coffee into abandonment holding other production constant. 
Table 43. The comparative costs of various methods of reducing coffee cutput on farm 13, given low fruit prices

Coffee reduction

Me thod

Burning Coffee

Credit reduction $(10 \%)$

Credit reduction $(30 \%)$

Credit reduction $(50 \%)$

Credit reduction (70\%)

Maridatory atandonment ${ }^{a}$

Mandatory semi-abandonment ${ }^{a}$

Subsidize oranges ( $\$ 1.96 / 100)$

Subsidize aranges $(\$ 2.91 / 100)$

Subsidize limes ( $(2,81 / q q$.

Subsidize limes ( $\$ 5.71 / 09$.

Coffee tree removal (\$134.00/mz.)

Coffee tree renoval ( $\$ 577.06 / \mathrm{mz}$. )

Resource reallocation

Resource reallocation

Resource reallocetion

Resource reallocation

Resource reallocation
Cost per fanega

$\$ 215.20$

75.41

77.03

81.38

81.21

82.22

74.92

115.11

129.33

140.57

71.20

17.72

$3 i .94$

14.24

17.72

31.94

35.20

49.15
Fanegas

900.0

100.0

32.0

3.6

181.3

20.1

323.6

36.0

493.2

54.8

10.0

1.1

8.0

0.9

54.2

6.0

813.2

30.4

45.7

5.1

771.1

85.7

86.0

9.6

305.8

34.0

14.1

1.6

86.0

9.5

305.8

34.0

416.0

46.2

733.8

81.5

${ }^{a}$ Calculated by shifting one marzana of coffee lami to lessuproductive use holding other production constant. 
Table 4't. The comparative costs of various methods of reducing coffee ouiput on farm 14, given low fruit prices

Coffee reduction

Fanegas

Percent

Burning coffee

Reducing credit $(10 \%)$

६215.20

107.16

110.31

Reducing credic $(20 \%)$

238.28

Reducing credit $(30 \%)$

254.97

Reducing credit $(70 \%)$

Subsidize limes (६2.91/q9.)

343.40

Subsidize limes ( $\$ 5.56 / 99$.

133.73

Subsidize oranges $(\$ 2.91 / 100)$

130.35

279.20

Subsidize blackberries (c71.60/99.) 305.80

107.71

Mandatory semi-abardonment ${ }^{a}$

106.29

Corfee tree removal ( $\$ 959.66 / \mathrm{mz}$.

83.34

coffee tree remova! ( $\$ 1,1,76.52 / m z$.)

95.41

Coffee tree removal ( $\$ 1,746.27 / \mathrm{mz}$.)

129.54

Resource reallocation

4.78

Resource reallocation

8.32

Resource reallocation

3.00

Resource reallocation

19.78

Pesource reallocation

31.42

Resource reailccation

37.81

Resource rea!location

71.49

$70.0 \quad 100.0$

6.9

9.9

$14.2 \quad 20.3$

$17.1 \quad 24.4$

$17.9 \quad 25.6$

$21.2 \quad 30.3$

$\begin{array}{ll}51.6 & 73.7\end{array}$

$56.4 \quad 80.6$

$60.3 \quad 86.1$

$39.7 \quad 56.7$

$10.0 \quad 14.3$

$8.0 \quad 11.4$

$\begin{array}{ll}7.5 & 10.7\end{array}$

$24.7 \quad 35.3$

$53.7 \quad 76.7$

$0.2 \quad 0.3$

$3.4 \quad 4.9$

$3.7 \quad 5.3$

$9.9 \quad 14.1$

$14.8 \quad 21.1$

$18.3 \quad 26.1$

$44.4 \quad 63.4$

${ }^{a}$ Calculated by shifting one manzana of coffee to less-productive use holding other production constant. 
Table 45. The comparative costs of various methods of reducing coffee output on farm 15, given low fruit prices

Coffee reduction

Me thod

Burning coffee

Reduce credit ( $30 \%)$

Reduce credit $(50 \%)$

Reduce credit $(70 \%)$

Mandatory abandonment ${ }^{a}$

Mandatory semi-abandonment

Subsidize oranges ( $\$ 1.50 / 100)$

Subsidize oranges $(\$ 2.68 / 100)$

Subsidize !imes (

Subsidize !imes (ఢ.78/qq.)

Coffee tree removal ( $\$ 58 \mathbf{i . 0 0 / m z . )}$

Coffee tree removal ( $\xi 1,444.93 / \mathrm{mz}$ )

Coffee tree removal ( $\xi 1,748.73 / \mathrm{mz}$ )

Rescurce reallocation

Resource realiocation
Cost per fanega

६215.20

20.0

100.0

112.17

1.1

5.5

112.18

4.4

22.0

112.17

7.7

38.5

135.26

10.0

50.0

121.15

8.0

40.0

153.32

3.6

18.0

138.07

12.9

64.5

65.62

2.6

13.0

87.14

11.8

59.0

58.10

3.2

16.0

91.35

5.2

26.0

96.96

14.2

71.0

58.10

3.2

16.0

80.02

12.4

62.0

${ }^{a}$ Calculated by shiftirg one menzana of coffee to less-productive use holding other production constant. 
Table 46. The comparative costs of various methods of reducing coffee output on farm 16, given low fruit prices

Coffee reduction

Method

Burning coffee

Reduce credit $(50 \%)$

Reduce credit $(60 \%)$

Reduce credit $(70 \%)$

Mandatory abandonment ${ }^{a}$

Mandatory semi-abandonment

Subsidize oranges ( $\$ 1.60 / 100)$

Subsidize limes (\$3.02/qq.)

Subsidize 1 imes (\$5.01/q9.)

Coffee tree removal

Coffee tree renoval

Rescurce reallocation

Resource reailocation
Cost per fanega

$\$ 215.20$

438.77

280.88

309.17

152.32

135.63

557.39

139.04

321.07

$251.8 ?$

441.31

31.57

43.34
Fanegas

Percent

$9.0 \quad 100.0$

$2.7 \quad 30.0$

5.2

57.8

6.0

66.7

6.0

66.7

4.0

44.4

6.0

66.7

6.0

66.7

66.7

6.0

82.2

7.4

8.3

92.2

4.3

47.8

6.0

66.7

acalculated by shifting one manzana of coffee to less-productive use holding other production constant. 
reducing coffee output was to allow resources to be shifted to corn and beans. Where land was initially all in coffee, coffee removal subsidies were equally effective as direct controls. Subsidizing orange or lime production was over twice as costly as allowing rescurces to shift to corn and beans. Small quantities of coffee could be replaced with corn and beans at less than 10 percent of the cost of destroying harvested coffee on farms 13 and 14 . More restricted credit made it more costly to replace coffee on the smaller farms.

The following generalizations were drawn from the cost comparisons:

1. Diversified use of resources for the production of aiternative crops was a much cheaper means of reducing coffee output than either destroying harvested coffee or restricting short-term credit wi thout selectivity.

2. Blocking new coffee plantings was the cheapesi means of reducing programmed optimal coffee production.

3. Subsidizing coffee tree removal was relatively efficient on farms with all land planted to coffee but lass efficient on previously diversified farms as a means of coffee production control.

4. Subsidizing a!ternative crops was efficient as a means of coffec contro! only if the best alternative was chosen and no noncoffee land was available. Distortions in the balance of resources occurred when strawberries or blackberries vere subsiaized without provisions for exira credit and in some cases actually increased programmed coffee output.

5. In those farin situations where land was availabie that was not planted to coffee, the cheapest reduction in coffee ouput accompanied a shift of nch-land resources from coffee to al ternatives. 


\section{SUHMARY AND CONCLUSIONS}

When this study was initiatsd in 1967 , Costa Rica faced a serious and immediate threat of overproduction of coffee. Although unfavorable weather conditions in Brazil reduced the world surplus in the 1968-1969 harvest season, the threat of future overproduction stili exists.

Since farm menagement decisions affecting the quantity of coffee produced are made by the farm operators, expansion or curtailment of coffee production wili depend upon decisions made by individual farmers. With this point in view, the purpose of this study was to evaluate the farm incomes opportunities resulting from the production of coffee and alternative farm products. Comparisons between programmed optimal resource use and actual reported resource use were also used to test the hypothesis that these farmers react to price and cost stimuli in order to maximize net incone. In sddition, the effects of multiple pricing of coffee, shanges irimterest rates and cradit, subsiiy programs and other policy measurs bere e:aluated with respect lo net inconio and coffee production. Linear and peranetric programing vere

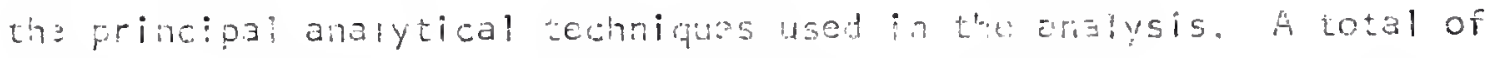
16 farns representing different resolrze siluations in three different aros of Costa Rica were used in the andigis.

\section{Effects of Improved Pesourea Al locorica}


shifting of cropping patterns. Nevertheless, given traditional alternatives, the stability of coffee acreage was assured by high costs of planting and of destroying coffee. While some farms did overproduce coffee, others underproduced in relation to optimum output. Aithough the net effect was to reduce coffee slightly on those farms included in this study, the reduction occurred only on two of the 16 farms. Therefore, the optimal allocation of resources would not reduce coffee production significantly when traditional crops are considered.

This result lerds support to Shultz's hypothesis (63, p. 14) that producers in underdeveloped countries do attempt to maximize profits and do allocate given resources efficiently. However, the high returns to additional credit, the entrance of new crops into the Todel, and the apparent misallocation of resources on certain farms indicare tha : the Costa Rican farns studied are more representative of transitional than of traditional agriculture.

On the farms studied, farmer allocation ot resources used for other crops was, for the most part, less efficiently managed than those lised to produce coffee. The only major recillocution of coffee resources occurred on the farms specializing in flue-cured tobacco. Thus, comparisons tetween reported and optimai rasource use showed a concentration of managerial effort in the major cash crops. Although education and extension nork niay be expected to incresse the efficisnisy of production of alternative crops, the Exparsion of traditional food crops does not ofter an incentive for reductions in coffee production. On the cther hand, horticuitural ciops and sugatcane may compete effectively for some resources going to coffes. The production of limes could pull resources away from coffec if subsidized longuterm credit were nade avai lable and prices were stabilias with long-term 
contracts. Considerable training and farmer education would also be required. Limes would compete more favorably with low-yielding coffee or corn and beans than with high-yielding coffee, vegetable crops or sugarcane.

Vegetable crops could potentiaily receive resources shifted out of coffee in the Alajuela area. Hovever, it was noted that vegetable crops competed more closely with sugarcane and strawberries than with coffee. When tomatoes and sweetpotatoes replaced sugarcane and beans, coffee output was not reduced by diversification. Since the risks and managerial requirements of vegetable production greatly exceed those of sugarcane production, the programmed higher returns to vecetable procuction may not be great encugh to motivate shange in that direction.

In Elimnery, while the maximization of profits may cause some chonges in production patterns, a reduction in coffee cutput requires additional action if significant changes are to be made.

\section{Effects of Taxes or Price Dezlines}

The stabi? ity oi coffee production under declining prices caused fam incomes vo be reduced drastically before output was curtailad. The specialized coffee farms incurred the greatest percentage reduction of income when prices declined. A small tax of $\$ 5.00$ or 610.00 pei fanega was ineffective in reduaing coffee production. A price dealine of 650 per fanega reduced net income over 50 percent on many coffese farins.

The supported price in the traditional coffee market was roughly 25 percent higher than the price in the rest of the world in 1967. 
Prices for coffee without the coffee agreement could be expected to fail 30 to 50 percent. If this were to happen, serious losses would occur on many spacialized farms and few coffee farms could maintain net incomes at haif of the present level.

When price declines occurred to levels representative of new cofiee market export prices, coffee cutput was reduced on most farms. This indicates that from a national viewpoint some resources are misallocated into coffee production. However, the coffee output of some of the farms, including those with highest yields, was not reduced when the coffee price was lowered to new market levels. Also most of the farnis studied produced more than 75 percent of their initial optima? coffee output at this price. This indicates that part of the resources going into coffee sold in the new market are not being misallocated.

\section{Effects of Credit Reduction}

A policy of reducing annual credit would reduce both incomes and ciop production. inccmes of those farms with intensive aiternative crops would be affected most adversely. Returns are high enough to enable coffee producers to go into unofficial money markets since the marginal returns to credit exceed 100 percent $\mathbf{i}$ i those cases where short-term ciedit limits coffee output. This policy would be effective oniy againet fankers who are wable to borrow from non-bank soulces because of low credit standing, and therefore kould be selactive agairst porer. Sire! ier sarmere. Ir.comes on these small diversified farro would be iess adverse?y erectud by policies of taxation or coffec burning than by credit rostictions. A general credit reduc- 
tion would loner coffee production but would not divert resources from coffee to alternative uses.

\section{Effects of Price Differentiation}

Theoretically, a two-price program would equate the marginal return of the farmer with the marginal leturn of the country and would avoid overallocation of resources to coffee. In practice, difficulties will arise because the base used to establish the quota for the higherpriced market may differ from optimal coffee output. It is iikely that those farms with below optimal historical production would oppose the policy as it would lower the average price of their optimal production. Those farms with a higher historical base than justified by profit maximization would benefit without necessarily lowering production beyond the ievel that gives maximum ret returns without the policy measure. Another major difficulty from a political standpoint is that the gains derived from shifting resources out of coffee are not high. Al 50 , in situations where technological advances in horticultural crops may cause a shifting of resources cut of coffee, there might be a retardation of this shift. Price differentiation would be effertive in reducing the production of coffee oniy if aliernatives surpass new market coffee in earning sbility. Major opposition may be expected from farm: where mosernization of coffee technology is underway. As wich production compl policies in the United States, the most often feare cricicism is that the pian thwarts technological change. This criticism is not justilied sine production for the new markets is a) 10usi.

III shimiary, this policy could bejuce coffee output and increase 
farm income from the levels of the base period. However, it may be argued that technological change involving new credit for alternative crops can increase income and reduce coffee production more. If this is true, price differentiation could slow diversification in periods of rapid transition.

\section{Effects of increased Credit}

increased credit may lead to an increase in coffee production on some forms and to a decrease on other farms. Intensive alternative crops giving higher net returns per manzana than coffee are required before this measure aids diversification. Where fruit and vegetable crops can be marketed, the expansion of credit could both increase income and reduce coffee output. There are situations in which income could be doublec, tripled or quadrupled by increased credit availability. However, the production of horticultural crops for industrial utilization requires new skills and technology and close supervision. It aiso involves greater risk in comparison with coffee. The expansion of credit is likely to be effective only if it is accompanied by education and supervision. It may be that oily the more efficient coffec producers can adopt the more comp! cated managerial techniques neaded for fruit and vegetabie production, Even high-yielding coffee can be replaced on land suited for vejecable und fruit production if prices are siobie and extra credit is made avail.. able. However, sinzo the markfis for these horticultural comodilies are sma!l, expansion may be limited to non-coftes land.

increased credit hrought an expansion of strawberites, sugarcane,

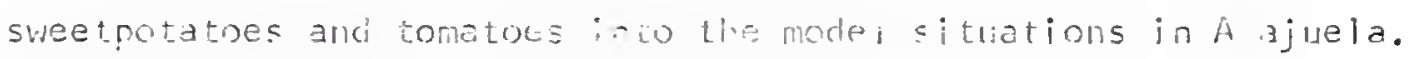


Whether these crops or other crops such as peppers or pickles are grown will deperd upon the contracts available for particular crops. The reauced shadow prices of excluded horticultural production enterprises incicated greater ease of substitutability of one vagetable for another as more credit becomes available. In the Acosta situations with high fruit prices, the production of limes and blackberries was expanded. As in Alajuela, the removal of coffee was profitable only when the demand for alternatives was sufficient to exhaust noncoffee land.

\section{The Choices of Alternative Crops}

bifferent alternatives were represented in the three zones of coffee production studiad. In the Palmarcs-san Ramón artat, income From tobacco praduction rivaled that of coffee. However, since tobecco produztion lias limited by contractual arrangements, the best exporidable aiternatives consisted of beans, sesame, corn and beans, and mixed crops. Dairy replacej part of the lower-yielding coffee in the aralysis as coffee price was lowered. Generally, the first shift, as prices of coffee were reduced, was to beans. Production pittorns borame nore complex witn diversificaiion. Credit reduction, which occumber as coffee was removed, shifted production towards subsistonco

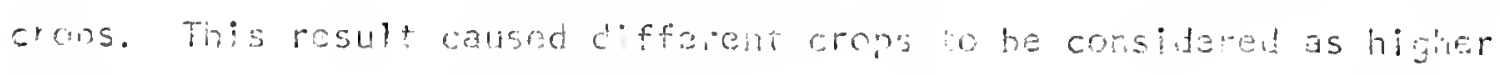
anduts: of coffee were shitted out of production. Firstiy, higher.

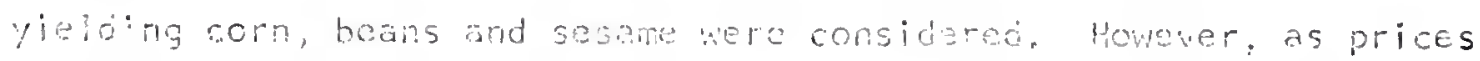
of cafiee fell, orout inas linited. Then castorbeans ard roweryeiding corr, bean and sesame aclivizies were relatively moro profitab!c. It miy be notod that, given amp!e cicdit, corn, beans and 
sesame were poor substitutes for tobacco and coffee. However, on the poorer farms or under reduced credit, low-yielding sesame and broadcast beans were among the most profitable alternatives.

The manner in which change is motivated also has an influence on which crops are produced. A credit reduction favors semi-abandoried coffee and primitively grown beans and sesame. Taxation or a price declire would first substitute the highest-yielding corn, bean or sesame alternatives but greater coffee price declines would be accompanied by a shift to traditional food crop activities. An annual payment for coffee tree removal would tend to sinift land ahead of other resources and encourage less intensive production alternatives.

In Alajuela, vegetable crops and sugarcane compete favorably with established coffee that yields 20 fanegas per manzana or less. However, credit restrictions and market limitations make largo-scale changes in resource allecation uneconomica!. Tomatoes and sweetpotatoes showed the most potential as substitutes for coffee in the model but relatively small pirice iluctuations could bring peppers. strawberries, cucumbers and other vegetables into production. Sugarcane also competed for resources shifted from coffee. As prices were reduced, sugarcare replaced high-yielding coffee on the largest farr studied. A difference in resource allocation occurred bith frice decines with specific results depending upon the efficiency of coffee production and cradit limitations. Sugarcane was favored cver vegetables when the permanent labor supply was exhausted and i imes were favored over vegerables when short-term ciedit was nore rimited.

Whon credit was increased, strawoery, sweetpoiato and Lomato proúction increased. When credit was rejuced severely, seminabandored 
coffee and traditional creps of corn and beans became the most profitable activities.

The expansion of horticultural crops depends upon stable high prices for industrial use. Fresh fruit and vegetables for the domestic market receive much higher prices but also face considerable risk. These combinations of high average prices and high risks have checked modernization of technology. Conservative management po!icy cuts input cost to minimize loss in years of low prices or at least to hold risk's to some acceptable level. This interplay of risks and profits in decision-making processes cause actual resource use to deviate from long-run profit maximizacion. An additional factor of small market size aiso affects decision making. Each of a few producers may be able to influence price; therefore, the high domestic price levels were not used in the analysis of fruit and vegetable alternatives. Opposition to policies favoring the industrialization of horticultural producis may be expected from fruit and vegetable producers currently' serving the fresh produce market.

In Acosta, high fruit prices brought large shifts in resources from coffee to limes. Blackberries could be enccuraged by incrased credit in eddition to stable high industrial pricas. Additicra! changes to be brought about by other policy rieasures would be slon to occur and relativeiy unimportant.

when low fruit prices were used in the amalysis, coftee wes replared by corn and beans with moderarely small declines in tha coffee price. Pocryielding coffee could be removed by taxation or market price declines. But the shorkrun best allocation of resources would be disastrous over a long tine period. The topography is rough 
and unsuited to row crops. Erosion and leaching of soils exposed to heavy rains would bring a continuing decline of productivity to farms in the ficosta area.

\section{Comparative Costs of Coffee Removal}

The costs of reducing optimal coffee output using varicus policy measures were calculated for 20 farm situations. Wide differences occurred from farm to farm and among methods.

In general, low-yielding coffee was cheaper to remove than highyielding coffee. However, the costs of coffee raduction increased as the quantity reduced on a particular farm increased. The productivity of the alternatives also entered into the costs of reducing coffee output. For exampie, it was cheaper to remove 25 fanegas per manzana of coffee fron an Alajuela farm with horticultural crops among its alternatives than to remove 19 fanegas per manzana of coffee from a Farm in Paimeres with poorer alternative possibilities. Credit restrictions on poorer farms blocked higher return alternatives and raised the comparative costs of reducing coffee above the costs of reducing better yielding coffee cn more profitabie farms. Smali rejuctions in coffee ouput were made most cheaply on averege or iower yielding farms. However, when larger reductions in coffee output required destruction of coffee trees, the credit constraint caused the costs to increase more rapidly on those iower yielding farns which also had less operatirg capital per manzana.

When cofree tree removal was programmed as the means to reduce cofree cutput, highest costs var associated with the poorcst ferms. With tha excepzions of the porrest farma, the costs of removing trees 
that produced one fanega of coffee from production were below the costs of burning coffee after it had been produced. Generally, costs ranged upward from cl4 per fanega and were clustered below \$l00. Reducing inputs to coffee, as a means of reducing output, can be expected to cost \&75 to \&l25 per fanega when infuts are not reallocated to other uses.

Credit reductions sometimes reduced the production of other crops. When this occurred, credit reductions were an extremely expensive way of reducing coffee output. Costs ranged from \&75 to over $\$ 2,000$ per fanega of reduction in coffee output.

Blocking new plantings reduced optimal coffee output slightly on two farms. A tax or injunction against new piantings would not greatly reduce potentia! incomes with present price relationships.

\section{Fotential Effects of Technolocical Advances in coffee Production}

The major threat to the acceptance of a program of crop diversification is that technological changes in coffee production will be easier to initiate than more complex changes in rarm márgement which, shift resources out of coffee. Furthermore, given prescht prices, ine returns to modernized coffee production surpass returns to a! ternatives that compete with coffee for the allocation of current resources o: most farms. Many farms would double net incomes and expand cofree production if mors productive coffere-grouing activities could be employed. Even with prices or yie?ds lowered 20 percent, the majority of the farms studiej would increase ret income by adopting new coffee technology. The increased coffee output expected from technological change would offsat reductions oxpected from diversification of rurent 
resources. The costs of reallocating resources to reduce coffee output will be increased by advances in coffee production technology. The programmed incomes on seven out of eight farms with fruit or vegetable alternatives were higher when credit was increased than when coffee technology was changed. Therefore, if production of coffee is to be held in check by voluntary means, large increases in the supply of credit for horticultural crops must be made along with investments for processing plants and extension programs. Involuntary production controls using farm quotas is another way of checking the potential expansion.

\section{The Qualifications of an Acceptable Alterrative}

in a study of this nature, all possible crops cannot be included because of time and cost restrictions. However, from the crops studied, certain patterns were incicated. An alternative must net higher returns per manzana than coffee if it is to cause coffee trees to be destroyed and the land planted to another crop. The difference must be high enough to pay for coffee tree removal.

Snalier downward adjustments in coffee production can occur when an altermative is superior to other non-coffec crops and competes with coffee for non-land resources. One may expect such changes to be temporary since over time increased ircome may al low purchases of additional inputs.

Before intensive, horticulturai crops replace significant quantities of coffee, additionai credit is required.

0. nost coffee farms, labor does not appear to be a critically limiting factor of production. Therefore, an acoeptable alternative may use more hour-wage lator than coffec. 
Finally, the alternative crop must face a stable price. Profit maximization is a rational al ternative only after risk against loss is held to an acceptable level. Despite downward trends over the past few years, cofree prices in comparison with alternatives have been reasonably stable.

\section{Diversification Versus Production Contro!}

Crop diversification and coffee production control are not identical. Diversification can be raticnally expanded in coffee growing regions. Diversification is a relative rather than an absolute concept. The benefits of risk reduction, income increases and tax-base expansion occur when the production of other crops is expanded whether or not coffee output is reduced. This analysis shows that some opportunity for crop diversification does exist. However, the projections of results of farm case studies to broader generalizations do not justify optimisin that crop diversification can effectively contro! coffee cutput, Morecver, other factors influence decision making in addition to annual net income incentives. The higher levei of risk and the need for closer supervision may biock certain aetivities even when requirements for new technical knowledge are supplied.

firedit reduction can limit coffee production without aiding diver-

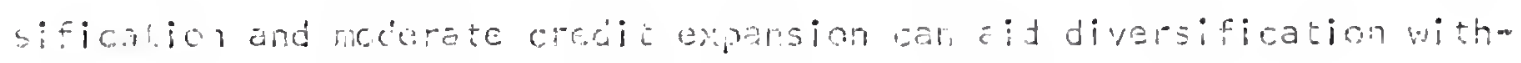
out liniting coffer output.

Profitabie diversificatim alternatives inver the opportunity cost associated with involuntary redectirns of cofree ontput. In comparison with the destruction of harvested coffee, the reallacation of resources to alferiative uses is much cheaper as a means of controlling national 
coffee sales. Likewise a program of quotas, payiment for coffee tree removal, subsidics to alternative crops, or selective credit allocation probably would maka diversification more acceptable to farmers. 


\section{GLOSSARY}

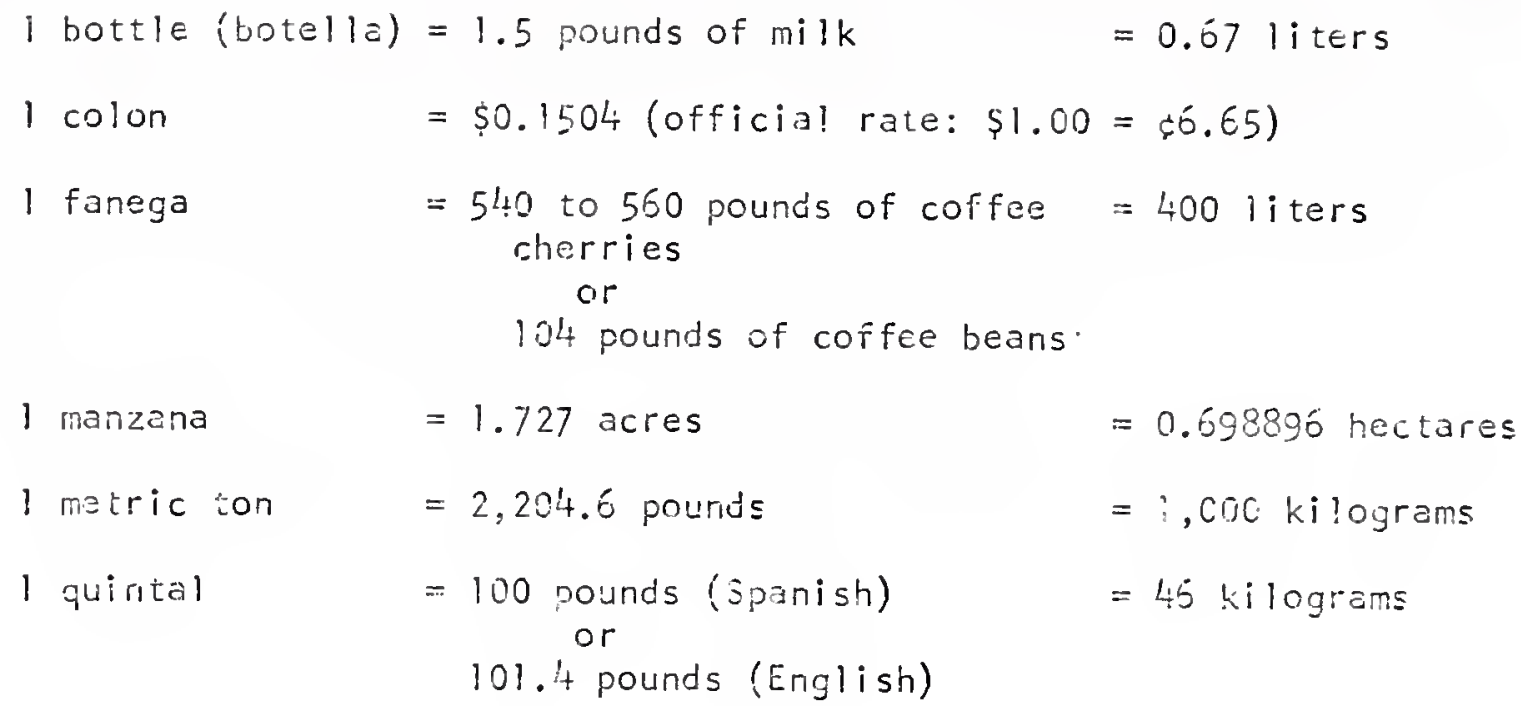


APPENDIX 


\section{Introduction to the Appendix}

The inplit and output coefficients used in this analysis are included in the Appendix. Changes in technology will undoubtedly alter yield's and both quantity and quality of inputs used. The results and conclusions reached in this study will hold only as long as the yield and input coefficients are representative of existing relationships.

The following units of measure apply to the data in the appendix tables.

All labor, labor supervision and family harvest labor were recorded in hours.

The monetary urit is the color $(c 6.65=\$ 1.00)$. The entries in the investment rows were made in units of 100 colones. The other monetary itsms are in units of one colon.

Liand entries are in units of one manzana. Monthiy entries were combined in the appendix tables with the first and last nonths designated.

Output cefficients varied from crop to crop. The rost common whit, the quintai (ioo spanish pounds), was used for the foilowing crops: corn, beans, sweetpotatoes, cassave, buckinear, pigeon peas, chickpas, limes, tobacco, straberries and blackoerries. Metric ton was used as the unit of production for sugercane, tomatoes and peppers. Banane output was entered in units of 100 stems and orange output was entered in units of 100 fruits. Milk output was entered in units of 100 botties (1.5 pounds each).

In a number of the appendix tables moriths of labor were cmilted when no inhor was required. Also, in order to conserve space, one or more digits to the right of the decimal, as used in che programing andyses, were onit tod in the aumenotix tabics. 
Coefficients for coffee producing activities 1 through 5, PalmaresSan Ramón

\begin{tabular}{|c|c|c|c|c|c|}
\hline \multirow[b]{2}{*}{ Item } & \multicolumn{5}{|c|}{ Activity } \\
\hline & 1 & 2 & 3 & 4 & 5 \\
\hline Profit & -620.00 & -633.55 & -645.25 & -553.05 & $-1,486.75$ \\
\hline January labor & 0 & 0 & 1.00 & 0 & 0 \\
\hline March labor & 24.00 & 18.00 & 50.00 & 36.00 & 132.00 \\
\hline April iabor & 50.00 & 29.00 & 28.00 & 0 & 100.00 \\
\hline May lebor & 103.00 & 31.00 & 32.00 & 12.00 & 152.00 \\
\hline June labor & 23.00 & 22.00 & 35.00 & 66.00 & 80.00 \\
\hline July labor & 15.00 & 23.00 & 5.00 & 48.00 & 18.00 \\
\hline August labor & 49.00 & 13.00 & 28.00 & 30.00 & 88.00 \\
\hline September labor & 20.00 & 13.00 & 0 & 72.00 & 84.00 \\
\hline October labor & 64.00 & 9.00 & 0 & 0 & 128.00 \\
\hline November labor & 0 & 0 & 1.00 & 60.00 & 0 \\
\hline Irives tment & $13.00^{b}$ & $12.80^{b}$ & $7.45^{c}$ & 0 & 0 \\
\hline Operating capita? & 451.00 & 467.85 & 509.50 & 438.00 & $1,284.00$ \\
\hline Rotation, castorbeans & 1.00 & 1.00 & 1.00 & 1.00 & 1.00 \\
\hline Rotation, beans & 1.00 & 1.00 & 1.00 & 1.00 & 1.00 \\
\hline Land, all year & 1.00 & 1.00 & 1.00 & 1.00 & 1.00 \\
\hline Coffée land maximum & 1.00 & 1.00 & 1.00 & 1.00 & 1.00 \\
\hline Coffee land minimum & 1.00 & 1.00 & 1.00 & 1.00 & 1.00 \\
\hline Yield transfor & $=27.50^{d}$ & $-25.70^{b}$ & -19.00 & $=15.00$ & 20.00 \\
\hline Yield change & 27.60 & 25.70 & 19.00 & 15.00 & 20.00 \\
\hline
\end{tabular}

"This activity was blocked on Farns 3 and 4 .

this entry of investrient in hundreds of coiones was not useri on farms 1 and 2 where the investment had already been made.

CThis investment entry was used only for Farms 3 and 4.

din this activity, yild has placed directly into the coffee transfer row unly in Farms ard 2. Parametrir programming procedures alloned this activity to be considered on Farms 3 through 8. 

Coefficients for coffee producing activities 6 through 10, Palmares-
Sari Ramón

\begin{tabular}{|c|c|c|c|c|c|}
\hline \multirow[b]{2}{*}{ Item } & \multicolumn{5}{|c|}{ Activity } \\
\hline & $6^{a}$ & 7 & 8 & 9 & 10 \\
\hline Profit & -482.40 & -156.25 & --770.00 & -20.00 & -375.00 \\
\hline January labor & 0 & 0 & 0 & 0 & 0 \\
\hline February labor & 0 & 0 & 0 & 0 & 0 \\
\hline March labor & 36.00 & 60.00 & 132.00 & 0 & 60.00 \\
\hline April labor & 20.00 & 60.00 & 15.00 & 20.00 & 30.00 \\
\hline May iabor & 37.00 & 75.00 & 0 & 0 & 18.00 \\
\hline june labor & 12.00 & 75.00 & 48.00 & 0 & 6.00 \\
\hline July labor & 31.00 & 35.00 & 36.00 & 0 & 0 \\
\hline August labor & 12.00 & 50.00 & $2^{i}+.00$ & 45.00 & 16.00 \\
\hline September labor & 0 & 50.00 & 36.00 & 45.00 & 30.00 \\
\hline October labor & 7.00 & 0 & 0 & 0 & 0 \\
\hline November labor & 0 & 0 & 0 & 0 & 0 \\
\hline December labor & 0 & 0 & C & 0 & 0 \\
\hline Investrient & 0 & 0 & 0 & 0 & 0 \\
\hline Operating capital & 405.00 & 103.00 & 664.00 & 0 & 322.70 \\
\hline Rotation, castorbeans & 1.00 & 1.00 & 1.00 & $i .00$ & 1.00 \\
\hline Rotdtion, beens & 1.00 & 1.00 & 1.00 & 1.00 & 1.00 \\
\hline larid, all year & 1.00 & 1.00 & 1.00 & 1.00 & 1.00 \\
\hline Coffee iand maximum & 1.00 & 1.00 & 1.00 & 1.00 & 1.00 \\
\hline Coffee land mininum & 1.00 & 1.00 & 1.00 & 1.00 & 1.00 \\
\hline Yield transfer & -15.00 & -9.00 & -15.00 & -4.00 & -5.30 \\
\hline Yield change & 15.00 & 9.00 & $i 5.00$ & 4.00 & 5.30 \\
\hline
\end{tabular}

ahis activity was biocked or Fams 3 and 4. 
Coefficients for flue-cured tobacco producing activities, PalmaresSan Ramón

Activity

\begin{tabular}{|c|c|c|c|}
\hline tem & 1 & 2 & 3. \\
\hline Profit & $-2,617.70$ & $-2,324.80$ & $-2,785.70$ \\
\hline \multicolumn{4}{|l|}{ Labor: } \\
\hline January & 377.00 & 200.00 & 125.00 \\
\hline February & 59.00 & 277.00 & 0 \\
\hline ilarch & 0 & 120.00 & 0 \\
\hline June & 30.00 & 0 & 0 \\
\hline July & 260.00 & 0 & 180.00 \\
\hline August & 115.00 & 248.00 & 69.00 \\
\hline September & 230.00 & 118.00 & 153.60 \\
\hline October & 159.00 & 30.00 & 93.00 \\
\hline November & 315.00 & 0 & 22.00 \\
\hline December & 510.00 & 0 & 137.00 \\
\hline \multicolumn{4}{|l|}{ I.and: } \\
\hline June-January & 1.00 & 0 & 0 \\
\hline July-Jariary & 0 & 0 & 1.00 \\
\hline August-Jenuary & 0 & 1.00 & 0 \\
\hline Inves timent & 20.00 & 20.00 & 20.00 \\
\hline Operating capital & $2,430.95$ & $2,231.00$ & 2.703 .30 \\
\hline Flue.cured contract & 1.00 & 1.00 & 1.00 \\
\hline Tobacco transfer, flue & 20.00 & 17.60 & 18.80 \\
\hline
\end{tabular}


Coefficients for burley tobacco producing activities, PalmaresSan Ramón

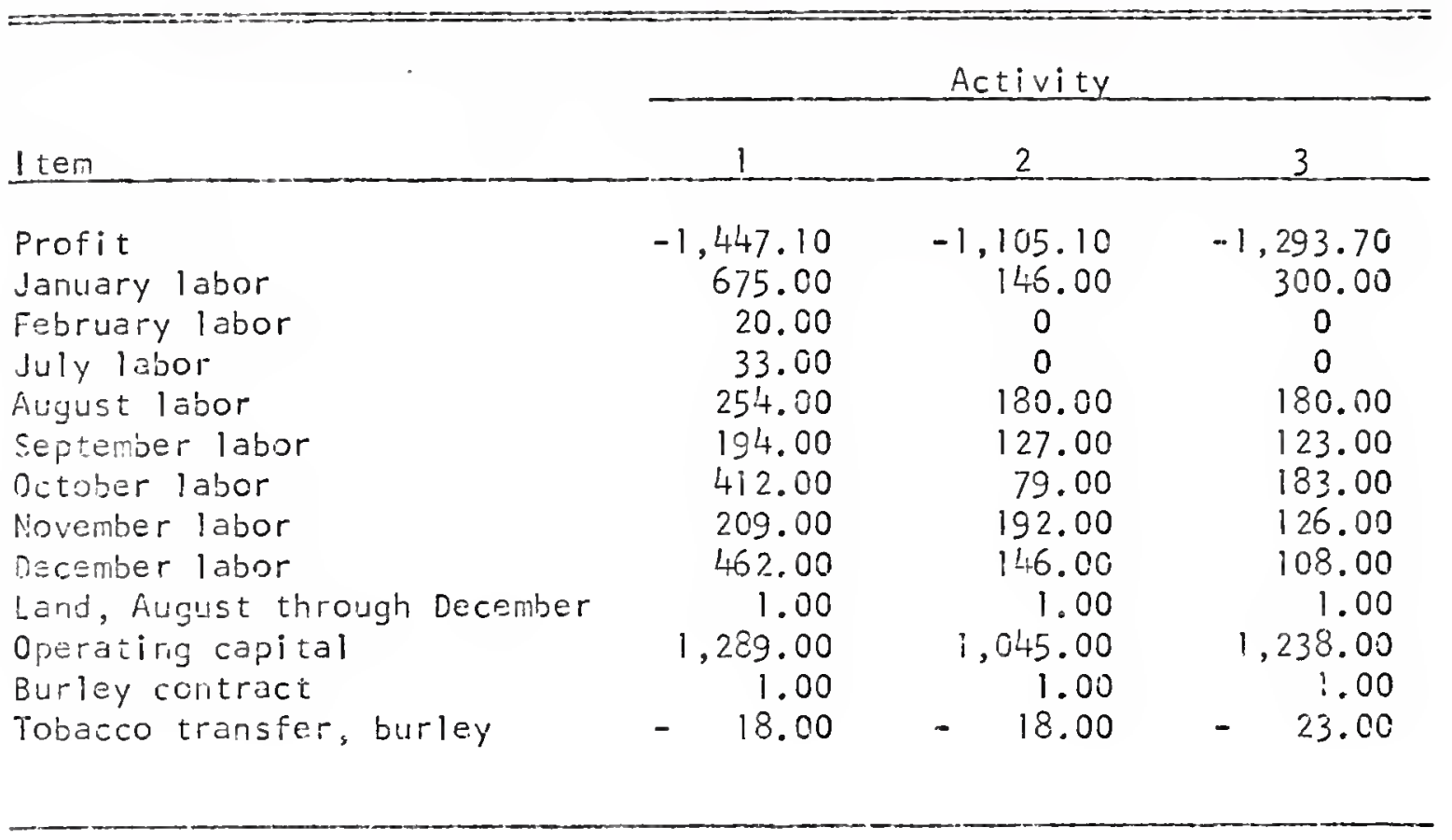


Coefficients of sun-cured tobacco producing activities, PalmaresSan Ramón

\begin{tabular}{|c|c|c|c|}
\hline \multirow[b]{2}{*}{1 tem } & \multicolumn{3}{|c|}{ Activity } \\
\hline & 1 & 2 & 3 \\
\hline $\begin{array}{l}\text { Profit } \\
\text { Labor: }\end{array}$ & $-1,031.40$ & -757.95 & $-1,028.80$ \\
\hline January & 0 & 210.00 & 0 \\
\hline February & 589.0 & 200.00 & 210.00 \\
\hline March & 68.00 & 0 & \\
\hline July & 44.00 & 0 & \\
\hline August & 172.00 & 0 & 204.00 \\
\hline September & 153.00 & 126.00 & 59.00 \\
\hline October & 196.00 & 72.00 & 137.00 \\
\hline November & 57.00 & 168.00 & 98.00 \\
\hline December & 320.00 & 0 & 186.00 \\
\hline \multicolumn{4}{|l|}{ Land: } \\
\hline August-December & $1.5 C$ & 0 & 1.00 \\
\hline Septerber-Janlary & 0 & 1.00 & 0 \\
\hline Operating capital & 905.00 & 709.10 & 970.00 \\
\hline Sun-cured contract & 1.00 & 1.00 & 1.00 \\
\hline Tobarco transfer. sun & 13.00 & -19.03 & 20.00 \\
\hline
\end{tabular}


Coefficients of corn producing activities 1 through 4, PaimaresSan Ramón

Activity

\begin{tabular}{lcccc} 
Item & 1 & 2 & 3 & 4 \\
\hline $\begin{array}{l}\text { Profit } \\
\text { Labor: }\end{array} \quad-484.50$ & -484.50 & -352.15 & -352.15 \\
$\quad$ January & 90.00 & 0 & 66.00 & 0 \\
April & 172.00 & 172.00 & 72.00 & 72.00 \\
May & 90.00 & 90.00 & 72.00 & 72.00 \\
June & 98.00 & 98.00 & 66.00 & 66.00 \\
July & 18.00 & 18.00 & 4.00 & 4.00 \\
August & 18.00 & 18.00 & 14.00 & 4.00 \\
September & 0 & 0 & 18.00 & 0 \\
October & 0 & 90.00 & 0 & 66.00 \\
Land: & 1.00 & 0 & 0 & 0 \\
April-January & 0 & 1.00 & 0 & 1.00 \\
April-Octcber & 0 & 0 & 1.00 & 0 \\
ilarch-January & 351.40 & 351.40 & 259.40 & 259.40 \\
Operating capital & -69.00 & -70.00 & -48.00 & -49.00 \\
Corn sheiling & -69.00 & -70.00 & -48.00 & -49.00 \\
Corn transfer & -351.40 & -351.40 & -259.40 & -259.40 \\
Special credit & & & &
\end{tabular}


Coefficients of corn producing activities 5 through 8, PalmaresSan Ramón

\section{Astivity}

\begin{tabular}{|c|c|c|c|c|}
\hline Item & 5 & 6 & 7 & 8 \\
\hline Profit & -156.50 & -102.85 & -142.95 & -142.95 \\
\hline \multicolumn{5}{|l|}{ Labor: } \\
\hline January & 0 & 0 & 0 & 60.00 \\
\hline March & 84.00 & 48.00 & 0 & 0 \\
\hline April & 0 & 0 & 19.00 & 19.00 \\
\hline May & 66.00 & 8.00 & 24.00 & 24.00 \\
\hline June & 54.00 & 56.00 & 41.00 & 41.00 \\
\hline July & 18.00 & 0 & 2.00 & 2.00 \\
\hline Septeminer & 0 & 0 & 0 & 10.00 \\
\hline October & 66.00 & 18.00 & 30.00 & 0 \\
\hline November & 0 & $i 8.00$ & 0 & 0 \\
\hline \multicolumn{5}{|l|}{ Land: } \\
\hline March-0ctober & 1.00 & 0 & 0 & 0 \\
\hline March-Novemiber & 0 & 1.00 & 0 & 0 \\
\hline April-Juiy & 0 & 0 & 1.00 & 1.00 \\
\hline Operating capital & 95.01 & 71.00 & 113.40 & 113.40 \\
\hline Corn shelling & -40.00 & -24.00 & -13.00 & -13.00 \\
\hline Corn transfer & -40.00 & -24.00 & -13.00 & -13.00 \\
\hline Special credit & -95.00 & -71.00 & -113.40 & -113.40 \\
\hline
\end{tabular}

aThinly planted corn allows another crop to be planted after July. 
Coefficients of corn-bean producing activities 1 through 4, PalmaresSan Ramón

Activity

\begin{tabular}{|c|c|c|c|c|}
\hline Item & 1 & 2 & 3 & 4 \\
\hline $\begin{array}{l}\text { Profit } \\
\text { Labor: }\end{array}$ & -447.50 & -251.95 & -163.00 & -162.10 \\
\hline January & 54.00 & 0 & 0 & 60.00 \\
\hline March & 0 & 84.00 & 0 & 48.00 \\
\hline April & 72.00 & 0 & 19.00 & 0 \\
\hline May & 72.00 & 102.00 & 0 & 56.00 \\
\hline June & 66.00 & 86.00 & 53.00 & 68.00 \\
\hline July & 4.00 & 18.00 & 2.00 & 12.00 \\
\hline August & 4.00 & 66.00 & 72.00 & 72.00 \\
\hline september & 18.00 & 44.00 & 66.00 & 66.00 \\
\hline October & 152.00 & 60.00 & 20.00 & 20.00 \\
\hline November & 60.00 & 0 & 20.00 & 20.00 \\
\hline Decenber & 0 & 0 & 0 & 20.00 \\
\hline \multicolumn{5}{|l|}{ Land: } \\
\hline March-January & 1.00 & 0 & 0 & 0 \\
\hline March-October & 0 & 1.00 & 0 & 0 \\
\hline March-Augusta & 0 & 0 & 1.00 & 0 \\
\hline April-August & 0 & 0 & 0 & 1.00 \\
\hline Operating capital & 353.80 & 113.70 & 129.60 & 89.00 \\
\hline Rotation, beans & 1.00 & 1.00 & 1.00 & 1.00 \\
\hline corr sheiling & -48.00 & -40.00 & -13.00 & -24.00 \\
\hline Corn transfer & -48.00 & -40.00 & -13.00 & -24.00 \\
\hline Bean transfer & $\therefore \quad 9.6 \mathrm{C}$ & -4.00 & $=5.40$ & -5.40 \\
\hline Special credit & -353.80 & -113.70 & .129 .60 & -89.00 \\
\hline
\end{tabular}

after bean harvest the thinly folanted corn allowed another crcp to be planied. 
Coefficients for bean producing activities 1 through 4, PalmaresSan Rámún

Activity

\begin{tabular}{lcccc} 
Item & i & 2 & 3 & 4 \\
\hline $\begin{array}{l}\text { Profit } \\
\text { Labor: }\end{array}$ & -396.95 & -289.85 & -116.10 & -62.10 \\
January & 57.00 & 0 & 60.00 & 60.00 \\
February & 0 & 0 & 0 & 28.00 \\
April & 0 & 280.00 & 0 & 0 \\
May & 0 & 90.00 & 0 & 0 \\
June & 0 & 98.00 & 0 & 0 \\
July & 0 & 57.00 & 0 & 0 \\
August & 240.00 & 18.00 & 0 & 0 \\
September & 92.00 & 47.00 & 0 & 0 \\
October & 51.00 & 108.00 & 80.00 & 22.00 \\
November & 12.00 & 0 & 0.00 & 0 \\
December & 47.00 & 0 & 0 & 0 \\
Land: & 1.00 & 0 & 0 & 0 \\
September-January & 0 & 0 & 1.00 & 0 \\
October-Jariuary & 0 & 0 & 0 & 1.00 \\
October-February & 0 & 1.00 & 0 & 0 \\
April-September & 352.35 & 261.35 & 94.40 & 51.70 \\
Operating capital & 1.00 & 1.00 & 1.00 & 1.00 \\
Rotation, beans & -20.00 & -18.00 & -9.50 & -1.20 \\
Bean transfer & -352.35 & -261.35 & -94.40 & -51.70 \\
Speciai cradit & & & &
\end{tabular}


Coefficients for sesame and castorbean producing activities, PalmaresSan Ramón

\begin{tabular}{|c|c|c|c|c|}
\hline \multirow[b]{2}{*}{1 tem } & \multicolumn{2}{|c|}{ Sesane } & \multicolumn{2}{|c|}{ Castorbean } \\
\hline & 1 & 2 & 1 & 2 \\
\hline $\begin{array}{l}\text { Profit } \\
\text { Labor: }\end{array}$ & -267.90 & -36.25 & -450.85 & -268.45 \\
\hline January & 120.00 & 80.00 & 0 & 0 \\
\hline February & 110.00 & 36.00 & 0 & 0 \\
\hline April & 0 & 0 & 72.00 & 72.00 \\
\hline Mày & 0 & 0 & 22.00 & 78.00 \\
\hline June & 0 & 0 & 3.00 & 60.00 \\
\hline July & 0 & 0 & 15.00 & 54.00 \\
\hline September & 0 & 72.00 & 0 & 0 \\
\hline October & 272.00 & 88.00 & 90.00 & 90.00 \\
\hline November & 48.00 & 36.00 & 120.00 & 100.00 \\
\hline \multicolumn{5}{|l|}{ Land: } \\
\hline September-January & 0 & 1.00 & 0 & 0 \\
\hline October-January & 1.00 & 0 & 0 & 0 \\
\hline Apri i-October & 0 & 0 & 1.00 & 1.00 \\
\hline Operating sapital & 228.75 & 19.00 & 370.25 & 203.70 \\
\hline Rotation, casturbean & 0 & 0 & 5.00 & 5.00 \\
\hline Sesame cransfer & -20.00 & -11.00 & 0 & 0 \\
\hline Castorbsan transfer & 0 & 0 & -34.00 & -32.00 \\
\hline Special credit & -228.75 & -19.00 & -370.25 & -203.70 \\
\hline
\end{tabular}


Coefficients for dairy activities, Palmares-San Ramón

Activities

\begin{tabular}{|c|c|c|c|c|c|}
\hline Item & 1 & 2 & 3 & 4 & 5 \\
\hline Profit & $-4,6.9$ & -68.7 & -63.0 & -467.2 & -188.2 \\
\hline $\begin{array}{l}\text { Labor: } \\
\text { January }\end{array}$ & 200 & 150 & 150 & 10 & 10 \\
\hline February & 20.0 & 15.0 & 15.0 & 10.0 & 10.0 \\
\hline March & 20.0 & 15.0 & 15.0 & 10.0 & 10.0 \\
\hline April & 20.0 & 15.0 & 15.0 & 10.0 & 10.0 \\
\hline May & 20.0 & 15.0 & 15.0 & 10.0 & 10.0 \\
\hline June & 27.0 & 15.0 & 15.0 & 17.0 & 17.0 \\
\hline July & 24.0 & 29.0 & 35.0 & 10.0 & 10.0 \\
\hline August & 24.0 & 23.0 & 35.0 & 14.0 & 14.0 \\
\hline September & 24.0 & 15.0 & 35.0 & 10.0 & $i 0.0$ \\
\hline October & 24.0 & 15.0 & 15.0 & 10.0 & 10.0 \\
\hline November & 20.0 & 15.0 & 15.0 & 10.0 & 10.0 \\
\hline December & 20.0 & 15.0 & 15.0 & 10.0 & 10.0 \\
\hline Land & 2.5 & 2.5 & 5.0 & 1.0 & 1.0 \\
\hline Operating capital ${ }^{a}$ & $2,285.9$ & 608.7 & 603.0 & $1,277.2$ & 977.2 \\
\hline Rotation, castorbecns & 2.5 & 2.5 & 5.0 & 1.0 & 1.0 \\
\hline Rotation. bear:s & 2.5 & 2.5 & 5.0 & 1.0 & 1.0 \\
\hline livestmer.t & 19.0 & 6.0 & 6.0 & 9.0 & 9.0 \\
\hline Milk transfer & -30.0 & -10.0 & -10.0 & -20.0 & -10.0 \\
\hline Calf transfer & 0 & -0.9 & -0.8 & -0.9 & -0.8 \\
\hline Speciai credit & -2.286 .9 & -603.7 & -603.0 & $-1,277.2$ & -977.2 \\
\hline
\end{tabular}


Coefficients for teef and pigeon pea and mixed crop producing activities, Pa!mares-San Ramón

\begin{tabular}{|c|c|c|c|c|}
\hline \multirow[b]{2}{*}{ Item } & \multicolumn{2}{|c|}{ Beef } & \multirow{2}{*}{$\begin{array}{c}\text { Pigeon } \\
\text { pea }\end{array}$} & \multirow{2}{*}{$\begin{array}{r}\text { Mixed } \\
\text { crop } \\
\end{array}$} \\
\hline & 1 & 2 & & \\
\hline Profit & -142.00 & -63.00 & -308.90 & -478.20 \\
\hline \multicolumn{5}{|l|}{ Labor: } \\
\hline January & 5.00 & 1.00 & 6.00 & 5.00 \\
\hline February & 5.00 & 1.00 & 6.00 & 86.00 \\
\hline March & 5.00 & 1.00 & 160.00 & 120.00 \\
\hline April & 5.00 & 1.00 & 240.00 & 240.00 \\
\hline May & 5.00 & 1.00 & $i 70.00$ & 170.00 \\
\hline June & 13.00 & 34.00 & 40.00 & 74.00 \\
\hline July & 13.00 & 34.00 & 0 & 12.00 \\
\hline August & 13.00 & 34.00 & 6.00 & 6.00 \\
\hline Sepiember & 5.00 & 1.00 & 6.00 & 118.00 \\
\hline Dctober & 5.00 & 1.00 & 240.00 & 140.00 \\
\hline November & 6.00 & 2.00 & 0 & 160.00 \\
\hline December & 5.00 & 1.00 & 0 & 22.00 \\
\hline Land, all year & 1.50 & 5.00 & 1.00 & 1.00 \\
\hline Operating capitai & 862.00 & 603.00 & 272.00 & 386.20 \\
\hline Investment & 8.00 & 6.00 & 0 & 0 \\
\hline Rotation, zastorbeans & 1.50 & 5.00 & 0 & 0 \\
\hline Rotation, beans & 1.50 & 5.00 & 1.00 & 1.00 \\
\hline Calf transfer & $\therefore \quad 0.75$ & -0.50 & 0 & 0 \\
\hline Pigeon pea transfer & 0 & 0 & -20.00 & -13.00 \\
\hline Corn transfer & 0 & 0 & 0 & -30.00 \\
\hline Bean transfer & 0 & 0 & 0 & -4.80 \\
\hline Chickpea transfer & 0 & 0 & 0 & -4.00 \\
\hline Special credit & -862.00 & .603 .00 & -272.00 & -366.00 \\
\hline
\end{tabular}


Coefficients for peanut, chickpea and buckwheat producing activities, Palmares-San Ramón

\begin{tabular}{|c|c|c|c|c|}
\hline \multirow[b]{2}{*}{1 tem } & \multirow[b]{2}{*}{ Peanut } & \multirow[b]{2}{*}{ Chickpea } & \multicolumn{2}{|c|}{ Buckwheat } \\
\hline & & & 1 & 2 \\
\hline $\begin{array}{l}\text { Profit } \\
\text { Labor: }\end{array}$ & -362.0 & -82.6 & -105.7 & -56.8 \\
\hline January & 0 & 66.0 & 180.0 & 12.0 \\
\hline February & 0 & 20.0 & 0 & 0 \\
\hline March & 0 & 0 & 0 & 120.0 \\
\hline August & 442.0 & 0 & 0 & 0 \\
\hline September & 48.0 & 0 & 0 & 0 \\
\hline October & 12.0 & 22.0 & 0 & 0 \\
\hline November & 72.0 & 0 & 12.0 & 0 \\
\hline Land: & & & & \\
\hline August-Novenber & 1.0 & 0 & 0 & 0 \\
\hline 0ctober-February & 0 & 1.0 & 0 & 0 \\
\hline November-january & 0 & 0 & 1.0 & 0 \\
\hline January-Marci & 0 & 0 & 0 & 1.0 \\
\hline Operating capitai & 312.0 & 77.2 & 72.5 & 40.4 \\
\hline Peanut transfer & $=20.0$ & 0 & 0 & 0 \\
\hline Buckwhest transfer & 0 & 0 & -20.0 & -8.0 \\
\hline Chickpee transfer & 0 & -5.0 & 0 & 0 \\
\hline Special credit & -312.0 & -77.2 & -72.5 & -40.4 \\
\hline
\end{tabular}


Coffee picking activities, all areas ${ }^{a}$

Coffee picking aztivity

Item January Fóruary November December

$\begin{array}{lllll}\text { Profit } & 1.0 & 1.0 & 1.0 & 1.0\end{array}$

Labor:

$\begin{array}{lllll}\text { January } & 1.0 & 0 & 0 & 0 \\ \text { February } & 0 & 1.0 & 0 & 0 \\ \text { November } & 0 & 0 & 1.0 & 0 \\ \text { December } & 0 & 0 & 0 & 1.0\end{array}$

${ }^{a}$ An additionel picking activity for October coffee picking is included elsewhere for the Acosta area. 
Coeficients for coffee harvesting and corn shelling operations, Palmares-San Ramón

Coffee harvesting

Item

Profit

All labor: January

February

November

December

Family labor only:

January

February

November

December

Coffee harvest

Corn shelling

Hired Family

$-40.00$

0.50

0.50

0.50

0.50

0

5.00

4.00

4.00

5.00

0

0

0

0

1.00

0
5.00

4.00

4.00

5.00

1.00

0
Corn shelling

Hand labor Contract

$0 \quad-1.00$

2.50

0

0

0

0

$\begin{array}{ll}0 & 0 \\ 0 & 0\end{array}$




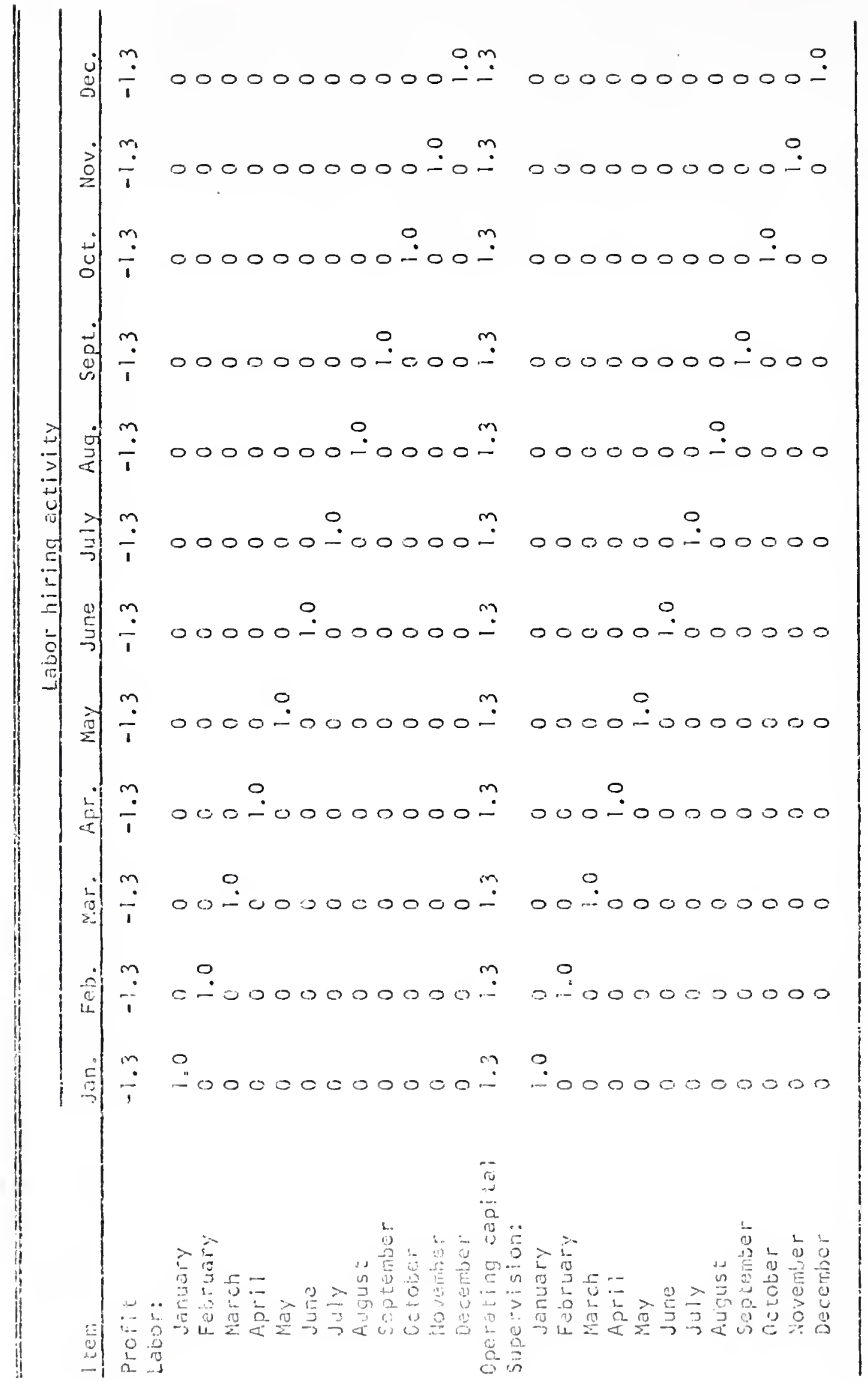


Coefficienis for borrowing, planting coffee, destroying coffee, and fixed costs transfer activities, all areas

\begin{tabular}{|c|c|c|c|c|}
\hline \multirow[b]{2}{*}{ Iter. } & \multicolumn{4}{|c|}{ Activities } \\
\hline & Borrow & $\begin{array}{l}\text { Plant } \\
\text { coffee }\end{array}$ & $\begin{array}{l}\text { Destroy } \\
\text { coffee }\end{array}$ & $\begin{array}{l}\text { Transfer } \\
\text { fixed costs }\end{array}$ \\
\hline Profit & -6.0 & $-\quad 300.0$ & -60.0 & -100.0 \\
\hline Investment & -1.0 & 104.0 & 6.0 & 0 \\
\hline Interest change & -1.0 & 0 & 0 & 0 \\
\hline Operating capital & 0 & $2,108.4$ & 600.0 & 0 \\
\hline Coffee land maximum & 0 & -1.0 & 1.0 & 0 \\
\hline Coffee land minimum & 0 & 0 & -1.0 & 0 \\
\hline Existing coffee & 0 & 0 & 1.0 & 0 \\
\hline Removal paymerit & 0 & $-9,999.0$ & 1.0 & 0 \\
\hline Fixed expenditures & 0 & 0 & 0 & 1.0 \\
\hline
\end{tabular}


Coefficients for moving family workers and permanent employees to off-farm employmerit, all areas

Labor movement activities

Family

Employees

All labor:

january

February

March

April

May

June:

july

August

September

nctober

November

December

Family labor:

January

February

Novembar

Deceniber

Supervision:

\section{jenuary \\ Febiuary \\ March \\ Apri i \\ May \\ June \\ Ju!y \\ Auguest \\ Septenter \\ october \\ bovenjer \\ December}

Family men

llen Empioyed

off-Tarm pay

Reduced labor

Reduced labor cost (Acosta)
156.0

144.0

162.0

150.0

162.9

156.0

162.0

150.0

150.0

162.0

150.0

120.0

156.0

144.0

150.0

120.0

312.0

288.0

324.0

300.0

324.0

312.0

324.0

300.0

300.0

324.0

300.0

240.0

1.0

0

$3,116.0$

0

0
156.0

144.0

162.0

150.0

162.0

156.0

162.0

150.0

150.0

162.0

150.0

120.0

0

0

0

0

312.0

288.0

324.0

300.0

32 \%. 0

312.0

324.0

300.0

300.0

324.0

300.0

240.0

0

i. 0

0

$2,208.0$

$1,520.0$

a!l other areas except Acosta. 
Coefficients of right-hand-side constraints, farms 1 through 4 , Palmares-San Ramón

\begin{tabular}{|c|c|c|c|c|}
\hline \multirow{2}{*}{ itein } & \multicolumn{4}{|c|}{ Farms } \\
\hline & 1 & 2 & 3 & 4 \\
\hline \multicolumn{5}{|l|}{ Labor: } \\
\hline January & 936.00 & $1,560.0$ & $1,404.0$ & $1,560.0$ \\
\hline February & 864.0 & $1,440.0$ & $1,296.0$ & $1,440.0$ \\
\hline March & 580.0 & $1,390.0$ & $1,458.0$ & $1,066.0$ \\
\hline April & $5 \div 0.0$ & $1,290.0$ & $1,350.0$ & $1,990.0$ \\
\hline May & 580.0 & $1,390.0$ & $1,458.0$ & $1,066.0$ \\
\hline June & 560.0 & $1,340.0$ & $1,404.0$ & $1,058.0$ \\
\hline July & 580.0 & $1=390.0$ & $1,458.0$ & $1,066.0$ \\
\hline August & 540.0 & $1,290.0$ & $1,350.0$ & 990.0 \\
\hline September & 540.0 & $1,290.0$ & $1,350.0$ & 990.0 \\
\hline October & 580.0 & $1,390.0$ & $1,458.0$ & $1,066.0$ \\
\hline November & 735.0 & $1,390.0$ & $1,350.0$ & $1,360.0$ \\
\hline December & 720.0 & $1,200.0$ & $1,080.0$ & $1,200.0$ \\
\hline Land, each month & 5.0 & 7.0 & 56.0 & 20.0 \\
\hline Operating capital & $4,400.0$ & $4,000.0$ & $71,100.0$ & $16,900.0$ \\
\hline Burley contract & 2.0 & 0 & 0 & 0 \\
\hline Flue-cured contract & 0 & 0 & 3.0 & 5.0 \\
\hline Potation, castorbeans & 5.0 & 7.0 & 56.0 & 20.0 \\
\hline Rotation, beans & 5.0 & 7.0 & 56.0 & 20.0 \\
\hline \multicolumn{5}{|l|}{ Harvest labor: } \\
\hline January & 624.0 & 624.0 & 0 & $1,348.0$ \\
\hline February & 576.0 & 576.0 & 0 & $1,252.0$ \\
\hline November & 435.0 & 390.0 & 0 & $1,090.0$ \\
\hline December & 480.0 & 480.0 & 0 & 960.0 \\
\hline \multicolumn{5}{|l|}{ Supervision: } \\
\hline January & 624.0 & $2,184.0$ & $4,680.0$ & $1,560.0$ \\
\hline February & 576.0 & $2,016.0$ & $4,320.0$ & $1,440.0$ \\
\hline March. & 648.0 & $2,268.0$ & $4,860.0$ & $1,620.0$ \\
\hline April & 600.0 & $2,100.0$ & $4,500.0$ & $1,500.0$ \\
\hline May & 548.0 & $2,268 . c$ & $4,860.0$ & $1,620,0$ \\
\hline June & 624.0 & $2,184.0$ & $4,680.0$ & $i .560 .0$ \\
\hline Juty & 648.0 & $2,268.0$ & $4,860.0$ & $1,620.0$ \\
\hline August & 600.0 & $2,100.0$ & 4.500 .0 & $1,500.0$ \\
\hline September & 500.0 & 2.100 .0 & $4,500.0$ & 1.500 .0 \\
\hline Octoiver & 648.0 & $2,268.0$ & $4,860.0$ & $1,620.0$ \\
\hline November & 600.0 & $2,100.0$ & $4,500.0$ & $1,500.0$ \\
\hline Deceniber & 480.0 & $1,680.0$ & $3,500.0$ & $i, 200.0$ \\
\hline Fixed expenditures & 61.8 & 166.9 & 601.0 & 143.4 \\
\hline Coffee land maximum & 3.0 & 7.0 & 50.0 & 5.0 \\
\hline Coffee land minimum & 3.0 & 7.0 & 50.0 & 15.0 \\
\hline Fxisting coffee & 3.0 & 7.0 & 50.0 & 15.0 \\
\hline Family men & 1.0 & 2.0 & 0 & 3.0 \\
\hline lien employed & 2.0 & 5.0 & 3.0 & 3.0 \\
\hline Al lotinent of quota & $5 \geq .2$ & 135.0 & 562.5 & 168.7 \\
\hline
\end{tabular}


Coefficients of right-hand-side constraints, farms 5 through 8 , Palmares-San Ramón

\begin{tabular}{|c|c|c|c|c|}
\hline \multirow[b]{2}{*}{1 tem } & \multicolumn{4}{|c|}{ Farms } \\
\hline & 5 & 6 & 7 & 8 \\
\hline \multicolumn{5}{|l|}{ Labor: } \\
\hline January & 624.0 & 624.0 & 312.0 & 624.0 \\
\hline February & 576.0 & 576.0 & 288.0 & 576.0 \\
\hline March & 648.0 & 648.0 & 162.0 & 418.0 \\
\hline April & 600.0 & 600.0 & 150.0 & 390.0 \\
\hline May & 648.0 & 648.0 & 162.0 & $4: 3.0$ \\
\hline June & 624.0 & 624.0 & 156.0 & 404.0 \\
\hline July & 648.0 & 648.0 & 162.0 & 418.0 \\
\hline August & 600.0 & 600.0 & 150.0 & 390.0 \\
\hline september & 600.0 & 600.0 & 150.0 & 390.0 \\
\hline October & 648.0 & 648.0 & 162.0 & 418.0 \\
\hline November & 600.0 & 600.0 & 300.0 & 490.0 \\
\hline December & 480.0 & 480.0 & 240.0 & 480.0 \\
\hline l.and & 10.0 & 4.0 & 6.0 & 2.0 \\
\hline Operating capital & $6,400.0$ & $4,000.0$ & $4,300.0$ & 900.0 \\
\hline Sur-cured contract & 0 & 0 & 1.0 & 0.5 \\
\hline Rotation, castcrbeans & 10.0 & 4.0 & 6.0 & 2.0 \\
\hline Rotation, beans & 10.0 & 4.0 & 6.0 & 2.0 \\
\hline \multicolumn{5}{|l|}{ Havest labor: } \\
\hline January & 312.0 & 0 & 156.0 & 624.0 \\
\hline February & 288.0 & 0 & 144.0 & 576.0 \\
\hline ivovember & 300.0 & 0 & 150.0 & 340.0 \\
\hline December & 240.0 & 0 & 120.0 & 360.0 \\
\hline \multicolumn{5}{|l|}{ Supervision: } \\
\hline January & $1,248.0$ & $1,248.0$ & 624.0 & 624.0 \\
\hline February & $1,152.0$ & $1,152.0$ & 576.0 & 576.0 \\
\hline March & $1,296,0$ & $1,296.0$ & 324.0 & 648.0 \\
\hline Apri! & $1,200.0$ & $1,200.0$ & $=00.0$ & 600.0 \\
\hline May & $1,296.0$ & $1,296.0$ & 324.0 & 648.0 \\
\hline June & $1,248.0$ & $1,248.0$ & 312.0 & $6: 4 \% .0$ \\
\hline Juiy & $1,296.0$ & $1,296.0$ & 324.0 & 543.0 \\
\hline August & $1,200.0$ & $1,200.0$ & 300.0 & 600.0 \\
\hline Septenber & $1,200.0$ & $1,200.0$ & 300.0 & 600.0 \\
\hline Ociober & $1,296.0$ & $1,296.0$ & 324.0 & 643.0 \\
\hline Novimber & $1,200.0$ & $1,200,0$ & 600.0 & 600.0 \\
\hline Decenber & 960.0 & 960.0 & 480.0 & 4.30 .0 \\
\hline Fixea expenditures & 107.3 & 124.8 & 60.0 & 23.8 \\
\hline Coffee land maxinum & 10.0 & 3.7 & 3.0 & 1.0 \\
\hline coffee land minimum & 10.0 & 3.7 & 3.0 & 1.0 \\
\hline Existing coffoe & 10.0 & 3.7 & 3.0 & 1.0 \\
\hline Family men & 2.0 & 0 & 0 & 1.0 \\
\hline Hen employed & 2.0 & $1+.0$ & 1.0 & 1.12 \\
\hline Allotment of quota & $1+2.5$ & 53.4 & 42.7 & $1 i .2$ \\
\hline
\end{tabular}




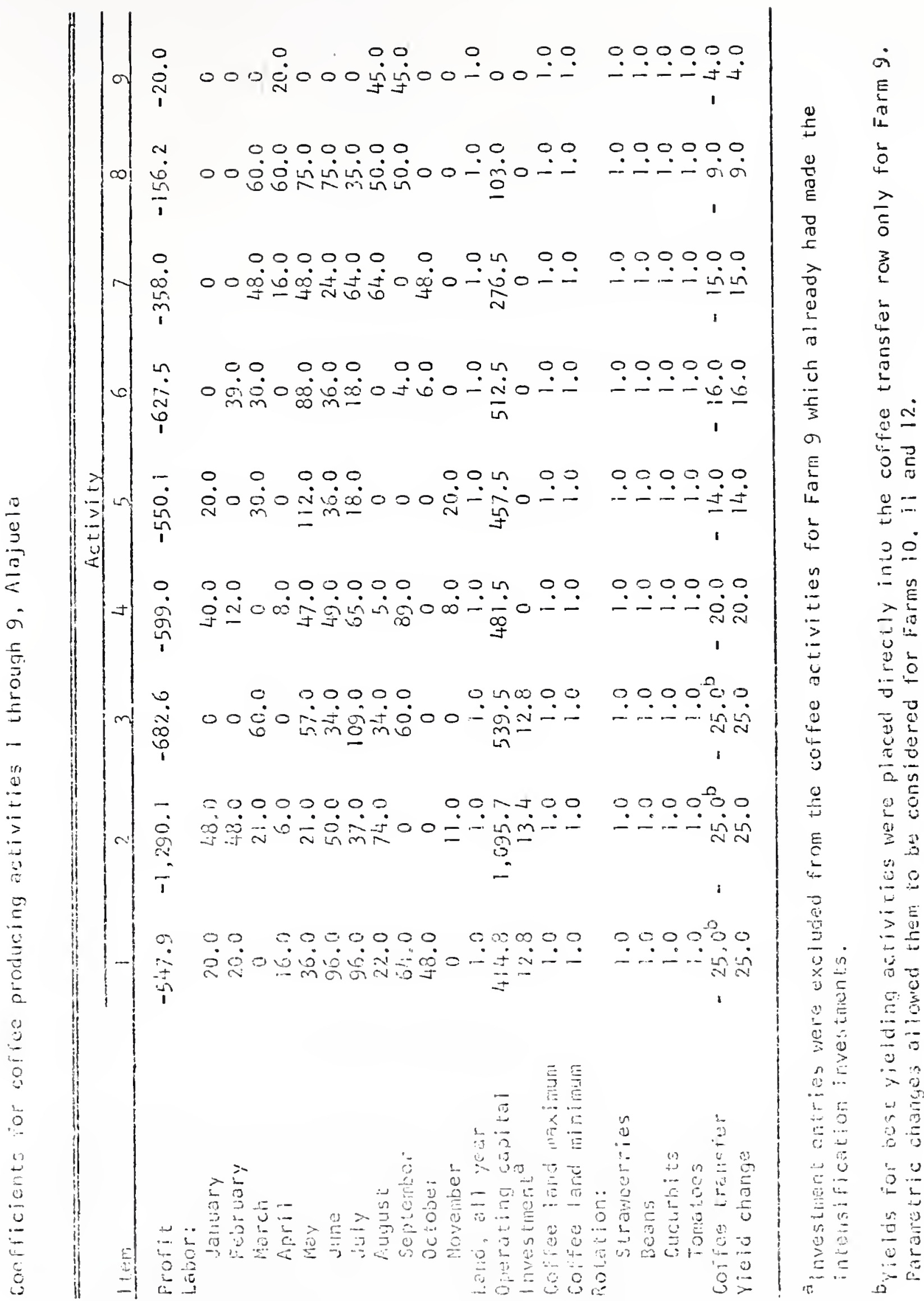


Coefficients for citrus, strawberry and pineapple producing activities, Alajuela

Activity

\begin{tabular}{|c|c|c|c|c|}
\hline Item & Limes & Cranges & $\begin{array}{l}\text { Straw- } \\
\text { berries }\end{array}$ & $\begin{array}{l}\text { Pine- } \\
\text { apples }\end{array}$ \\
\hline $\begin{array}{l}\text { Profit } \\
\text { Labor: }\end{array}$ & \multicolumn{3}{|c|}{ Labor: } & $-5,853.0$ \\
\hline January & 55.0 & 54.0 & 450.0 & 90.0 \\
\hline February & 10.0 & 54.0 & 450.0 & 90.0 \\
\hline March & 10.0 & 14.0 & 450.0 & 450.0 \\
\hline April & 10.0 & 14.0 & 450.0 & 384.0 \\
\hline May & 55.0 & 54.0 & 195.0 & 439.0 \\
\hline June & 55.0 & 54.0 & 195.0 & 234.0 \\
\hline tuly & 71.0 & 62.0 & 195.0 & 372.0 \\
\hline August & 71.0 & 54.0 & 225.0 & 324.0 \\
\hline September & 58.0 & 54.0 & 425.0 & 2.58 .0 \\
\hline October & 10.0 & 14.0 & 395.0 & 228.0 \\
\hline November & 10.0 & 14.0 & 500.0 & 0 \\
\hline Docember & 10.0 & 14.0 & 401.0 & 0 \\
\hline \multicolumn{5}{|l|}{ Laris: } \\
\hline All year & 1.0 & 1.0 & 0 & 4.0 \\
\hline JurenAugust & 0 & 0 & 1.0 & 0 \\
\hline Septamber-May & 0 & 0 & 2.0 & 0 \\
\hline investment & 150.0 & 162.0 & 0 & 0 \\
\hline Operating capital & 450.0 & 249.0 & $6,099.0$ & $4,462.5$ \\
\hline Lire transfer & -400.0 & 0 & 0 & 0 \\
\hline Orange transfer & 0 & $1,020.0$ & 0 & 0 \\
\hline St:anberry transfer & 0 & 0 & 250.0 & 0 \\
\hline fineappie transfer & 0 & כ & 0 & 78.0 \\
\hline Rocation, sqratuturies & 1.0 & 1.0 & 10.0 & 0 \\
\hline Rotation, bears & 1.0 & 1.0 & 0 & 0 \\
\hline Rotation, cucuriats & 1.0 & 1.0 & 0 & 0 \\
\hline Rotation, tombtoes & 1.0 & 1.0 & 0 & 0 \\
\hline Special credit & -450.0 & 7.49 .0 & $-5,000.0$ & $-4.1 .5 ? .5$ \\
\hline
\end{tabular}


Coefficients for corn producing activities, Alajuela

\begin{tabular}{|c|c|c|c|}
\hline \multirow[b]{2}{*}{1 tem } & \multicolumn{3}{|c|}{ Activity } \\
\hline & 1 & 2 & 3 \\
\hline $\begin{array}{l}\text { Profit } \\
\text { Labor: }\end{array}$ & -449.5 & -715.0 & -251.9 \\
\hline January & 0 & 0 & 74.0 \\
\hline February & 0 & 0 & 24.0 \\
\hline March & 0 & 0 & 35.0 \\
\hline April & 272.0 & 4.0 & 0 \\
\hline May & 90.0 & 90.0 & 41.0 \\
\hline June & 93.0 & 98.0 & 41.0 \\
\hline July & 18.0 & 18.0 & 58.0 \\
\hline August & 18.0 & 18.0 & 72.0 \\
\hline September & 0 & 0 & 0 \\
\hline $0 c, t o b \subseteq r$ & 90.0 & 90.0 & 0 \\
\hline No /einber & 0 & 0 & 0 \\
\hline December & 0 & 0 & 0 \\
\hline Land: & & & \\
\hline April-october & 1.0 & 1.0 & 0 \\
\hline All year & 0 & 0 & 1.0 \\
\hline Operating capitál & 351.4 & 551.4 & 149.9 \\
\hline Corn transfer & -80.0 & -90.0 & -60.0 \\
\hline Special credit & -351.4 & -551.4 & .149 .9 \\
\hline Yield increase & -1.0 & -1.0 & 0 \\
\hline
\end{tabular}


Coefficients for bean producing activities, Alajuela

\begin{tabular}{|c|c|c|c|}
\hline \multirow[b]{2}{*}{1 tem } & \multicolumn{3}{|c|}{ Activity } \\
\hline & 1 & 2 & 3 \\
\hline Profit & -521.0 & -60.8 & -139.1 \\
\hline \multicolumn{4}{|l|}{ Labor: } \\
\hline Jantary & 0 & 28.0 & 48.0 \\
\hline April & 4.0 & 0 & 0 \\
\hline May & 2.0 & 0 & 0 \\
\hline June & 92.0 & 0 & 0 \\
\hline July & 51.0 & 0 & 0 \\
\hline August & 65.0 & 0 & 0 \\
\hline September & 51.0 & 22.0 & 72.0 \\
\hline October & 0 & 0 & 0 \\
\hline Decenber & 0 & 60.0 & 72.0 \\
\hline \multicolumn{4}{|l|}{ land: } \\
\hline April-September & 1.0 & 0 & 0 \\
\hline September December & 0 & 1.0 & 1.0 \\
\hline Operating capital & 455.2 & 51.7 & 122.0 \\
\hline Rotation, beans & 1.0 & 1.0 & i. 0 \\
\hline Bean transfer & -20.0 & -5.0 & -10.0 \\
\hline special credit & -455.2 & -51.7 & -122.0 \\
\hline
\end{tabular}


Coefficients for corri and bean, and peanut producing activities, Alajuela

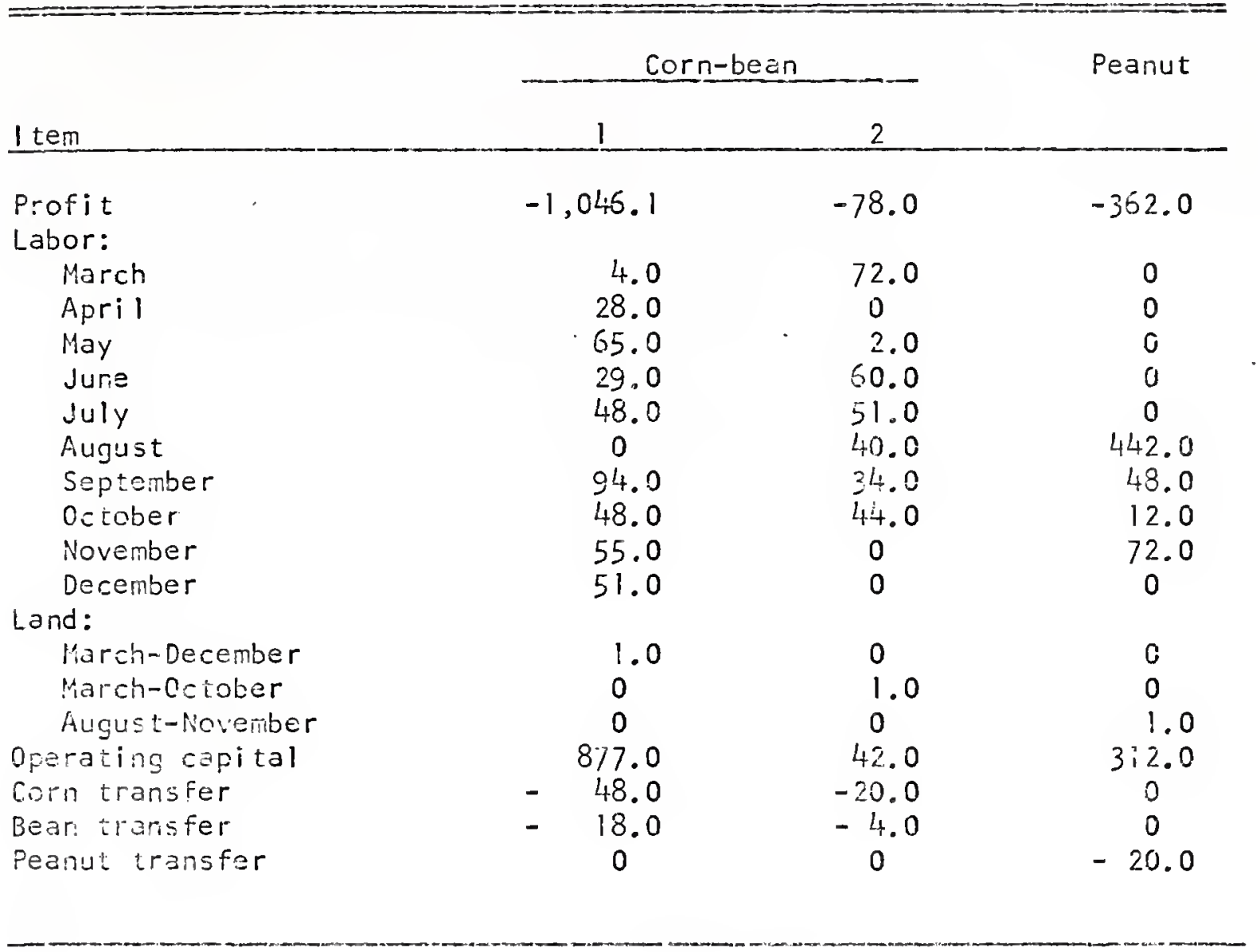




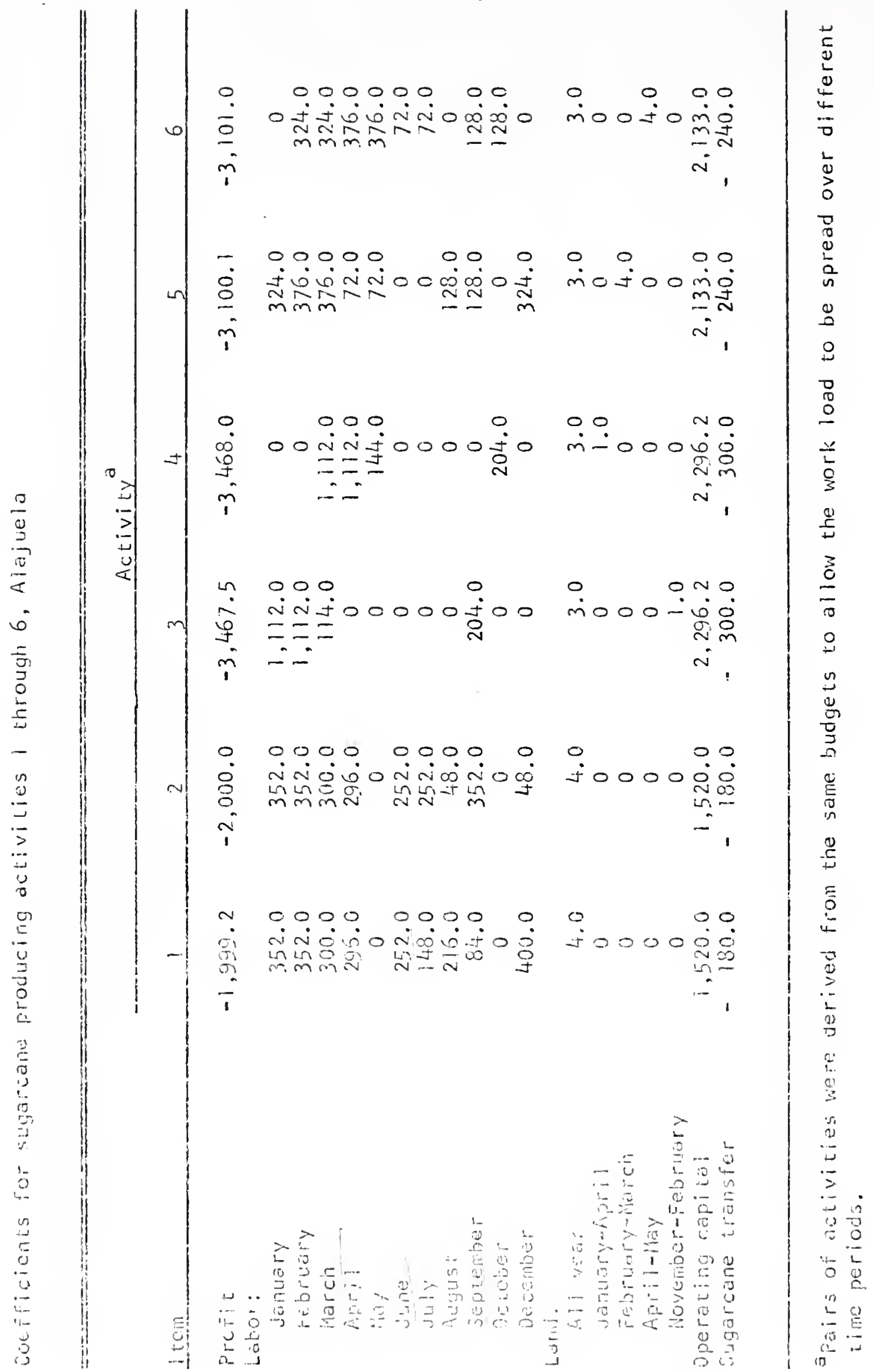


Coefficients for sweetpotato and cassava producing activities, Alajuela

\begin{tabular}{|c|c|c|c|c|c|}
\hline \multirow[b]{2}{*}{1 tem } & \multicolumn{2}{|c|}{ Swee tpotato } & \multicolumn{3}{|c|}{ Cassava } \\
\hline & 1 & 2 & 1 & 2 & 3 \\
\hline $\begin{array}{l}\text { Profit } \\
\text { Lahor: }\end{array}$ & $-1,262.45$ & -346.25 & -669.80 & $-1,277.75$ & $-1,029.00$ \\
\hline February & 0 & 334.00 & 0 & 0 & 0 \\
\hline April & 192.00 & 0 & $i 20.00$ & 0 & 0 \\
\hline May & 116.00 & 0 & 0 & 80.00 & 80.00 \\
\hline June & 104.00 & 0 & 0 & 0 & 198.00 \\
\hline July & 28.00 & 0 & 102.00 & 0 & 0 \\
\hline August & 438.00 & 0 & 0 & 180.00 & 56.00 \\
\hline September & 0 & 0 & 128.00 & 50.00 & 0 \\
\hline October & 0 & 384.00 & 0 & 0 & 80.00 \\
\hline Novembar & 0 & 96.00 & 85.00 & 85.00 & 0 \\
\hline December & 0 & 24.00 & 0 & 0 & 0 \\
\hline Land: & & & & & \\
\hline All year & 0 & 0 & 1.00 & 2.00 & 2.00 \\
\hline 4pri i-August & 1.00 & 0 & 0 & 0 & 0 \\
\hline Cotober-February & 0 & 1.00 & 0 & 0 & 0 \\
\hline August-April & 0 & 0 & 1.00 & 0 & 0 \\
\hline May-june & C & 0 & 0 & 0 & 1.00 \\
\hline Oparating capital & 891.15 & 228.00 & 200.00 & $1,772.00$ & $1,300.00$ \\
\hline Cassava transfer & 0 & 0 & -150.00 & -200.00 & -275.00 \\
\hline Sweetpotato transfer & 300.00 & .100 .00 & 0 & 0 & 0 \\
\hline Special credit & 891.15 & -228.00 & -200.00 & $-1,772.00$ & $-1,300.00$ \\
\hline
\end{tabular}


Coefficients for buckwheat and chickpea producing activities, Alajuela

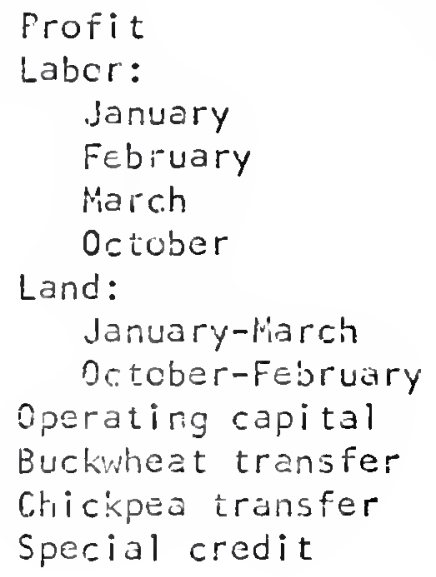

Frofit

Labcr:

January

Febiuary

March

Octuber

Land:

January-March

october-February

Operating capital

Buckwheat transfer

Chickpea transfer

Special credit

$-56.7$

$-82.0$

$$
\begin{gathered}
12.0 \\
0 \\
120.0 \\
0
\end{gathered}
$$

66.0

20.0

0

22.0

$\begin{array}{cc}1.0 & 0 \\ 0 & 1.0 \\ 40.4 & 77.2 \\ -8.0 & 0 \\ 0 & -5.0 \\ -40.4 & -77.2\end{array}$


Coefficients for cucumber and tomato producing activities. Alajuela

Cucuiniber

! téni

Frofit

Labor:

January

February

March

April

Mày

June

July

Augus:

September

October

November

Deceriber

Land:

Harch-May

January-March

May-Oetober

Scpteriber.Fehruary

Operating capital

Rotation, tumatoes

Rotation, cucurtics

Cucumber transfer

Tonato transfer

Spesial credit

$-1,601.2$

1.0

$1,499.2$

0

4.0

140.0

0

$-1,499.2$

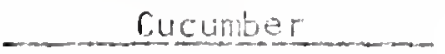

2

$-1,602.0$

$-2,545.0$

$-2,454.0$

Tonato

$\begin{array}{cccc}0 & 350.0 & 592.0 & 0 \\ 0 & 157.0 & 592.0 & 0 \\ 325.0 & 825.0 & 0 & 0 \\ 157.0 & 0 & 0 & 0 \\ 825.0 & 0 & 0 & 102.0 \\ 0 & 0 & 0 & 522.0 \\ 0 & 0 & 0 & 238.0 \\ 0 & 0 & 0 & 279.0 \\ 0 & 0 & 168.0 & 138.0 \\ 0 & 0 & 208.0 & 378.0 \\ 0 & 0 & 390.0 & 120.0 \\ 0 & 0 & 374.0 & 0\end{array}$

$0 \quad 1,0$

$0 \quad 0$

$0 \quad 0$

$1,499.2$

0

i. 0

140.0

.0

$-1,499.2$

C

0

0

i. 0

$1,744.0$

2.0

0

0

-27.7
-1.744 .0

$-1,744.0$

0

0

1.0

0

2

$1,555.0$

2.0

0

0

i1. 2

$-11.2$

$-1.655 .0$ 
Coefficients for swcet pepper, dairy, arid pigeon pea producing activities, Alajusla

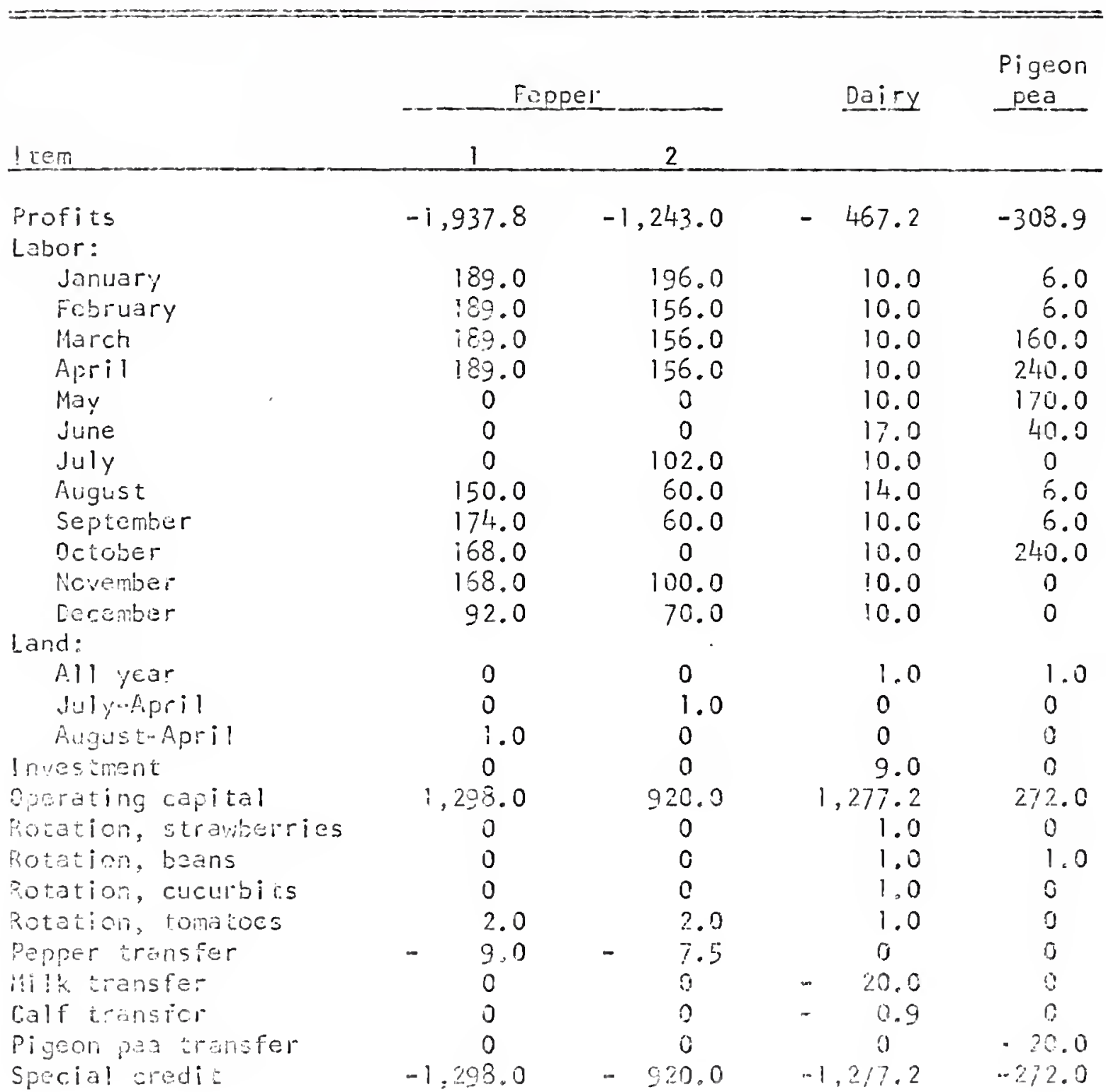




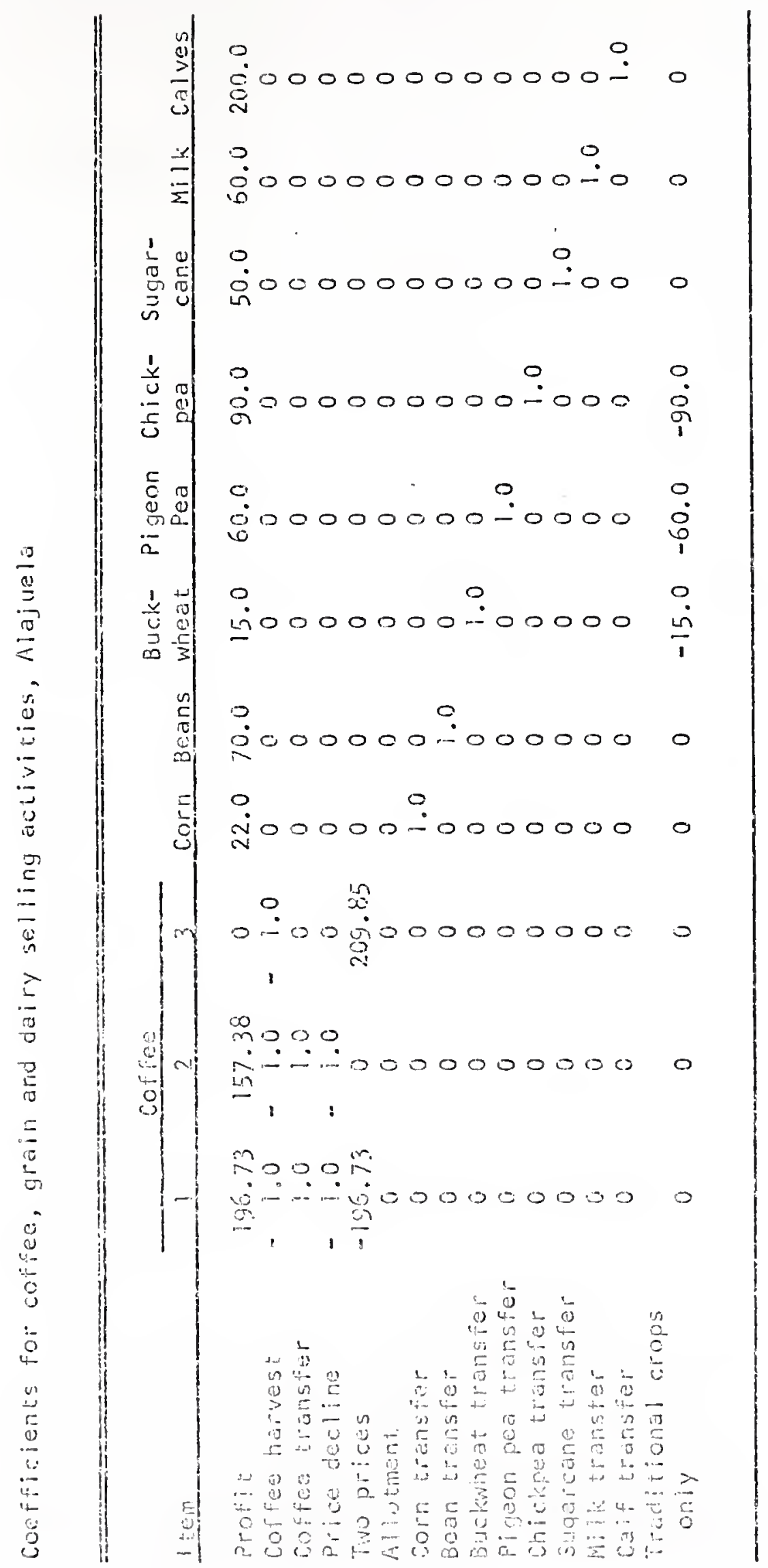




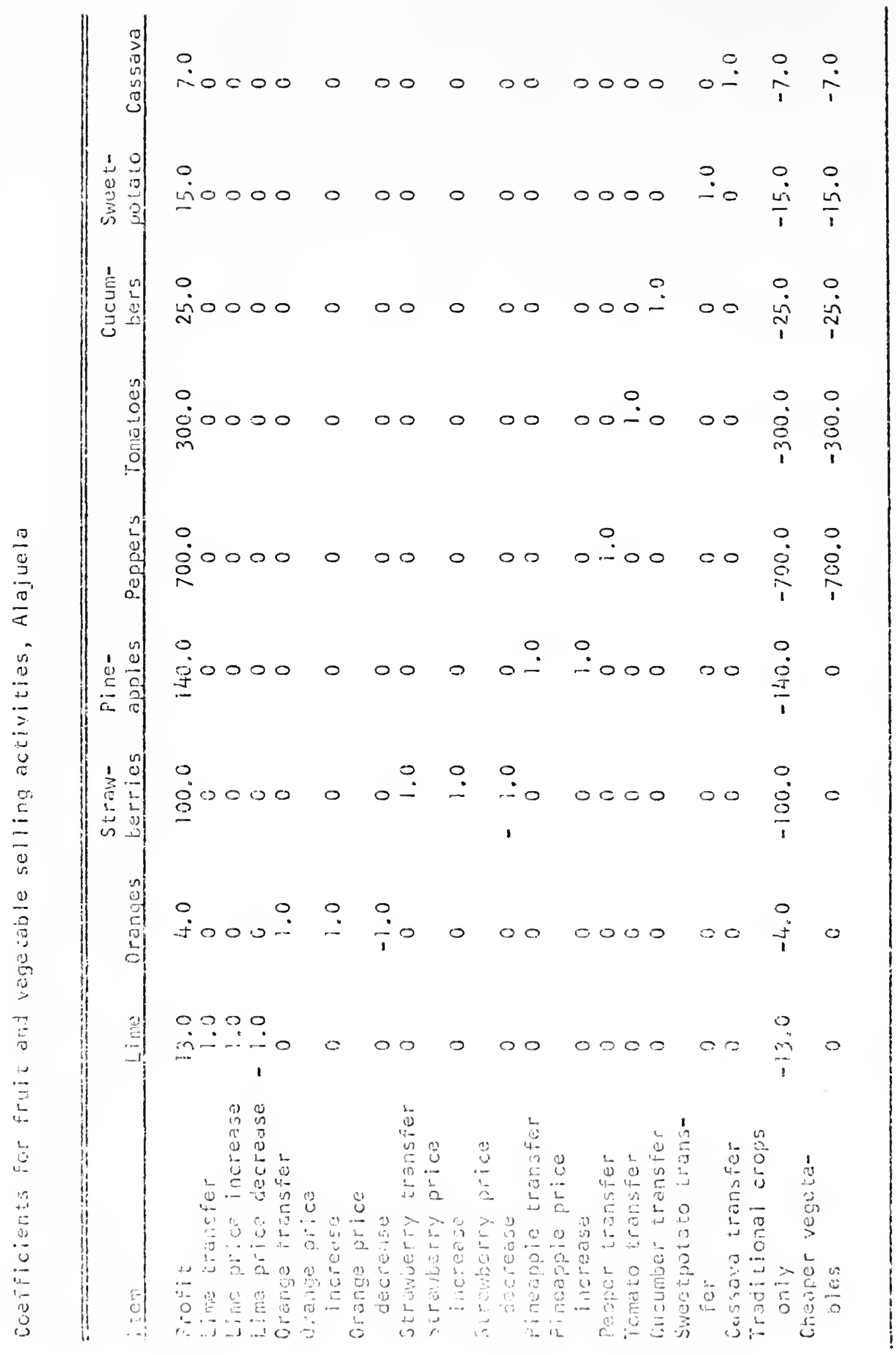


Coffee harvesting activities, Alajuela

\begin{tabular}{lcc}
\hline Ltem & Family & Hired \\
\hline Profit & 0 & -40.0 \\
Labor: & & 0.5 \\
January & 5.0 & 0.5 \\
February & 4.0 & 0.5 \\
liovember & 4.0 & 0.5 \\
December & 5.0 & 0 \\
Harvest labor: & 5.0 & 0 \\
january & 4.0 & 0 \\
February & 4.0 & 0 \\
November & 5.0 & 1.0 \\
Cecenber & 1.0 & \\
Coffe harvest & & \\
\hline
\end{tabular}


Coefficients of right hand side constraints for Alajuela farms

Farms

Item 9

Labor:

Jänuary

February

March

April

May

June

july

August

Scptember

October

Novemiber

December

Laind

Operating capital

Harvest labor, family:

$$
\text { January }
$$

February

Viverriber

Decenter

segrevision of labor:

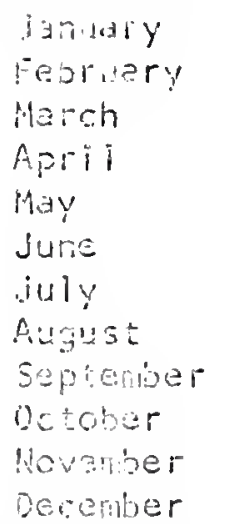

Rotetion, strawberries

Rotation, beans

Rotistion. cuguridis

Posution, toraters

Gixedexpendituros

coîfoe land roximum

cotiec land niarmum

Existing corfere

tosnily bor

Man emploped

Allotint
$2,184.0$

$2,016.0$

$2,025.0$

$i, 875.0$

$2,025.0$

$1,950.0$

$2,025,0$

1.875 .0

$1,875.0$

$2,025.0$

$1,950.0$

$1,630.0$

40.0

22.200 .0

624.0

576.0

450.0

$1+80.0$

$3,7+4.0$

$3,456.0$

$3,888.0$

3,500.0

$3,888.0$

$3,744.0$

$3,888.0$

3.600 .0

$3,600,0$

$3,888.0$

$3,600.0$

2.880 .0

40.0

$\therefore 0.0$

40.3

40.0

$1: 85.7$

40.0

40.0

40.0

$\therefore 0$

10.0

750.0
$1,248.0$

i, 152.0

$1,174.0$

$1,131.0$

$1,174.0$

$1,131.0$

$1,174.0$

$1,087.0$

$1,087.0$

$1,174.0$

$1,125.0$

960.0

15.0

$15,750.0$

458.0

432.0

375.0

उE0.0

$2,184.0$

$2,016.0$

2.268 .0

2.100 .0

$2,263.0$

$2,154.0$

2.268 .0

$2,100.0$

$2,100.0$

$2,268.0$

2.100 .0

1.680 .0

15.1

15.0

15.0

15.0

2:8,

15.0

19.9

15.0

2. 0

5.0

225.0
936.0

834.0

485.0

450.0

486.0

468.0

188.0

4.50 .0

4.50 .0

485.0

750.0

720.0

10.5

$8,850.0$

$1,716.0$

$1,584.0$

$1,296.0$

$1,200.0$

$1,295.0$

$1,248.0$

$1,296.0$

$1,200.0$

$1,200.0$

$1,296.0$

$1,650.0$

$1,320.0$

5.5

$1,115.0$

730.0

$1,404.0$

$720.01,296.0$

$600.01,350.0$

$600.0 \quad 1,080.0$

$62^{\prime}+0 \quad 1,560.0$

$570.0 \quad \div, 440.0$

$648.0 \quad 1,620.0$

$600.0 \quad 1.500 .0$

$648.0 \quad 1.620 .0$

$524.0 \quad \square, 550.0$

$648.0 \quad 1,520.0$

$600.0 \quad 1.500 .0$

$600.0 \quad 1.500 .0$

$548.17 \quad 1,520.0$

$500.0 \quad 1,500.0$

iso.0 1,200.0

$10.5 \quad 5.5$

$10.5 \quad 5.5$

$10.5 \quad 5.5$

$10.5 \quad 5.5$

$96.7 \quad 75.0$

$3.0 \quad 2.5$

$5 . ?$

2.5

2.5

3.0

2.0

i. 0

75.0 
Coefficients of coffee producing activities 1 through 4 , Acosta

\begin{tabular}{|c|c|c|c|c|}
\hline \multirow[b]{2}{*}{ Itein } & \multicolumn{4}{|c|}{ Activity ${ }^{a}$} \\
\hline & 1 & 2 & 3 & 4 \\
\hline $\begin{array}{l}\text { Profit } \\
\text { Labor: }\end{array}$ & -677.00 & -676.35 & -490.00 & -489.40 \\
\hline January & 16.00 & 31.00 & 40.00 & 40.00 \\
\hline February & 15.00 & 68.00 & 10.00 & 10.00 \\
\hline March & 68.00 & 71.00 & 32.00 & 32.00 \\
\hline April & 51.00 & 18.00 & 23.00 & 13.00 \\
\hline May & 38.00 & 18.00 & 21.00 & 31.00 \\
\hline June & 18.00 & 18.00 & 14.00 & 14.00 \\
\hline July & 5É.00 & 73.00 & 57.00 & 114.00 \\
\hline A dgust & 47.00 & 30.00 & 72.00 & 72.00 \\
\hline September & 32.00 & 16.00 & 57.00 & 0 \\
\hline October & 0 & 16.00 & 40.00 & 40.00 \\
\hline Investment & 12.80 & 12.80 & 0 & 0 \\
\hline Operating capitai & 547.75 & 547.75 & $3 ! 5.20$ & 315.20 \\
\hline Land, all year & 1.00 & 1.00 & 1.00 & 1.00 \\
\hline Coffee land maximum & 1.00 & 1.00 & 1.00 & 1.00 \\
\hline Coffee land minimum & 1.00 & 1.00 & 1.00 & 1.00 \\
\hline Coffee transfer & 0 & 0 & -10.00 & -10.00 \\
\hline Yield potential & -14.90 & -14.00 & 0 & 0 \\
\hline Yield charige & 0 & 0 & 10.00 & 10.00 \\
\hline
\end{tabular}

${ }^{3}$ Two activities were derived from each budget to allow flexibility in work schedulirig. 
Coefficients for coifce producing activities 5 through 7, Acosta

Activity

\begin{tabular}{lccc} 
Item & 5 & 6 & 7 \\
\hline Profit & -155.3 & -156.0 & -15.0 \\
Labor: & 40.0 & 40.0 & 0 \\
$\quad$ Harch & 60.0 & 80.0 & 0 \\
$\quad$ April & 64.0 & 44.0 & 0 \\
$\quad$ Jay & 50.0 & 120.0 & 0 \\
$\quad$ August & 70.0 & 0 & 0 \\
$\quad$ September & 0 & 0 & 80.0 \\
Octaber & 100.0 & 100.0 & 0 \\
Operating capital & 116.0 & 116.0 & 0 \\
Land: & & & 1.0 \\
$\quad$ Ail year & 1.0 & 1.0 & 1.0 \\
Cofiee iand maximium & 1.0 & 1.0 & 1.0 \\
Coffee land minimum & 6.0 & -6.0 & -2.0 \\
Coffee tiansfer & 6.0 & 6.0 & 2.0 \\
Yield change & & &
\end{tabular}


Coefficients for coffee-fruit producing activities, Acosta

\begin{tabular}{|c|c|c|}
\hline \multirow[b]{2}{*}{ Item. } & \multicolumn{2}{|c|}{ Activity } \\
\hline & $\begin{array}{c}\text { Coffee-orange- } \\
\text { banana }\end{array}$ & Coffee-orange \\
\hline $\begin{array}{l}\text { Profit } \\
\text { Labor: }\end{array}$ & -459.2 & -300.0 \\
\hline January & 90.0 & 30.0 \\
\hline February & 90.0 & 30.0 \\
\hline March & 90.0 & 40.0 \\
\hline April & 70.0 & 20.0 \\
\hline May & 40.0 & 112.0 \\
\hline June & 10.0 & 0 \\
\hline duly & 60.0 & 0 \\
\hline August & 0 & 120.0 \\
\hline October & 15.0 & 100.0 \\
\hline Lecember & 120.0 & 20.0 \\
\hline Land & 1.0 & 1.0 \\
\hline Cotfes land maximum & 1.0 & 1.0 \\
\hline Coffee iand minimun & 1.0 & 1.0 \\
\hline Coffee transfer & -5.0 & -6.0 \\
\hline Crarge transfer & -10.0 & -30.0 \\
\hline Eanera transter & -1.0 & -0.5 \\
\hline Yield change (coffee) & 5.0 & 6.0 \\
\hline
\end{tabular}


Ccefficients for fruit producing activities, Acosta

Activity

\begin{tabular}{|c|c|c|c|c|}
\hline 1 tem & Orange 1 & Orange 2 & Limes & $\begin{array}{l}\text { Black- } \\
\text { berries }\end{array}$ \\
\hline Profit & $-2,019.6$ & $-1,432.1$ & $-1,767.6$ & $-8,578.7$ \\
\hline $\begin{array}{l}\text { Labor: } \\
\text { January }\end{array}$ & 54.0 & 36.0 & 55.0 & 340.0 \\
\hline Fetruary & 54.0 & 35.0 & $\begin{array}{l}55.0 \\
55.0\end{array}$ & 280.0 \\
\hline March & 14.0 & 0 & 10.0 & 280.0 \\
\hline April & 14.0 & 0 & 10.0 & 180.0 \\
\hline May & 54,0 & 36.0 & 55.0 & 140.0 \\
\hline June & 54.0 & 36.0 & 55.0 & 180.0 \\
\hline July & 62.0 & 32.0 & 71.0 & 180.0 \\
\hline August & 54.0 & 32.0 & 71.0 & 140.0 \\
\hline September & 54.0 & 32.0 & 58.0 & 30.0 \\
\hline October & 14.0 & 0 & 10.0 & 80.0 \\
\hline November & 14.0 & 0 & $i 0.0$ & 140.0 \\
\hline December & 14.0 & 0 & 10.0 & 80.0 \\
\hline Investrent & 162.5 & 58.2 & 150.0 & 0 \\
\hline Operating capital & 249.0 & 155.0 & 450.0 & $3,68 !+0$ \\
\hline Land & 1.0 & 1.0 & 1.0 & 1.0 \\
\hline Orange transfer & $-1,020.0$ & -533.3 & $?$ & כ \\
\hline Lime transfer & 0 & 0 & -100.0 & 0 \\
\hline Blackberry transfer & 0 & 0 & 0 & -150.0 \\
\hline Special credit & -249.0 & -155.0 & -450.0 & $-3,684.0$ \\
\hline
\end{tabular}


Coefficients for corn-bean producing activities, Acosta

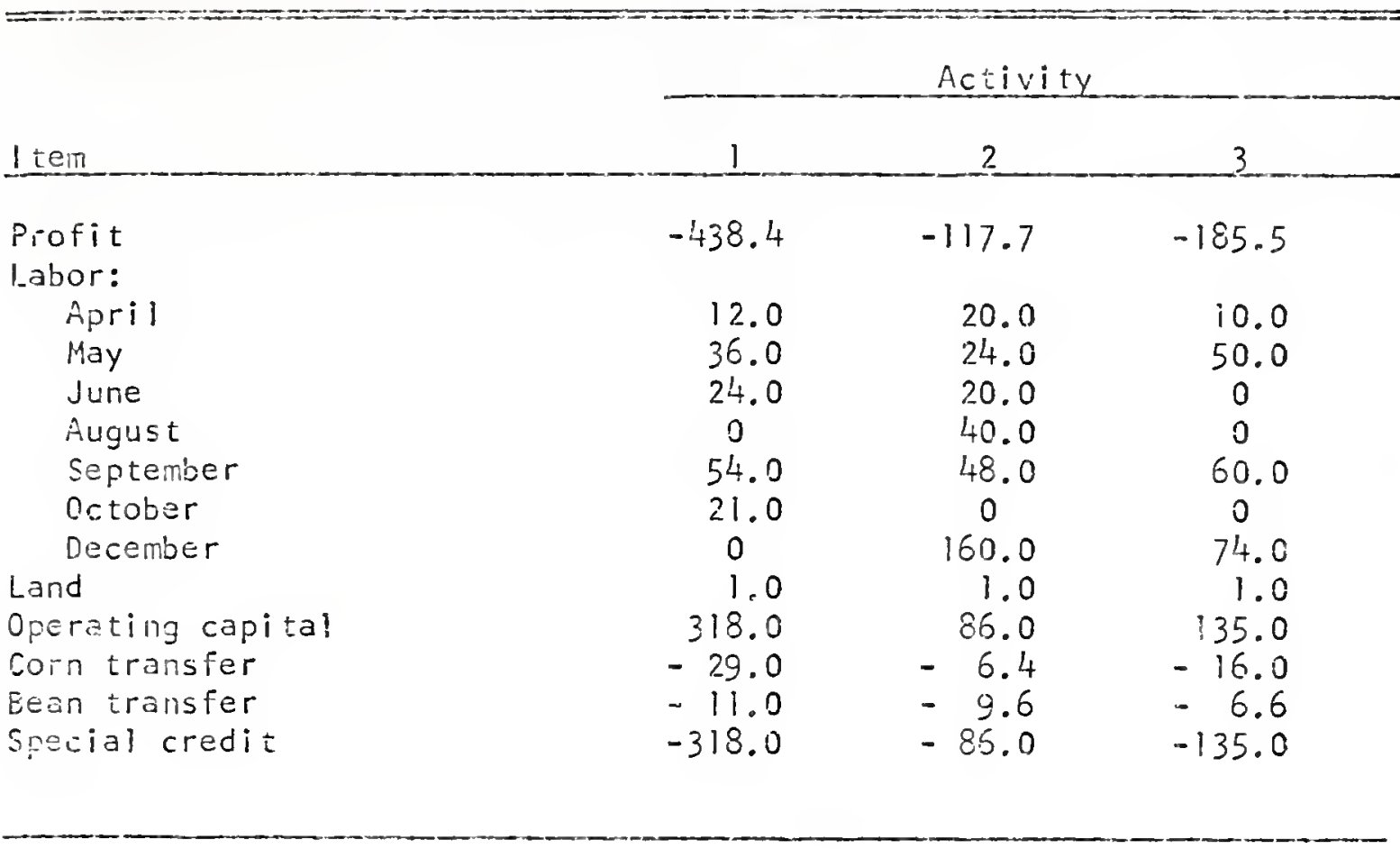


Coefficients for dairy producing activities, Acosta

Activity

\begin{tabular}{|c|c|c|c|c|c|}
\hline Item & 1 & 2 & 3 & 4 & 5 \\
\hline Frofit & -476.9 & -68.7 & -63.0 & -467.2 & -188.2 \\
\hline \multicolumn{6}{|l|}{ Lator: } \\
\hline January & 20.0 & 15.0 & 15.0 & 10.0 & 10.0 \\
\hline February & 20.0 & 15.0 & 15.0 & 10.0 & 10.0 \\
\hline March & 20.0 & 15.0 & 15.0 & 10.0 & 10.0 \\
\hline April & 20.0 & 15.0 & 15.0 & 10.0 & 10.0 \\
\hline May & 20.0 & 15.0 & 15.0 & 10.0 & 10.0 \\
\hline June & 27.0 & 15.0 & 15.0 & 17.0 & 17.0 \\
\hline July & 24.0 & 29.0 & 35.0 & 10.0 & 10.0 \\
\hline August & 24.0 & 29.0 & 35.0 & 14.0 & 14.0 \\
\hline September & 24.0 & 15.0 & 35.0 & 10.0 & 10.0 \\
\hline Cctober & $2 ! .0$ & 15.0 & 15.0 & 10.0 & 10.0 \\
\hline Novemider & 20.0 & 15.0 & 15.0 & 10.0 & 10.0 \\
\hline December & 20.0 & 15.0 & 15.0 & 10.0 & 10.0 \\
\hline Land & 2.5 & 2.5 & 5.0 & 1.0 & 1.0 \\
\hline opcrating capitai & $2,289.9$ & 608.7 & 603.0 & $1,277.2$ & 977.2 \\
\hline investment & 19.0 & 6.0 & 6.0 & 9.0 & 9.0 \\
\hline Milk trarisfer & -30.0 & -10.0 & -10.0 & -20.0 & -10.0 \\
\hline Caif transfer & 0 & 0.9 & 0.8 & 0.5 & -80.0 \\
\hline special credit & $-2,259.9$ & -508.7 & .603 .0 & $-1,2.7 .2$ & -977.2 \\
\hline
\end{tabular}


Coefficicnts for beef producing activities, Acosta

Activity

\begin{tabular}{lrr} 
Item & 1 & 2 \\
\hline $\begin{array}{l}\text { Profit } \\
\text { Labor: }\end{array} \quad-142.0$ & -63.0 \\
$\quad$ January & 5.0 & 1.0 \\
February & 5.0 & 1.0 \\
March & 5.0 & 1.0 \\
April & 5.0 & 1.0 \\
$\quad$ May & 5.0 & 1.0 \\
June & 13.0 & 1.0 \\
July & 13.0 & 34.0 \\
August & 13.0 & 34.0 \\
September & 5.0 & 1.0 \\
Cotober & 5.0 & 1.0 \\
November & 6.0 & 1.0 \\
December & 5.0 & 1.0 \\
Land & 1.5 & 5.0 \\
Investinent & 8.0 & 6.0 \\
Operating capital & 862.0 & 603.0 \\
Calf transfer & 0.7 & 0.5 \\
Spacial credit & -862.0 & -503.0
\end{tabular}




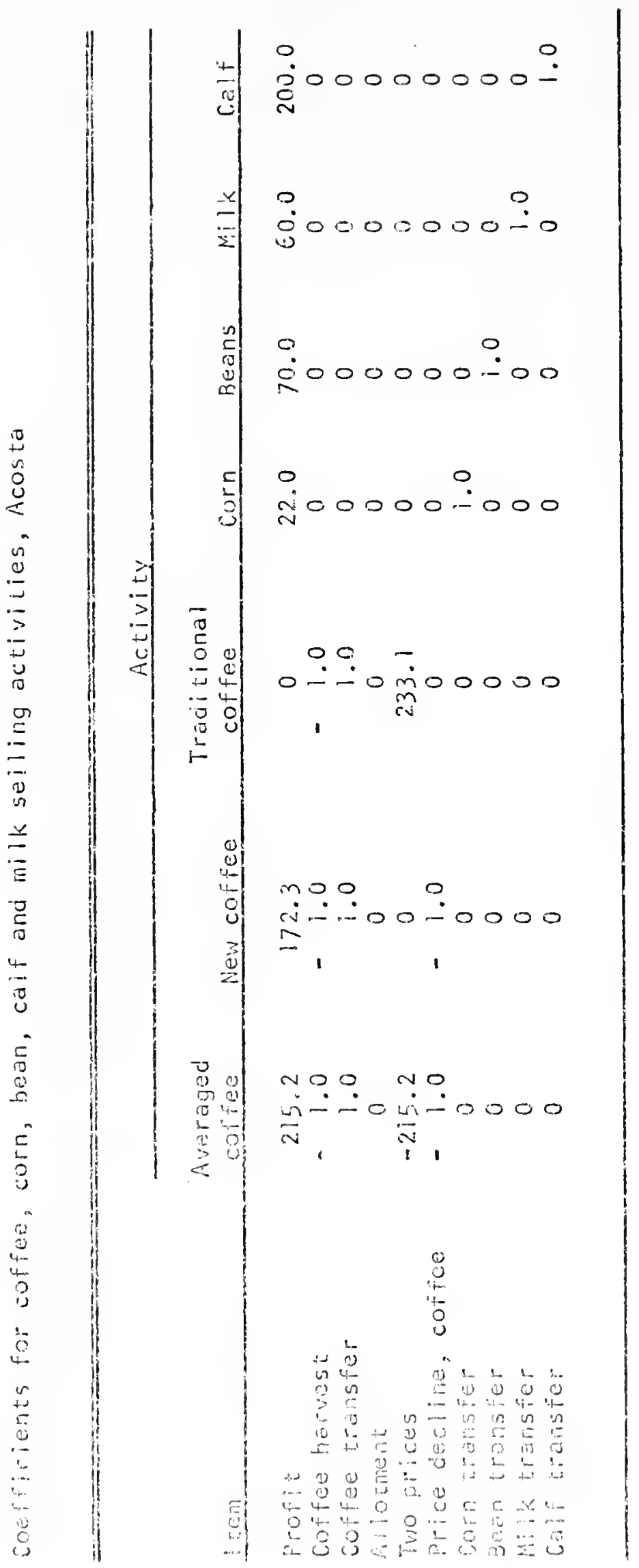




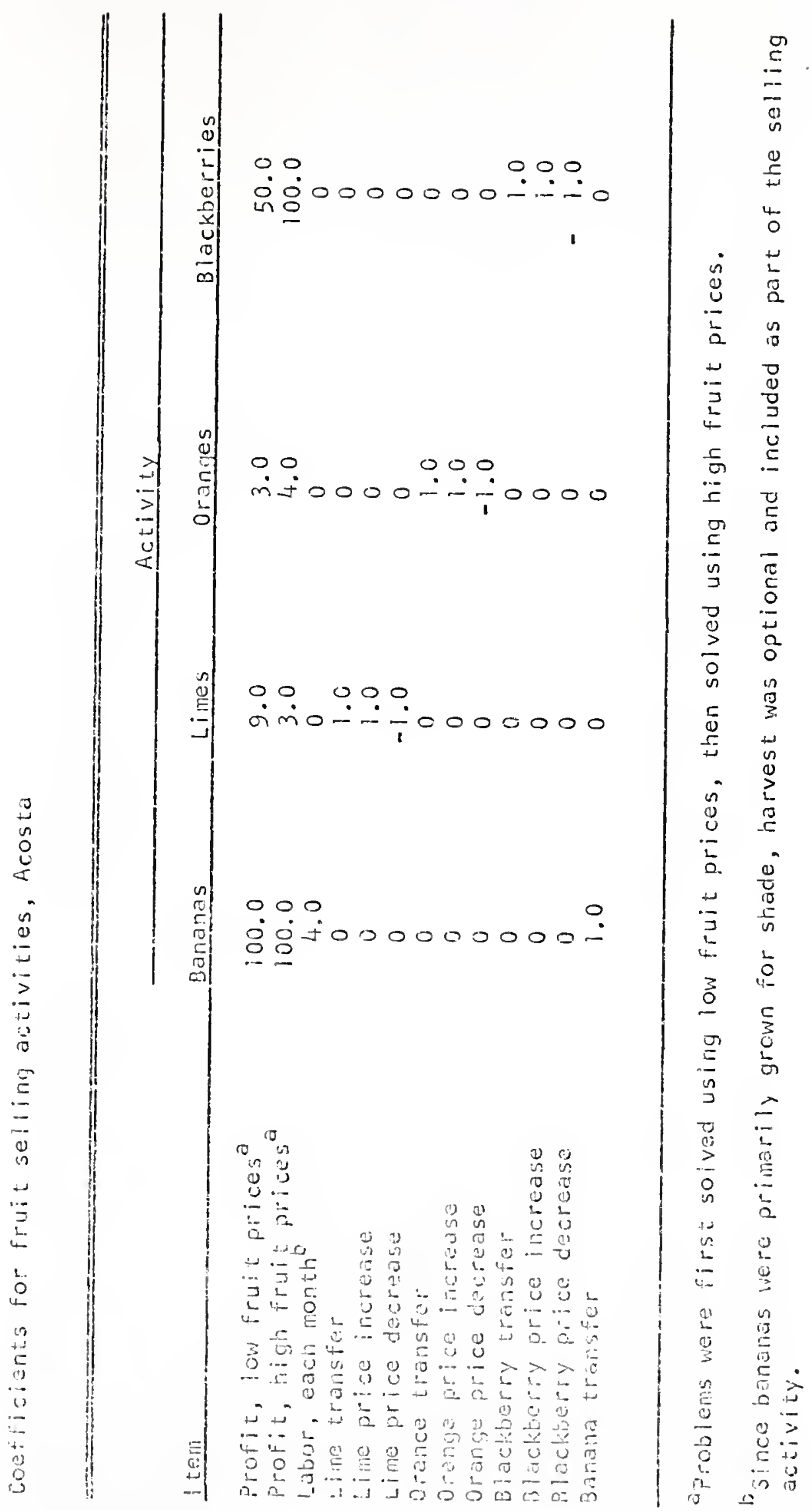


Coefficients for coffee harvesting activities, Acosta

\begin{tabular}{|c|c|c|c|}
\hline \multirow[b]{2}{*}{ tem } & \multicolumn{2}{|c|}{ Harvesting } & \multirow{2}{*}{$\begin{array}{l}\text { October } \\
\text { picking }\end{array}$} \\
\hline & Hired & Family & \\
\hline Profit & -40.0 & 0 & 1.0 \\
\hline \multicolumn{4}{|l|}{ Labor: } \\
\hline January & 0.5 & 5.0 & 0 \\
\hline February & 0.5 & 4.0 & 0 \\
\hline October & 0.5 & 4.0 & 1.0 \\
\hline November & 0.5 & 4.0 & 0 \\
\hline December & 0.5 & 5.0 & 0 \\
\hline \multicolumn{4}{|c|}{ Family harvest labor: } \\
\hline Jenuary & 0 & 5.0 & 0 \\
\hline February & 0 & 4.0 & 0 \\
\hline October & 0 & 4.0 & 0 \\
\hline November & 0 & 4.0 & 0 \\
\hline December & 0 & 5.0 & 0 \\
\hline
\end{tabular}

aThe harvest seasch began ore rionth sarlier in Acosta than in the other two areas; therefore, unused farm labor could be sold in october as weil as in the pericd from November through February inciuded in the tranzfer activicies common to all area matrices. 
Coefficient's of right hand side constraints for farms 13-16, Acosta

Farms

1 tem

13

14

15 16

Labor:

January
February
ilarch
April
May
June
July

$2,808.0$

$2,592.0$

$2,835.0$

$2,625.0$

$2,835.0$

$2,730.0$

August

$2,835.0$

$2,625.0$

September

$2,625.0$

october

$2,916.0$

November

$2,700.0$

Deceriber

$2,100.0$

operating capital

land

$51,422.7$

101.5

Horvest labor, family:

January

February

October

November

December

Supervision of Tabor:

banuary

February

March

April

May

June

july

Airgust

Siptenbe.

ortober

Noverber

Decenber

Fixed expenditures

Fanily men

lien smploved

coffee land maximum.

coffee land niniminn

624.0

576.0

648.0

600.0

480.0

5.304 .0

$4,896.0$

$5,508.0$

$5,100.0$

;, 508.0

$5,304.0$

$5,508.0$

$5,100.0$

$5,100.0$

5.598 .0

$5,100.0$

i. 0850.0

475.0

4.0

9.0

90.0

90.0

90.5

Existing colree

Allotment

675.0

458.0

432.0

486.0

450.0

486.0

468.0

486.0

450.0

450.0

486.0

450.0

360.0

$5,945.0$

16.0

468.0

432.0

486.0

1450.0

360.0

936.0

864.0

$4,72.0$

900.0

972.0

936.0

972.0

900.0

900.0

972.0

900.0

720.0

ii. 5

3.0

0.0

7.0

7.0

7.0

52.5
624.0

576.0

405.0

375.0

1405.0

385.0

405.0

375.0

375.0

648.0

600.0

480.0

825.0

2.0

624.0

576.0

648.0

600.0

480.0

312.0

288.0

$3 ? 4.0$

300.0

324.0

312.0

324.0

300,0

300.0

324.0

300.0

240.0

4.2

1.0

0.0

2.0

2.0

2.0

7.5
624.0

575.0

468.0

450.0

486.0

403.0

486.0

450.0

450.0

648.0

600.0

480.0

675.0

6.5

312.0

288.0

324.0

300.0

240.0

524.0

$5 \% 6.0$

$5+8.0$

$6: 0.0$

648.0

524.0

648.0

600.3

600.0

615.0

603.0

480,0

29.9

i. 0

1.0

1. 5

i. 5

1.5

5.6 


\section{LITERATURE CITED}

1. Abercrombie, K. C. "Population Growth and Agricultural Development." Montily Eullesin of Agriculturel Economics and Statistics, $18(4): 1$. 8 . Apri i, 1967.

2. Acosta, Rogelio and Rodrigo Cieves. Tipos de Café de Costa Rica. Boletín Tócnico No. I, Oficina del Café San José, Costa Rica: 1964.

3. Alleger, Caniel E. "Agriculturai Economics," pp. 26-50. Fertile lands of Friendship, ed. D. Alleger. Cainesvilie, Florida: The Iniversity of Florida Press, 1962.

4. Anker Ladefoged, A. V. Sicultivation of Buckwheat on Up-Country Patonas:: Trepice? Aariculturist, 108 (4): 269-270. 1952.

5. Armijo Pujoi, aiberto. Estudios de Eveluación. Rendimiento Total, Comercia! No Comercia! y Foliaje de variedades de finote (1mponoce batatas 1.) Enfluences de :as listancias de siembra

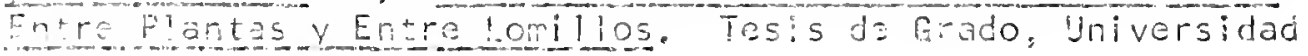

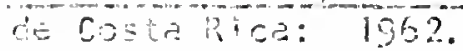

6. Asociation Hacional del Café. Prograna de Diversificación ce ANACAFE, Giateriala: 1957 .

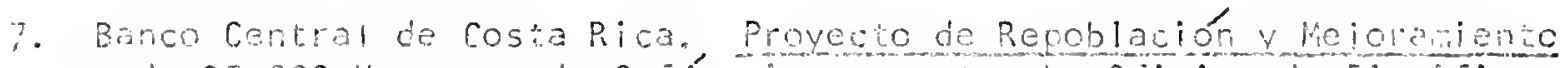
dE 35,900 Manzenas de Café A report to tre oploine da Flanificarizu, rrecijencia de ia Repubiica. San josé: 1955.

3. Parroys oversas Suvey 1068. Lurdon: Barolays Eank, ly68.

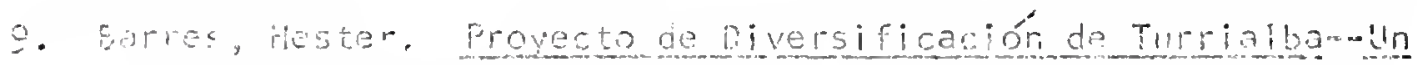

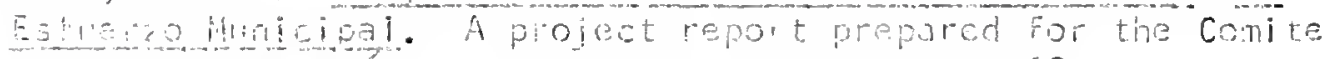

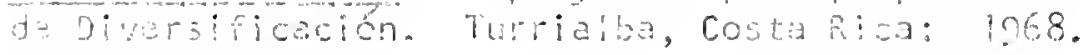

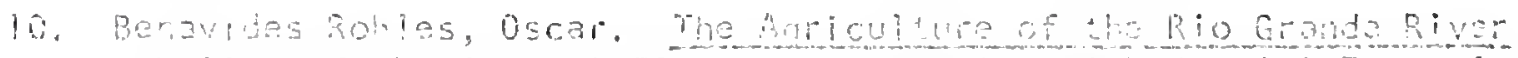

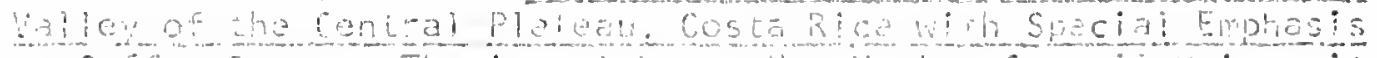

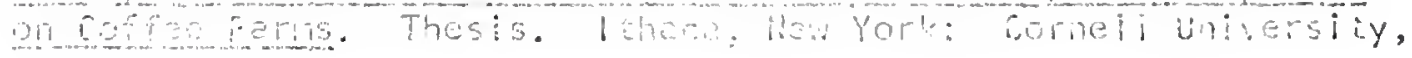
$195 \%$

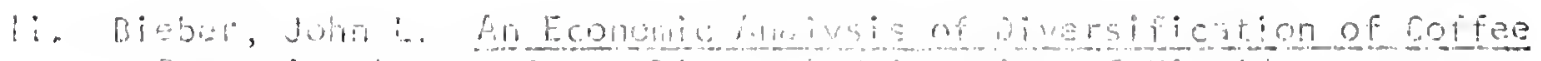

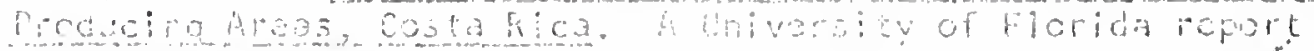

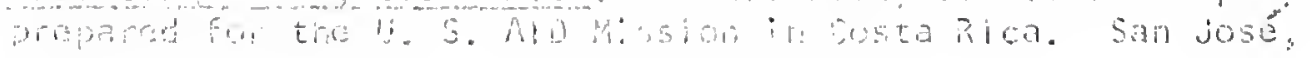
coste ifica: is68. 
12. Erooke, D. L. and R. L. Qua!ls. Production and Me-keting of Eloride Strawberries. Sigricultural Econonics Mimeo Report EC 67-3. Getaber, 1966.

13. Erown, Lester F. "The World Food and Population Probien." Foreian Agriculture, $5(5)$ : 3-4. January 30. 1967.

14. Caro Costas, Ruben, Jose Vincente Chandler, and Jacinto Figarella. "Productivity of Intensively Maraged Pastures of Five Erasses on Steep Slopes of Humid hountains of Fuerto Rico." Journal of Aariculture of the University of Puerto. Ricc, 49 (1): $99-111$.

15. Carvajal, Manuel J. and janes E. Ross. Fact Sheets on Costa 足ean Agriculture. A University of floride report prepared in conperatiol with the U. S. Ald Mission in Costa Rira. San Josés Costi Rica: 1358.

16. Castillo, Carlos M. Growth and integrazion in Contrel America. New York: FrederickA. Praeger, Publishers, 1966.

17. Castro, duar J, and jumes E. Ross. Factors fffecting Arphusiness Investmert in Costa Risa. A University of Florida report prepared in cooperation with the U. S. AlO Mission in Costa Rica. San José, Costa Rica: ig69.

18. Collaco, Oscar. "Costo Fronedio de Producción por Mianzaná de Cultivo." Work Sheets of Sesción de juntas Rurajes je crédito Agrícola, Depertmento de Crédito Rurai, Banco llacicnal de Costa Rica. 1967.

9. Consejo Superior Universario. ofretav Demande de Recursos Humanos en Cencroamerica. Estudio do Recursos Humanos on Conernamerica Mo.6. Ciudad Universitaria, CostäRica: 1966.

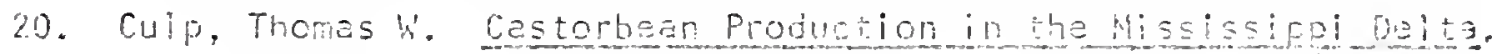
Mississippi Agriclitural Experinent Stesion euiletin 6775. 1963.

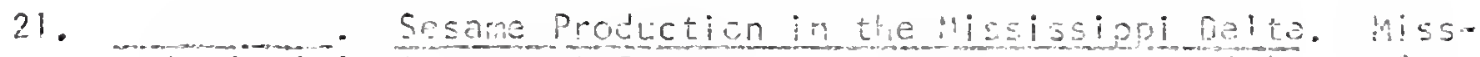

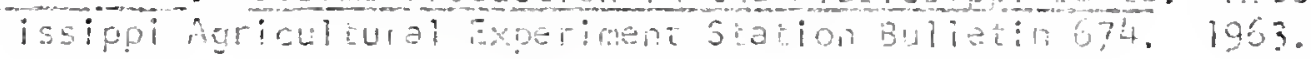

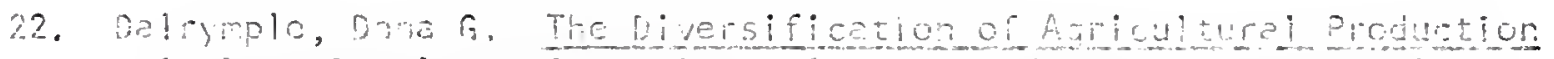

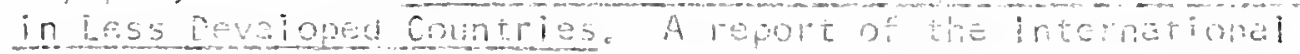

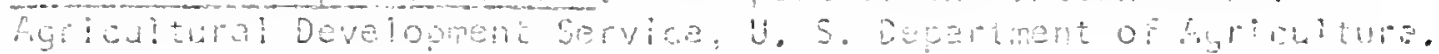
irashingrur: lgis.

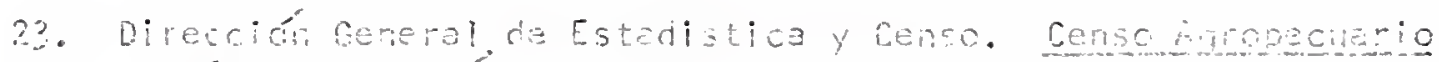
!ofa. San losé. Cosia Rica.

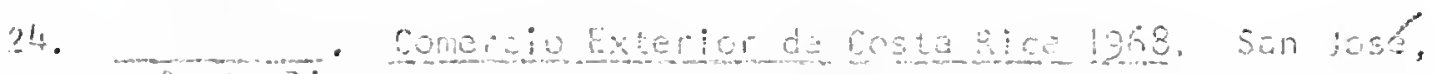
Costarica.

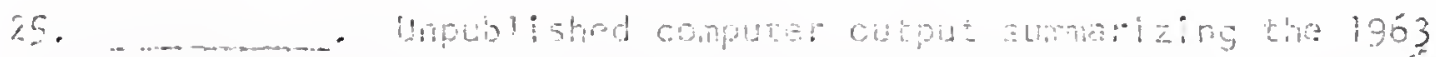
agriouttura! consus by district fur majü creps. San josé. costatis ica. 
26. Facuitad de Agronomía. Informe de Trabajo Anexo de licrticultura, Estación Exórimental Aarícola "Fabic Baudrit Moreno." A report of the universidad de Costa Rica. 1953.

27. Fernandez, Cailos Enrique. Mdapteción de la Producción Latin. anericana de Café a la Demanda Mundal." Revista Cafetaiera. octubre de $1967,23-31$.

28. Floridz nepriment of hgricuiture. írus Sumary. Elerida Aariclitural Stetistics. 1966.

29. Food and Agriculture Organization. "Coffee Production." 19onthly Euiletin of Agricu!ture and Statistics, 17 (11): 21 . Hovember, 7568.

30. Gilbert, Alvin E. "Coffee in Latin Ameriga: A Blessing and a Burden." Foreian Agriculture, 5 (15): 10. April 10, 1967.

31. Gooding, H. 2. "The Agromomic Aspects of Pigeon reas." Field Crop Abstracts, $15(10): 1-5 . \quad 1962$.

32. Haarer. A. E. Hodern Coffee Production. London: Leorard Hill Limited, 1962.

33. Heady, Earl 0. and Wiltred Candler. Linear Frogramina Methods. Ames, iowa: The lowa State University Press. 1958.

34. Internationa! coffee Agreement. 1968. World Coffce Information conter. Wasingtor. "Diversification Fund" Chader XVI, friticie 5it.

35. "Hsae? Exfands Strawberry Market." Foroign Agrigulture, 7 (33): i6. Septonter 27, 1969.

36. Junta de Dérensa del Tabaco. Investigarión soble producéón e jnipesos de iabace. San jose, costafira: 1967.

3\%. Kennen, Peter B. Incernatinnal Ecomonics. Fuglewood biffs, Ron jersey: Prentice inli, linc. 1964.

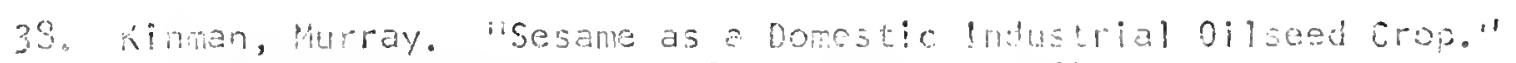

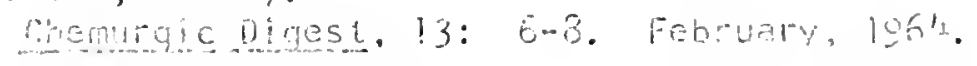

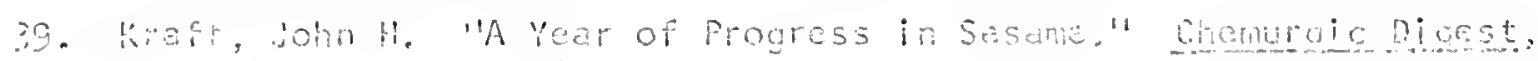
$17: 4$. April, 1958.

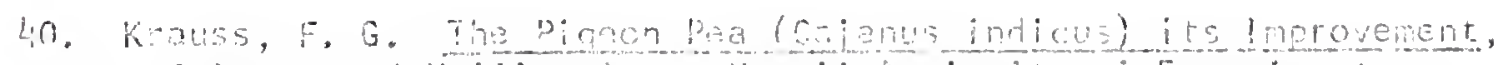

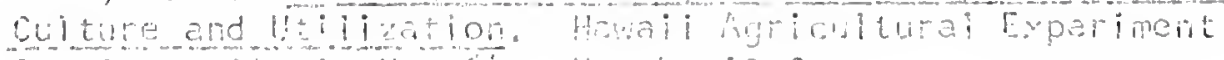

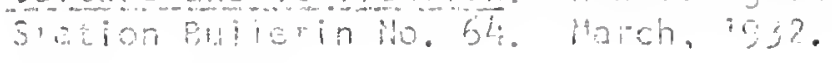

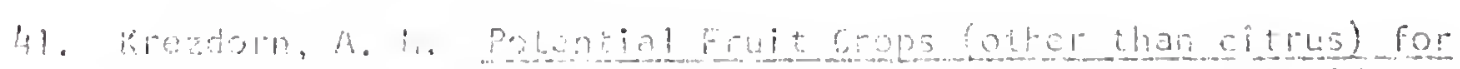

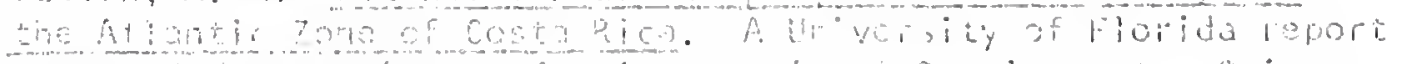

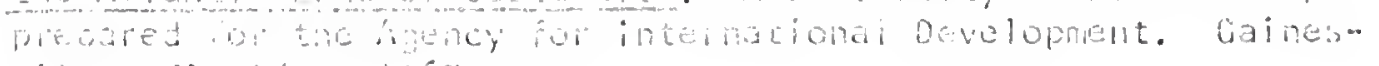

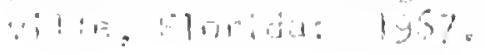


42. Krome, Wi ilizm H. "Economic View of Lime Growing in Florida." Ecoromi: Botany, 22 (3): 270-272. July-September, 1958.

43. Lanser, Paul. "Plastic Mulching is a Profitable Practice." American Eruit Grower, 87 (3): 30-32. March, 1967.

44. Leftwich, Richard it. The Price System and Resource Allocation. New York: Holt, Rinehart and Winston, 1966.

45. Lodkey, Liwrence C. A Guide to Market Cata in Central America. Eank for Economic Integration, Tegucigalpa, Honduras, 1964.

45. Hagleby, R. S. "Agricultural Geography; Latin Arrerica in Trarisition," Foreign Agriculture, 5 (15): 11. April 10, 1967.

47. Martin, john H. and Waren H. Leonard Princip?es of Field Crop Production. New York: The Macmillan Company, 1949.

48. Milliken, Max F. and pavid Hapgood. No Easy fiarvest. Boston: Little, Brown and compary, ig67.

49. Ministerio de Agricultura de Guatemala Costos de Estabiecimienio, Marcenimiento y Cosecha de los Cultivos de Hule Cacao oisicos, Vanilla, Jocote Maranón, Sova Pina coco, Mango Papaya v Piniento Negra. Fn economic report prepored by itie "Los Ei ilantes" Experiment Center. Mulua, Retalhuleu: 1968.

50. Ministerio de Agricultura y Ganaderia. Cultivos Agrícolas de Costa rica dicrual de Reconendacinos. Brbetin Tecnico Mo. 35. san jase, costakica: 1965.

5i. _........... Mroducción de Frijoles en ia Zona de Atenas-msan Josecito (Aiajusla) Costa pira." Proyecto da lrvestireriones Economicas. F. 36- No. 3. Marzo. 1962 .

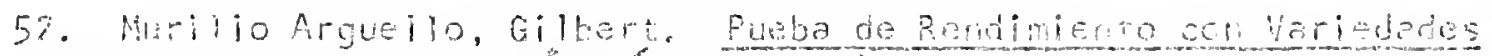

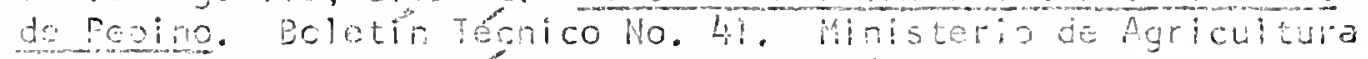
y Ganderia. San josé, Costa Rice: ig6z.

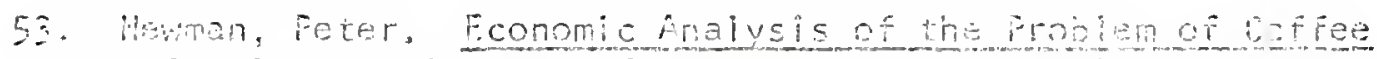

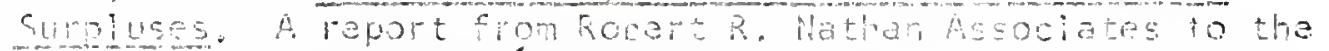

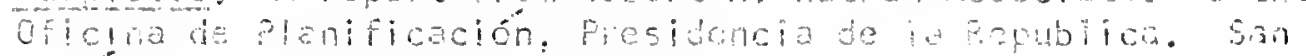
roser: coses Rica: vuly, 1966.

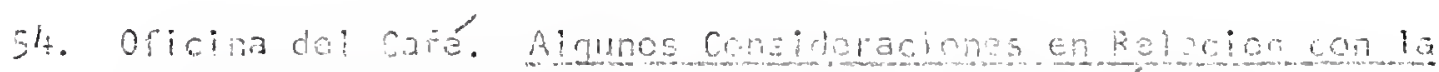

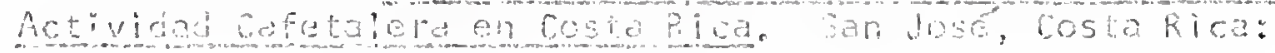
iri67.

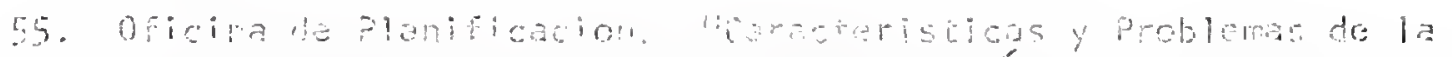

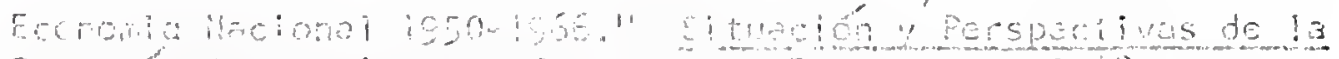

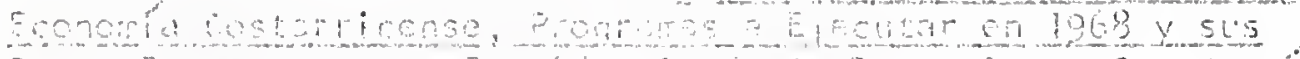

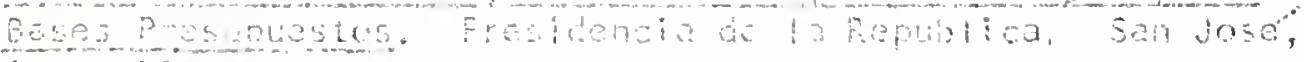
actak 
56. Sector Compendio de cifras Básicas de costa Rica lV. San losé, Costakica.

57. Organization of American States, Fan fmerican Union. Production and Exeort rapabilities for Certain Agricultural Froducts in Sew end Proressed Form in Central America. Washirigton: 1966.

58. Dspino, V. F. Manuel de Costos Sásicos de Actividades Aarooecuaries. Banco de Credito Aigricola de Cartago. San Jose, Costa Rica: 1966.

59. Pan American Coffee Bureau Coffee and the 19. S. Consiger. New York: $i 964$.

60. Pitcher, S. Mrazil's Coffee Tree Eradication Program as of Todiay." Foreion Agriculture, 3 (22): 67. Augist 16, 1965.

61. Scro!l, Join i. "Mexico's Grain Problem: A projuction Ecori That Won"t Turn 0ff." Foreign Agriculture, 5 (27): 7. duy 3, 1967.

62. Schultz, Theodore $W$. Ecomac Crisis in worid Acriculture. Ann Arbor, Michigan: The University of Michigan Press, 1965.

63. ............ Transforming Iraditiongl Agriculture. New Haven, comertirut the rale liniversity fress. 1904.

6\%. Sarvicio Meteorolouico Macional. Boietín Meteorolodico Año 1965. 3en jojé, Gosta Rica.

65. Sharmar. W. B. and P. A. Westgate. Blackberry Production in Elorida. Florida Agriculturai Entension Servica Circular 325. May. 1968.

66. Tollev. G. S. and G. D. Gwver. "Hnternational Trarie in Agicultura! Products in Re?ation to Fcononic Development," Pl. 403-447. Agriculturel Developirent and Economic Brouth. Eds.

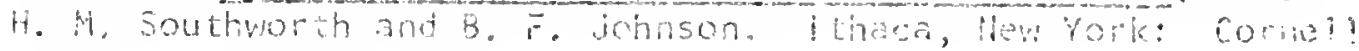
University fress, 1967.

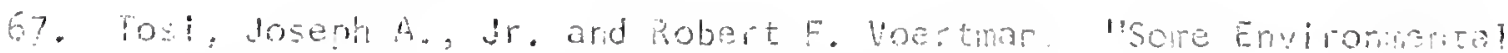
Focrors in the Economic Davelopment of the Tropics." Econorige Eegrapin, so: 189-205. July, 1864.

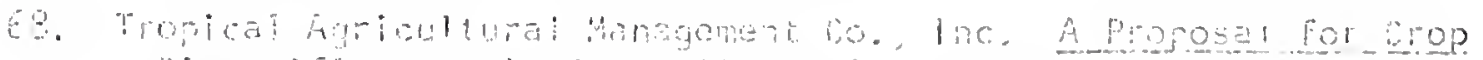

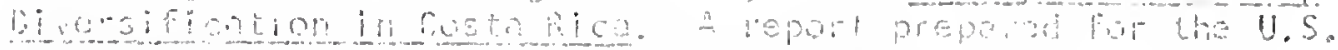

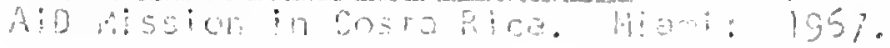

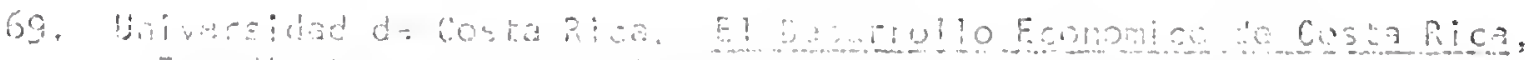

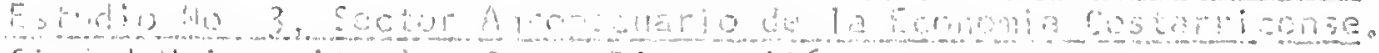

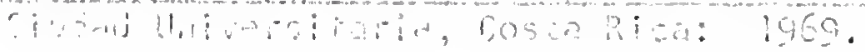


70. Uribe-Ruiz, J., M. E. Aragan and A. T. Viterbo. "Contribution to the Agromonic and Chemica! Study of the Buckuneat (Polygonum Fenopurue) cultivated in Mexico." Revista de Sociedad Quimica Mexicana, $5(4)$ : 129-131. 1961. From Biologicai Abstracts, $41: 24454$.

7!. Vergas Vaglio, Oscor and Joss Alterto Torres, Estudio Preliminar dé Suelos de la Región Occidental de la Meseta Centrai, Boietín TÉcnico io. 2?. M. A, !. San José. CostaRica: 1953.

72. Weiss, E. A. "Dwarf Castor." World Crops, 18 (12): 43-49. December, 1966.

73. Wellman, Frederick l. Coffee: Botany Cultivetion and Utilization. London: Leonäd Hili Limited, 1961.

74. Welton, Richard S. MEl Salvador Plans Crop Diversification to Spur its Economy." Foreign Agriculture, 5 (32): 5-6. August $7,1967$.

75. Wison, Daiton L. "Guatemala-and Its Flourishing Rubter Industiy." Foreign Agriculture. 5 (29): 3-4. July 17, 1967. 


\section{B!DORAPHITAL SKETGH}

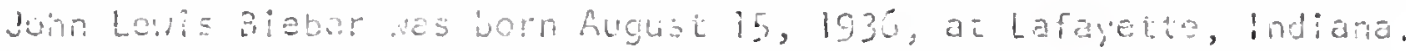
He grew up on a gene"al purpose farm near befayetce and gradueted from

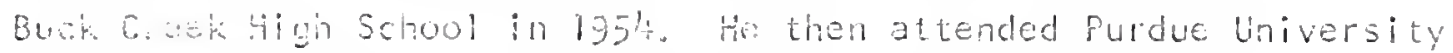
minge to received the degree of Eacholor of science in Agricuiture ir. Jure, 1958, with a major in Agranony.

hic entered the Graduate school of Kansas State bniversity in September, i358, and receivod the degree of Master of Science ir. June, 1960, ith a major in Agronomy and a minor in Agricultural Eamonics.

ir. Biaber served in the United States Air Force. He enterej the Giaduate School of the University of Florida in Jaruary, 19et. He left tro viliversity in May, 1965, and tarned cwo years in indiana. In September, 1966, he returned to the University of Florida and rontinge work soward the degree of loctor of Philosophy in Agricultural Econonics. In July, 1957 , Mr. Bieber began research under the U. J. A:0/ University of florida Contract in Costa fica. He receivad an interin siaff position in November, 1968, with the University of florida in order bo carry out additional investigations of crop diversiticaricn in Costa Pice. In January, 1970, Mr. Bieber again entered the University of Floridu to complete the requirements for the Doctor of Philosophy degree.

Jotn Lewis Bieber is Married to the former Martha Eugenia Stelle. He is a mentur of Gama signa delta. 
This dissertation was prepared under the direcion of the chairmen of the candidate's suparvisory committee and has been approved by all members of thot comittee. It was submilted to the dean of the College of Agriaulure and to the Graduate Council, and was approvef as partial furfiliment of the requirements for the degres of Doctor of $P_{\Gamma}$ i losophy.

March, 1970

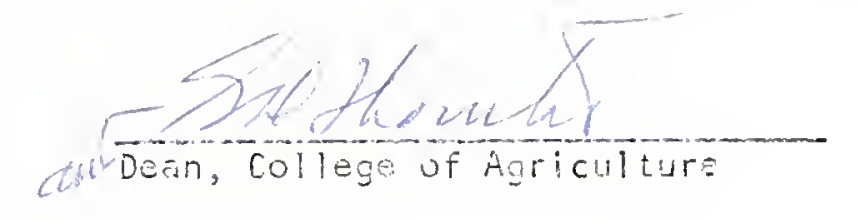

Beri, Groduete schoo

Supervisory fommitree:
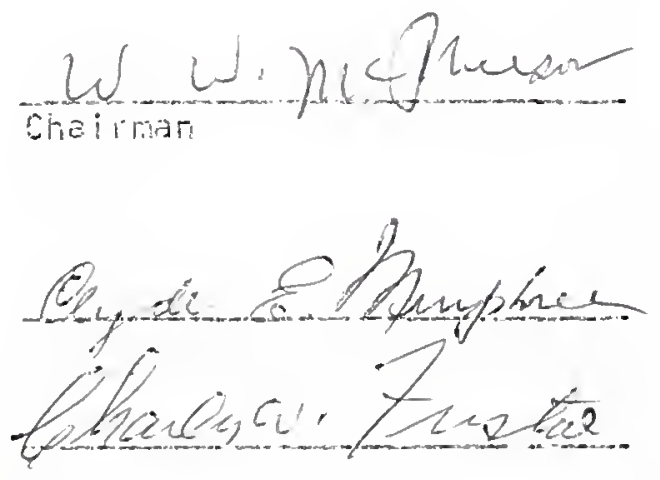


$$
1408-8
$$

